\title{
Thrombus-targeting therapy with apyrase-annexin V fusion attenuates thrombosis without bleeding
}

Ridong Chen ( $\square$ rchen@apt-therapeutics.com )

APT Therapeutics Inc

Dana Abendschein

Washington University

Soon Seog Jeong

APT Therapeutics Inc.

Thomas Wakefield

University of Michigan

Jose Diaz

Vanderbilt University

Karla Bergonzi

Washington University

Monica Shokeen

Washington University

Robert Leadley

Lead Biopharma Consulting

Article

Keywords: antithrombotic therapy, apyrase-annexin $\mathrm{V}$ fusion, thrombosis

Posted Date: June 17th, 2021

DOI: https://doi.org/10.21203/rs.3.rs-514573/v1

License: (c) (i) This work is licensed under a Creative Commons Attribution 4.0 International License.

Read Full License 


\section{Thrombus-targeting therapy with apyrase-annexin $V$ fusion attenuates thrombosis without bleeding}

One-sentence summary: Thrombus-targeted antithrombotic therapy

Authors: Dana Abendschein ${ }^{1 *}$, Soon Seog Jeong ${ }^{2}$, Jose A. Diaz ${ }^{3-4}$, Thomas W. Wakefield ${ }^{3}$, Karla Bergonzi $^{5}$, Monica Shokeen ${ }^{5}$, Robert Leadley ${ }^{6}$, and Ridong Chen ${ }^{2 *}$

\section{Affiliations:}

${ }^{1}$ Center for Cardiovascular Research, Department of Medicine, Washington University

School of Medicine, St. Louis, MO 63110, USA

2

APT Therapeutics Inc., 1701 Quincy Ave, Naperville, IL 60540, USA

${ }^{3}$ Department of Surgery, Section of Vascular Surgery, University of Michigan, Ann Arbor, MI 48109, USA

${ }^{4}$ Division of Surgical Research, Section of Surgical Sciences, Vanderbilt University Medical Center, Nashville TN 37232, USA.

${ }^{5}$ Optical Radiology Lab, Mallinckrodt Institute of Radiology, Washington University School of Medicine, St. Louis, MO 63110, USA

${ }^{6}$ Lead Biopharma Consulting, LLC, 77726 Brass Creek Court, Dexter, MI 48130, USA

*To whom correspondence should be addressed. Email: rchen@apt-therapeutics.com or dabendsc@wustl.edu 


\begin{abstract}
Antithrombotic therapy is essential to prevent thrombotic reocclusion in patients with acute myocardial infarction, stroke, or venous thromboembolism. However, current antithrombotic drugs cause bleeding that limits dose and clinical effectiveness. Previously, we reported that APT102 (AZD3366), a human apyrase optimized to scavenge extracellular ADP and ATP, exhibited potent antiplatelet efficacy without bleeding in experimental myocardial infarction and stroke. Here we describe APT402, an optimized fusion of APT102 and annexin V that uniquely inhibits both platelet and coagulation components of thrombus growth. APT402 preferentially bound to injured vessels and thrombus and prevented thrombotic occlusion in arterial and venous thrombosis models, without increasing bleeding. Thus, APT402 breaks the confounding link between antithrombotic efficacy and bleeding, pioneering a safe and effective approach to prevent and treat a broad range of thrombotic diseases, and may be particularly useful in clinical conditions associated with high bleeding risks.
\end{abstract}


Acute myocardial infarction (AMI) and acute ischemic stroke (AIS) result from lifethreatening, thrombus-driven blockages of the coronary or cerebral arteries in which activated platelets and thrombin both play critical roles $(1,2)$. The goals of treatment are to expedite restoration of blood flow and thereby maximize salvage of ischemic myocardium or brain penumbra (1-4). Percutaneous coronary intervention (PCI) is the preferred reperfusion approach after AMI, while fibrinolysis with recombinant tissue plasminogen activator (rt-PA) and/or thrombectomy are the approved treatments for AIS $(1,4,5,6)$. Adjunctive antithrombotic treatment with dual antiplatelet therapy (aspirin and a $\mathrm{P}_{2} \mathrm{Y}_{12}$ antagonist) plus an anticoagulant (heparin or bivalirudin, Angiomax ${ }^{\circledR}$ ) to inhibit thrombin activity is the standard-of-care for PCI patients (7), but none of the currently available antithrombotic drugs can be given during AIS treatment with rt-PA due to the high risk of devastating intracranial hemorrhage (4).

Despite aggressive antithrombotic therapy after AMI, reocclusion from recurrent thrombosis and dose-limiting bleeding occur in a significant number of patients $(7,8)$. Attempts to further improve clinical outcomes have led to the development of more potent platelet $\mathrm{P}_{2} \mathrm{Y}_{12}$ inhibitors including prasugrel $\left(\right.$ Effient $\left.{ }^{\circledR}\right)$ and ticagrelor $($ Brilinta $\AA$, 8-11), as well as direct factor Xa (FXa) inhibitors, rivaroxaban (Xarelto $\left.{ }^{\circledR}\right)$ and apixaban (Eliquis $\left.{ }^{\circledR}\right)(12,13$, not approved for PCI ), but these agents also increase bleeding. Currently, net adverse composite endpoints of death, coronary reocclusion, or secondary stroke remain as high as $7-12 \%$ for PCI and $10-12 \%$ for fibrinolysis, with rates of major bleeding of 5-11\% (9-11). Importantly, most adverse events occur within the first 6-9 hours after intervention. Major bleeding within 48 hours of PCI is associated with a one-year mortality of $7.2 \%$ compared to $2.1 \%$ in patients who do not have periprocedural major bleeding (14). Due to its narrow time-window of up to 4.5 hours postsymptoms and 6- to 7 - 
fold increased risk of intracranial hemorrhage, only $3-5 \%$ of AIS patients receive rt-PA therapy $(4,15)$.

Deep vein thrombosis (DVT) is associated with a high risk of pulmonary embolism that affects up to 900,000 patients annually, with greater than $30 \%$ mortality in the US (16). An historical pharmacological standard-of-care for both treatment and prophylaxis of DVT has included initial administration of low-molecular-weight heparin (enoxaparin, Lovenox ${ }^{\circledR}$ ) with subsequent transition to long-term oral vitamin K antagonist therapy (warfarin, Coumadin ${ }^{\circledR}$ ) (17). Over the past few years, several new direct, selective oral drugs have become available, including dabigatran etexilate $\left(\operatorname{Pradaxa}{ }^{\circledR}\right)$ that inhibits thrombin; and rivaroxaban $\left(\right.$ Xarelto $\left.{ }^{\circledR}\right)$ and apixaban (Eliquis $\left.{ }^{\circledR}\right)$ that inhibit FXa (13). However, within 11-15 days after knee replacement surgery, net adverse outcomes of bleeding remain as high as $18.9 \%$ for enoxaparin and $9.6 \%$ for rivaroxaban $(12,13,18)$. Moreover, all of these drugs induce hypocoagulability with major bleeding event rates as high as $10.8 \%(13,18)$.

APT102 is a homolog of human apyrase (CD39), the physiologic antiplatelet enzyme on the endothelium that acts to maintain blood fluidity and flow. APT102 has been optimized to inhibit platelet activation and aggregation, and to limit vascular inflammation by scavenging excess extracellular ADP and ATP (19). APT102 does not interfere with platelet function per se; thereby maintaining vascular integrity with no increased bleeding (19-23). The metabolism of ATP and ADP increases AMP, which is further metabolized to vasodilatory and cardioprotective adenosine by endothelial CD73 (19). These features have translated into the capability of APT102 to attenuate thrombosis and ischemia-reperfusion injury in experimental AMI without increased bleeding (19-23). Strikingly, APT102 also extended the therapeutic window for rt-PA-mediated reperfusion following experimental stroke while attenuating hemorrhagic transformation (20). 
Annexin $\mathrm{V}$ is a physiologic anticoagulant protein in the placenta that prevents thrombosis during delivery of the fetus (24). The protein binds to anionic phospholipids, specifically phosphatidylserine (PS) (25). PS moves to the cell surface upon activation of platelets or damage to endothelial cells where it attracts leukocytes and also tethers assembly of prothrombinase and tenase complexes. The competitive binding of annexin V to PS blocks assembly or displaces the procoagulant complexes and thereby attenuates generation of thrombin, the most powerful agonist for platelet activation and catalyst for fibrin formation. Annexin $\mathrm{V}$ binding requires a threshold of 2.5-8\% PS exposure; thereby allowing generation of minute quantities of thrombin needed for normal homeostasis (26). Thus, annexin $\mathrm{V}$ inhibits up to $95 \%$ of platelet-associated prothrombinase activity and up to $95 \%$ of thrombin generation. Indeed, annexin $\mathrm{V}$ was shown to be an effective inhibitor of both venous and arterial thrombosis in vivo without increasing bleeding (27-29). Moreover, annexin $\mathrm{V}$ preferentially binds to thrombi or injured vessels, as compared to non-injured vessels, and thereby targets antithrombotic activity to the vascular injury site $(27,29)$. Annexin $\mathrm{V}$ also provides a potent anti-inflammatory effect by blocking the PS binding site for leukocytes on activated endothelial cell membranes (30). Despite these potential benefits, the clinical utility of annexin $\mathrm{V}$ as a drug has been limited by its small size $(37 \mathrm{kD})$ resulting in rapid renal clearance with a distribution half-life of $5 \mathrm{~min}$ and an elimination half-life of $20 \mathrm{~min}$ (27).

We report here the design and characterization of APT402, an optimized fusion protein of APT102 and annexin V, and compare the pharmacologic effects of APT402 to APT102 and to current FDA-approved antithrombotic therapies during induction of arterial and venous thrombosis in animals. 


\section{Design, optimization, and production of APT102-annexin V fusion proteins.}

We hypothesized that the fusion of APT102 with annexin V would modulate both the platelet and coagulation axes of thrombosis, leading to synergistic antithrombotic efficacy in arterial and venous thrombosis (Fig. 1). In addition, the fusion protein would target sites of platelet activation and/or endothelial cell injury, minimizing systemic bleeding risk. It was also predicted that the fusion protein would prolong the pharmacologic half-life of annexin-V and improve the clinical utility of this physiologic anticoagulant.

The gene encoding human annexin V was fused to the C-terminus of APT102 with linkers of various lengths to optimize expression and function. HEK 293T cells were stably transfected with the linearized expression plasmids and the proteins were purified to homogeneity. The first version of the fusion protein designed with a flexible linker of 20 AA was $50 \%$ degraded in the linker region by protease activity present in the culture medium (fig. S1). Further study showed that low $\mathrm{pH}($ e.g. 5.0) accelerated degradation in the linker sequence compared to $\mathrm{pH} 7.4$. Version 2 was designed with substitution of threonine for glycine at the cleavage site of $\mathrm{P}_{1}$, but was still susceptible to protease degradation when the $\mathrm{pH}$ of the clarified supernatant was reduced to 5 with sodium citrate. However, when this mutation was combined with replacement of serine by alanine or glutamine at the cleavage site $\mathrm{P}_{1}$ (as shown in V3 and V4), the degradation was not visible (fig. S2). Expression levels of V3 were compared with flexible linkers of 5, 10, 15, and 20 amino acid residues or a rigid linker of 9 amino acid residues. The 20AA flexible linker resulted in the highest expression (fig. S3) and no degraded products were detected. The apyrase-annexin V fusion with the 20 AA and protease-resistant linker (V3) was designated as APT402 and chosen for further validation. 
The APT402 gene was subcloned into the GPEx vector and transfected into Chinese Hamster Ovary (CHO-S) cells (31). A purification process was successfully developed, leading to $98 \%$ purity. The host cell protein was $<25 \mathrm{ng} / \mathrm{mg}$ (fig. S4) and the endotoxin in the formulated bulk was $<0.3 \mathrm{EU} / \mathrm{mg}$, which was suitable for the subsequent studies in rabbits.

APT402 exhibits ex vivo antiplatelet efficacy comparable to APT102 while providing synergistic inhibition of activated platelet-associated thrombin generation compared to APT102 or annexin V.

APT402 was designed to maintain the enzymatic and biological activity of both APT102 and the annexin V moieties. Using a malachite green assay (19), we found that the fusion protein maintains typical Michaelis-Menten enzymatic kinetics. The kinetics of APT402 for ADP and ATP were comparable to those of the parent APT102 enzyme. For APT402 and APT102, the $k_{\mathrm{cat}} / K_{\mathrm{m}}$ for ADP was 5.87 and $5.97 \mathrm{uM}^{-1} \mathrm{sec}^{-1}$, respectively, and the $k_{\mathrm{cat}} / K_{\mathrm{m}}$ for ATP was 12.07 and $14.76 \mathrm{uM}^{-1} \mathrm{sec}^{-1}$, respectively (fig. S5, table S1). Similarly, APT402 and APT102 inhibited ADPinduced human platelet activation and aggregation in heparinized platelet-rich plasma with comparable potency, yielding EC50's of 1.92 and $1.74 \mathrm{nM}$, respectively (fig. S6 and table S2). The inhibitory activity on lipopolysaccharide (LPS)-induced factor X activation was assayed using peripheral blood mononuclear cells (PBMC) purified from normal human donors and anesthetized rabbits. There was a similar dose-dependent reduction in factor $\mathrm{X}$ activation by 30 $50 \%$ for both APT402 and human annexin $\mathrm{V}$ in rabbit and in human peripheral blood mononuclear cells (PBMCs, fig. S7). As anticipated, APT102 had no effect on LPS-induced procoagulant activity.

The effect on thrombin generation was determined in human platelet-poor and plateletrich plasmas (PPP, PRP) (32). APT102 had a negligible effect on thrombin generation in PPP 
(fig. S8A). In contrast, both annexin V and APT402 dose-dependently delayed the time to peak and decreased peak thrombin concentration with comparable potency at equimolar concentrations in PPP (figs. S8, B to D). APT102 slightly delayed time to peak and modestly decreased the peak thrombin concentration in $20 \mu \mathrm{M}$ ADP-activated PRP (Fig. 2A), while annexin V and APT402 dose-dependently delayed time to peak thrombin concentration and decreased the peak thrombin concentration (Fig. 2B and 2C). When the reagents were added in equimolar concentrations, APT102 plus annexin V prolonged time to peak thrombin concentration by 6-fold and inhibited the peak thrombin concentration by $60 \%$ compared to no effect and $23 \%$ for APT102 and 2.7fold and 25\% for annexin V, respectively (Fig. 2D). APT402 accurately mimicked the thrombin generation inhibition of APT102 in combination with annexin V.

\section{Pharmacokinetic and pharmacodynamic profiles of APT402 in vivo.}

APT402 was injected IV as a single bolus $(0.4 \mathrm{mg} / \mathrm{kg})$ in anesthetized rabbits. Pharmacokinetic modeling showed best fit to a biphasic exponential curve for ADPase activity (fig. S9). The maximal activity was detected in the plasma $30 \mathrm{~min}$ after administration. The distribution phase and elimination half-life (t/1/2) of APT402 were $30 \mathrm{~min}$ and $6 \mathrm{~h}$, respectively, which were significantly extended by 6 - and 18 -fold compared to the distribution half-life of 5 min and elimination half-life of $20 \mathrm{~min}$ for annexin V (27). Preliminary studies indicated that administration of APT402 displayed a fast onset of action, inhibiting 95\% of $20 \mu \mathrm{M}$ ADP-induced ex vivo platelet aggregation by $10 \mathrm{~min}$ and returning to baseline $60 \mathrm{~min}$ after single bolus IV dosing. These data suggested that to maximize the therapeutic potential of APT402, it should be administered as a bolus followed by continuous IV infusion to ensure consistent attenuation of thrombosis. 
To investigate the pharmacokinetic and pharmacodynamics of APT402, a single IV bolus ( 0.2 $\mathrm{mg} / \mathrm{kg}$ ) followed by IV infusion at 12 or $24 \mu \mathrm{g} / \mathrm{kg} / \mathrm{min}$ for $120 \mathrm{~min}$ was administered to anesthetized rabbits. ELISA data showed that APT402 was detectable in plasma by $15 \mathrm{~min}$ and reached a peak and plateau level 30 min after administration. The steady-state concentration for $24 \mu \mathrm{g} / \mathrm{kg} / \mathrm{min}$ ranged between $1.6-1.7 \mathrm{mg} / \mathrm{L}$, and was approximately double the range of $0.6-0.7$ $\mathrm{mg} / \mathrm{L}$ observed during the $12 \mu \mathrm{g} / \mathrm{kg} / \mathrm{min}$ dose. Protein concentrations were negligible at $180 \mathrm{~min}$ (60 min after discontinuation of the infusion, Fig. 3A). The ex vivo ADPase activity, inhibition of ADP-induced platelet aggregation, and inhibition of thrombin generation were consistent with the plasma concentrations of APT402 during infusion, then returned to baseline levels within 60 min after discontinuation of the infusion (Fig. 3, B to D). When the steady-state level was reached with administration of APT402 at $24 \mu \mathrm{g} / \mathrm{kg} / \mathrm{min}$, the time to peak thrombin concentration in platelet-poor plasma was prolonged by 2 -fold and the peak thrombin concentration was decreased by $77-82 \%$ compared to the baseline (Fig. 3D). These data show that the optimal inhibitory level of APT402 was achieved within 30 min of the start of infusion and could be achieved by pretreatment to ensure attenuation of both local and systemic thrombosis as blood flow in the affected artery is restored.

\section{APT402 is preferentially targeted to sites of arterial injury and thrombosis.}

Electrolytic injury-induced thrombosis was initiated in a carotid artery of anesthetized rabbits $30 \mathrm{~min}$ after a bolus injection $(0.2 \mathrm{mg} / \mathrm{kg})$ and the start of an infusion of APT402 at 12 or $24 \mu \mathrm{g} / \mathrm{kg} / \mathrm{min}$ for $120 \mathrm{~min}$ (33), with some receiving APT402 containing tracer quantities of near infrared (NIR)-labeled APT402 as described (34). Other rabbits given a bolus of APT102 (1.0 $\mathrm{mg} / \mathrm{kg}$ ) received a tracer quantity of NIR-labeled APT102 as a control (fig. S10). Fluorescence intensity at the injury site was not different from the baseline in the NIR-APT102-treated animals 
(Fig. 4A). In contrast, fluorescence was approximately 6-7-fold higher than baseline in the NIRAPT402-treated animals (Fig. 4B). Fluorescence signal did not increase in the non-injured control artery. Similar to previous studies examining administration of annexin $\mathrm{V}$ in rabbits $(27,28)$, these data confirm that APT402 was preferentially targeted to the site of arterial injury and thrombosis (Fig. 4C).

\section{APT402 maintains patency and more effectively attenuates arterial thrombosis in rabbits without increasing bleeding risk compared to standard-of-care agents}

The rabbit electrolytic injury model of arterial thrombosis was used to define the dose-response of APT402 and to compare the antithrombotic efficacy and bleeding risk of APT402 to APT102 and to current FDA-approved antiplatelet (clopidogrel, ticagrelor) and anticoagulant (enoxaparin, bivalirudin) agents administerd alone or in combination (ticagrelor + bivalirudin) (33). In addition, hydroxypropyl methylcellulose (HPMC), the chemical agent needed for efficient ticagrelor absorption from the gut, and saline vehicle for other agents were included as separate control groups. Since strong antithrombotic effects were observed in the preliminary studies of APT402 with $0.2 \mathrm{mg} / \mathrm{kg}$ single IV bolus followed by $12 \mu \mathrm{g} / \mathrm{kg} / \mathrm{min}$, we examined the antithrombotic effect of this regimen as well as higher $(24 \mu \mathrm{g} / \mathrm{kg} / \mathrm{min})$ and lower $(4 \mu \mathrm{g} / \mathrm{kg} / \mathrm{min})$ infusion rates with the same initial bolus dose $(0.2 \mathrm{mg} / \mathrm{kg})$. Rabbits were randomized into eleven groups with the treatments initiated $30 \mathrm{~min}$ before electrolytic injury and continued for $120 \mathrm{~min}$ after the initiation of the electrolytic injury ( $\mathrm{n}=10$ and 6/group for the placebo control and treatment groups, respectively).

Electrolytic injury resulted in complete occlusion within $120 \mathrm{~min}$ in $60 \%$ of the rabbits treated with placebo (table S3), with a mean thrombosis weight of $7.8 \pm 2.2 \mathrm{mg}$ (table S4). HPMC had no significant effect on occlusion, thrombus weight, or bleeding time compared to the placebo 
control (Figure 5; table S3, S4, S5). Treatment with APT402 at 12 or $24 \mu \mathrm{g} / \mathrm{kg} / \mathrm{min}$ or ticagrelor, either alone or in combination with bivalirudin, prevented occlusion in all tested rabbits (Fig. 5A, table S3). Enoxaparin, bivalirudin, and APT402 at $4 \mu \mathrm{g} / \mathrm{kg} / \mathrm{min}$ partially prevented occlusion (67, 86 , and $83 \%$, respectively). Compared to the control group, thrombosus weight was significantly reduced by $83 \%$ and $95 \%$, respectively, with APT 402 at 12 or $24 \mu \mathrm{g} / \mathrm{kg} / \mathrm{min}$ and by $80 \%$ with ticagrelor plus bivalirudin (Fig. 5B, table S4). Treatment with ticagrelor, APT102, and APT402 at $4 \mu \mathrm{g} / \mathrm{kg} / \mathrm{min}$ trended to reduce thrombus weight by 68,66 and $62 \%$, respectively ( $\mathrm{p}=0.05,0.05$, and 0.07). Strikingly, treatment with APT402 at $24 \mu \mathrm{g} / \mathrm{kg} / \mathrm{min}$ almost completely prevented measurable thrombus formation (thrombus weight of $0.4 \pm 0.1 \mathrm{mg}$ ) and trended to be more effective in attenuating thrombus weight than the combination of ticagrelor and bivalirudin $(\mathrm{p}=0.06)$.

Consistent with our previous study (19), APT102 had no significant effect on bleeding time (BT, Fig. 5C, fig. S11, and table S5), prothrombin time (PT, fig. S12 and table S6), or activated partial thromboplastin time (aPTT, fig. S13 and table S7). At doses that completely prevented thrombotic occlusion, APT402 did not significantly prolong BT or PT and only marginally increased aPTT after 120 min of drug administration (Fig 5; fig S11, S12, S13). In contrast, treatment with clopidogrel, ticagrelor, enoxaparin, bivalirudin, or ticagrelor plus bivalirudin, all significantly prolonged BT (Fig. 5C, fig. S11, and table S5). Treatment with bivalirudin or ticagrelor plus bivalirudin significantly prolonged PT and aPTT and enoxaparin significantly increased aPTT (Fig. 5D, figs. S12 and S13, tables S6 and S7). None of the treatments significantly affected blood pressure or heart rate (figs. S14 and S15, tables S8 and S9).

\section{APT402 attenuates venous thrombosis in mice without increasing bleeding or inducing hypocoagulability.}


Healthy mice received two days of treatment with enoxaparin at $6 \mathrm{mg} / \mathrm{kg} \mathrm{SC}$, a dose proven to demonstrate antithrombotic efficacy in mouse models of thrombosis $(33,34)$, or with APT402 at $0.2 \mathrm{mg} / \mathrm{kg} \mathrm{IP}$, followed by an SC infusion at $1.5 \mu \mathrm{g} / \mathrm{kg} / \mathrm{min}$. Enoxaparin significantly prolonged BT and aPTT (fig. S16, tables S10 and S11). In contrast, APT402 had no effect on BT or aPTT. Neither enoxaparin nor APT402 treatment affected whole blood cell counts compared to the placebo controls (table S12).

An electrolytic injury model of venous thrombosis was used to assess antithrombotic efficacy of APT402 in mice $(35,36)$. Thrombus weight, BT, aPTT, and Thrombin Clotting Time (TCT) were measured $48 \mathrm{~h}$ after thrombus induction in the inferior vena cava. Venous thrombosis was consistently generated in all placebo-treated mice, with the mean thrombus weight of $26.0 \pm 1.3 \mathrm{mg}$ (Fig. 6A and table S13). Treatment with enoxaparin significantly reduced thrombus weight by $63 \%$ compared to controls, but was associated with a significant prolongation of BT by 5 -fold, aPTT by 2.3-fold, and thrombin clotting time (TCT) by 2-fold (Fig. 6, B-D, tables S14-16). In contrast, APT 402 reduced thrombus weight by $44 \%$ and $65 \%$ at the doses of 0.5 and $1.5 \mu \mathrm{g} / \mathrm{kg} / \mathrm{min}$, respectively, without significantly affecting BT or TCT and only modestly increasing aPTT at the higher dose, compared to controls (Fig. 6, B-D, tables S14-16). 


\section{Discussion.}

Coronary artery disease is the leading cause of death worldwide with 3.8 million men and 3.4 million women dying of the disease each year (37). Furthermore, the number of chronically ill cardiovascular patients is increasing due to aging of the population. Every year, 15 million people suffer AIS, which remains the leading cause of long-term disability and the second leading cause of death worldwide. Likewise, venous thromboembolism (VTE) is the third most common cardiovascular disease in the world, with an estimated 150,000 deaths and 900,000 hospitalizations per year in the US and Europe (38). Incomplete reperfusion caused by thrombotic reocclusion at the site of the original vessel occlusion or by distal embolization represent the major causes of morbidity and mortality in these diseases. Recently, thrombotic and bleeding diatheses have also been identified in a significant number of hospitalized COVID-2019 patients who exhibit platelet hyperactivation, coagulopathy, and bleeding complications (39). Although there have been improvements in antithrombotic therapy in the past few years, bleeding complications remain an inevitable side effect of current antiplatelet and anticoagulant agents due to their intrinsic mechanisms of action, highlighting the importance of developing safer and more effective therapeutic alternatives $(40)$.

In many clinical settings, antithrombotic therapy consists of a combination of antiplatelet and anticoagulant agents (41). In these patients, the individual agents carry separate bleeding risks that are accentuated by the combination such that the physician must balance the thrombotic and bleeding risks of each patient individually. Even more troubling is the challenge of medically managing these patients to reduce periprocedural risks of thrombosis and bleeding when they require urgent or elective surgery (42). The optimal agent for these indications would be a 
combined antiplatelet and anticoagulant inhibitor that does not increase bleeding risk so it can be given safely and provide the required antithrombotic efficacy in a variety of clinical situations.

Harnessing the potential of naturally occuring antithrombotic proteins, APT402 combines the antiplatelet properties of an optimized human apyrase, APT102, with the anticoagulant activity of annexin $\mathrm{V}$ to produce a potent antithrombotic agent with minimal bleeding risk. In addition, the therapeutic index may be further increased by the thrombus-targeting property of the fusion protein. In this study, APT402 inhibited thrombosis in a rabbit model of arterial thrombosis and in a murine model of venous thrombosis at doses that did not increase bleeding time or markers of systemic hypocoagulability. As expected, inhibition of thrombosis with the FDA-approved comparators used in these experiments was accompanied by increased bleeding time and markers of systemic hypocoagulability. These data indicate that APT402 represents a new paradigm for treatment or prevention of thrombotic diseases, potentially breaking the confounding link between antithrombotic potency and dose-limiting bleeding side effects seen with conventional therapy. The safe and effective administration of APT402 will not require diagnostic testing of bleeding risk or assessment of the patient's state of coagulation, which will simplify treatment for patients with acute thrombotic occlusion or risk. Moreover, APT402 may be uniquely positioned as a lifesaving therapy for patients undergoing surgery or stroke treatment with rt-PA, for which no antithrombotic drugs have been indicated due to associated bleeding risks. 


\section{REFERENCES AND NOTES}

1. N. Curzen, et al. What is the optimum adjunctive reperfusion strategy for primary percutaneous coronary intervention? Lancet. 382, 633-643 (2013).

2. J. P. Broderick, Stroke therapy in the year 2025: burden, breakthroughs, and barriers to progress. Stroke. 35, 205-211 (2004).

3. D. M. Yellon, D. J. Hausenloy, Myocardial reperfusion injury. N. Engl. J. Med. 357, 11211135 (2007).

4. I.D. Pena ID et al. Strategies to extend thrombolytic time window for ischemic stroke treatment: An unmet clinical need. J Stroke. 19, 50-60 (2017).

5. W. E. Boden, K. Eagle, C.B. Granger- Reperfusion strategies in acute ST-segment elevation myocardial infarction. J. Am. Coll. Cardiol. 50, 917-927 (2007).

6. P. H. Nielsen et al. Primary angioplasty versus fibrinolysis in acute myocardial infarction. Circulation. 121, 1484-1491 (2010).

7. N. Mackman, et al. Dual anticoagulant and antiplatelet therapy for coronary artery disease and peripheral artery disease patients. Arterioscler. Thromb. Vasc. Biol. 38, 726-732 (2018).

8. T. Gremmel et al. Novel aspects of antiplatelet therapy in vascular disease. Res. Pract. Thromb. Haemost. 2, 439-449 (2018).

9. S. D. Wiviott et al. Prasugrel versus clopidogrel in patients with acute coronary syndromes $N$. Engl. J. Med. 357, 2001-2015 (2007).

10. L. Wallentin et al. Ticagrelor versus clopidogrel in patients with acute coronary syndromes. $N$. Engl. J. Med. 361, 1045-1057 (2009).

11. G. Parodi et al. Comparison of prasugrel and ticagrelor loading doses in ST-segment elevation myocardial infarction patients. J. Am. Coll. Cardiol. 61, 1601-1606 (2013). 
12. J. L. Mega et al. Rivaroxaban in patients with a recent acute coronary syndrome. $N$. Engl. J. Med. 366, 9-19 (2011).

13. M. Ufer. Comparative efficacy and safety of the novel oral anticoagulants dabigatran, rivaroxaban and apixaban in preclinical and clinical development. Thromb. Haemost. 103, 572$585(2010)$

14. R. Mehran et al. Associations of major bleeding and myocardial infarction with the incidence and timing of mortality in patients presenting with non-ST-elevation acute coronary syndromes: a risk model from the ACUITY trial. Eur Heart J 30, 1457-1466 (2009).

15. K. R. Lees et al. Time to treatment with intravenous alteplase and outcome in stroke: an updated pooled analysis of ECASS, ATLANTIS, NINDS, and EPITHET trials. Lancet. 375, 1695-1668, (2010).

16. K. R. Machlus et al. Update on venous thromboembolism. Risk factor, mechanisms, and treatments. A.T.V.B. 31, 476-478 (2011).

17. P. A. Kyrle, S. Eichinger, Deep vein thrombosis. Lancet. 365, 1163-1174 (2005).

18. J. Saarinen et al. The occurrence of the post-thrombotic changes after an acute deep venous thrombosis. J. Cardiovasc. Surg. 41, 441-446 (2000).

19. D. Moeckel et al. Optimizing human apyrase to treat arterial thrombosis and limit reperfusion injury without increasing bleeding risk. Sci. Transl. Med. 6, 248ra105 (2014).

20. Z. Tan et al. Combination treatment of r-tPA and an optimized human apyrase reduces mortality rate and hemorrhagic transformation $6 \mathrm{~h}$ after ischemic stroke in aged female rats. Eur. J. Pharmacol. 738, 369-373 (2014).

21. M. Ibrahim M et al. Human recombinant apyrase therapy protects against canine pulmonary ischemia-reperfusion injury. J. Heart. Lung. Transplant. 34, 247-253 (2015). 
22. Y. Ji et al. Recombinant soluble apyrase APT102 inhibits thrombosis and intimal hyperplasia in vein grafts without adversely affecting hemostasis or re-endothelialization. J. Thromb. Haemost. 15, 814-825 (2017).

23. Z. Q. $\mathrm{Xu}$ et al. Human recombinant apyrase therapy protects against myocardial ischemia/reperfusion injury and preserves left ventricular systolic function in rats, as evaluated by 7T cardiovascular magnetic resonance imaging. Korean. J. Radiol. 21, 6470659 (2020).

24. H. Ueki et al. Loss of maternal annexin A5 increases the likelihood of placental platelet thrombosis and foetal loss. Sci. Rep. 2, 827 (2012).

25. V. Gerke, S. Moss S. Annexins: from structure to function. Physiol. Rev. 82, 331-371 (2001).

26. J. Shi et al. Lactadherin blocks thrombosis and hemostasis in vivo: correlation with platelet phosphatidylserine exposure. J. Thromb. Haemost. 6, 1167-1174 (2008).

27. P. Thiagarajan, C. R. Benedict.- Inhibition of arterial thrombosis by recombinant annexin V in a rabbit carotid artery injury model. Circulation. 96, 2339-2347 (1997).

28. W.L. Van Heerde et al. Annexin V inhibits the procoagulant activity of matrices of TNFstimulated endothelium under flow conditions. Arterioscler. Thromb. 14, 824-830 (1994).

29. J. Van Ryn McKenna et al.The effect of heparin and annexin V on fibrin accretion after injury in the jugular vein of rabbits. Thromb. Haemost. 69, 227-230 (1993).

30. J. Qu et al. Phosphatidylserine-mediated adhesion of T-cells to endothelial cells. Biochem. J. 317, 343-346 (1996).

31. G. T. Bleck. An alternative method for the rapid generation of stable high-expressing mammalian cell lines. BioProcess J. 5, 1-7 (2006).

32. H. C. Hemker, R. Al Dieri, S. Beguin. Thrombin generation assays: accruing clinical relevance. Curr. Opin. Hematol. 11, 170-175 (2004). 
33. P. K. Baum, D. Martin, D. Abendschein, A preparation to study simultaneous arterial and venous thrombus formation in rabbits. J. Invest. Surg. 14,153-160 (2001).

34. D. Maji, et.al. Noninvasive imaging of focal atherosclerotic lesions using fluorescence molecular tomography. J. Biomedical Optics 19, 11501-3 (2014).

35. J. A. Diaz et al. Electrolytic Inferior Vena Cava Model (EIM) of Venous Thrombosis. J. Vis. Exp. 53, e2737 (2011).

36. J. A. Diaz et al. Choosing a Mouse Model of Venous Thrombosis A Consensus Assessment of Utility and Application. Arterioscler. Thromb. Vasc. Biol. 39, 311-318 (2019).

37. J. Mackay, G. Mensah, Eds., The atlas of heart disease and stroke (World Health Organization, Geneva, 2004).

38. M.G. Beckman, et al. Venous Thromboembolism. A Public Health Concern. Thromb. Disorder. 38, S495-S501 (2010).

39. Al-Samkari H, et al. COVID-19 and coagulation: bleeding and thrombotic manifestations of SARS-CoV-2 infection. Blood. 136, 489-500 (2020).

40. J. I. Weitz, N. C. Chan, Advances in antithrombotic therapy. Arterioscler. Thromb. Vasc. Biol. 39, 7-12 (2019).

41. C.N. Floyd, A. Ferro. Indications for anticoagulant and antiplatelet combined therapy. Brit Med J. 359, j3782 (2017).

42. D. Keeling, R.C. Tait, H. Watson. Peri-operative management of anticoagulation and antiplatelet therapy British J of Haematol, 175, 602-613 (2016).

43. A. A. Baykov, O. A. Evtushenko, S. M. Avaeva. A malachite green procedure for orthophosphate determination and its use in alkaline phosphatase-based enzyme immunoassay. Anal Biochem 171, 266-270 (1988). 
44. P. C. Wong et al. Clopidogrel versus prasugrel in rabbits. Effects on thrombosis, haemostasis, platelet function and response variability. Thromb Haemost. 101, 108-115 (2009).

45. D. R. Abendschein et al. Effects of ZK-807834, a novel inhibitor of factor Xa, on arterial and venous thrombosis in rabbits. J Cardiovasc Pharmacol. 35, 796-805 (2000).

46. J. T. Liu et al. Thrombin inhibitors and anti-coagulants on thrombin-induced embolization in rabbit cranial vasculature. Eur J Pharmacol. 264, 183-190 (1994). 
Acknowledgments: We thank Pamela Baum, Susannah Grathwohl, and Megan Verbera for veterinary and technical assistance with the rabbit studies; Annie Nguyen, Nicholas Karlow, Maya Mahendran, Ifrah Amed, Havisha Pedamallu, and Sharanya Thondapu for blood sample processing, analysis of PT and aPTT, and data and graphical analysis; Samuel Achilefu and Joseph Culver for development of the NIR technology, probes, and instrumentation to make non-invasive measurements of NIR-APT binding to thrombus; Haiying Zhou and Dolonchampa Maji for preparation of the NIR-tagged APT compounds; and Gail Sudlow for sectioning the arterial thrombi and taking pictures of NIR-APT402 binding to carotid thrombus.

Funding: This work was supported by NIH grant HL135993 (to R.C., D.A.) and APT Therapeutics Inc fund.

Author contributions: D. A. designed and performed the arterial thrombosis and PK/PD experiments, reviewed all collected data, and helped write and edit the manuscript. S. J. helped design and produce the compounds, performed assays of platelet function and thrombin activity during in vivo studies, and helped write the manuscript. J.D. and T. W. designed and performed the venous experiments. K.B. and M.S. performed the NIR imaging experiments and analyzed the data. R. L. helped design the experiments and edited the manuscript. R.C. designed the compounds, designed and coordinated the experiments, secured the funding, and wrote the manuscript draft.

Competing interests: R. C. and S.J. have equity interest in APT Therapeutics Inc, which held patents, patent applications, and commercial rights to APT102 and APT402. The other authors declare that they have no competing interests.

\section{List of Supplementary Materials:}

figs. S1 to S16; tables S1 to S16 


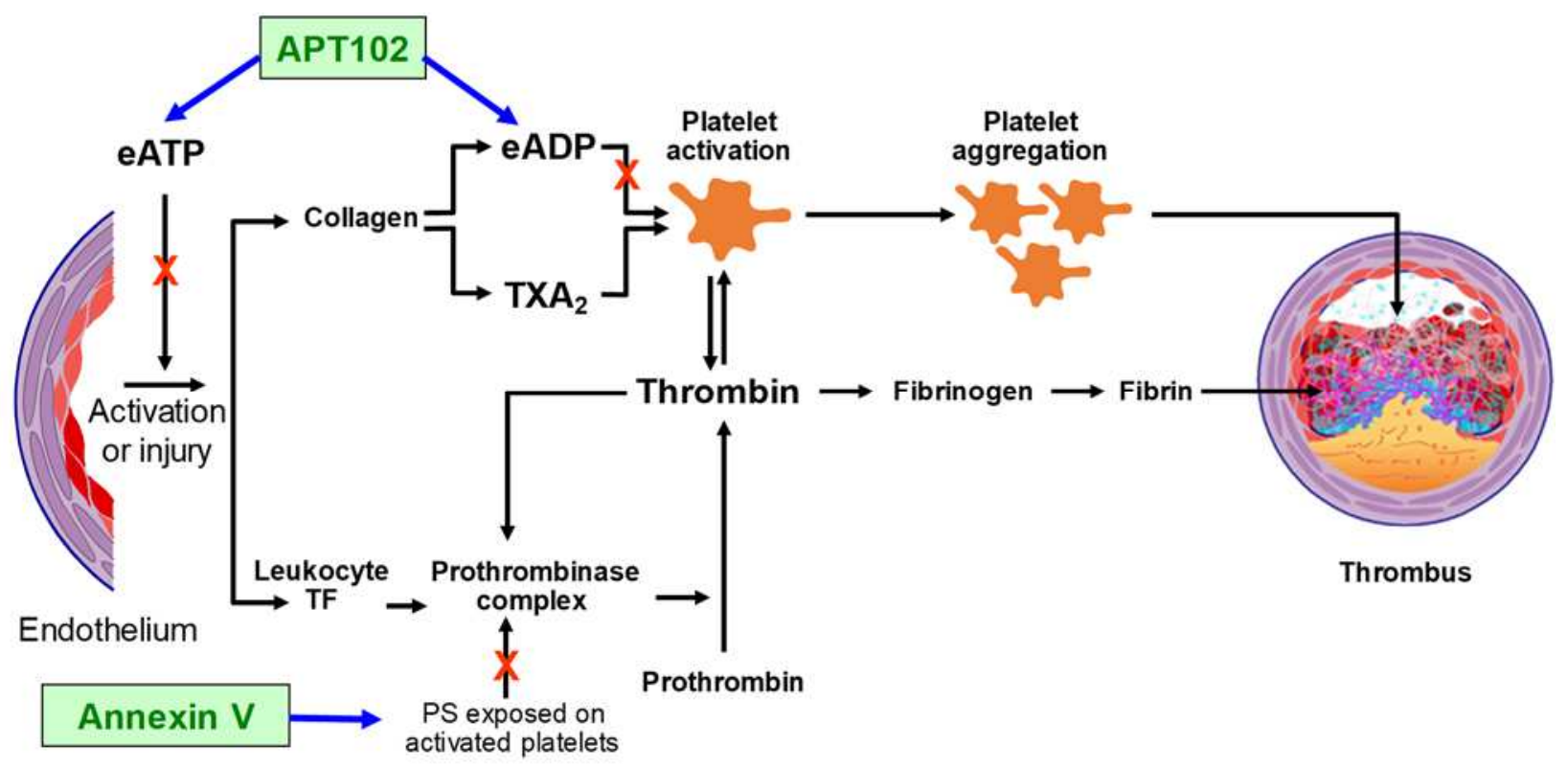

Fig. 1. Potential synergy of APT102 and annexin V for attenuation of arterial thrombosis. Administration of APT102, the optimized human apyrase, scavenges eADP and eATP and attenuates platelet activation and aggregation as well as inflammation. Annexin $\mathrm{V}$ binding to phosphatidylserine (PS) blocks the formation of the prothrombinase complex and thereby attenuates the generation of thrombin, the most powerful agonist for platelet activation and the catalyst for fibrin formation. Fusion with annexin V targets APT102 to the thrombotic site; while fusion with APT102 extends the half-life of the annexin V moiety in the circulation. 

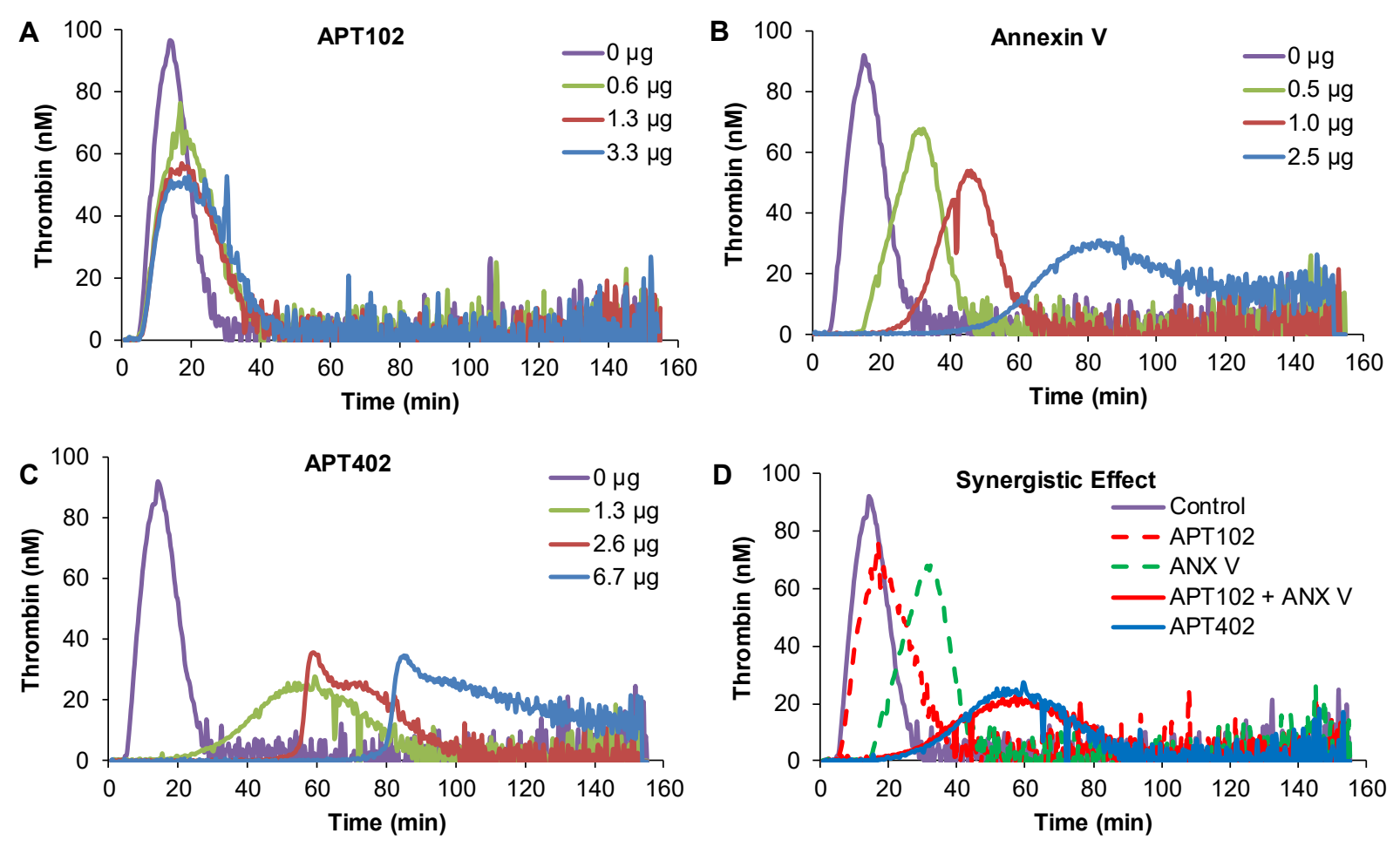

Fig. 2. Effect of APT102 and annexin V (ANX V) on attenuation of thrombin generation in human platelet-rich plasma activated with $20 \mu \mathrm{M}$ ADP. APT102 modestly decreased the peak thrombin concentration (A), while annexin V (B) and APT402 (C) dose-dependently prolonged time to peak thrombin and decreased the peak thrombin concentration. (D) APT102 $(0.6 \mu \mathrm{g})$ plus annexin V (ANX V, $0.5 \mu \mathrm{g}$ ) synergistically inhibited thrombin generation compared to APT102 or annexin V alone. APT402 at equimolar concentration mimicked the thrombin generation inhibition of APT102 plus annexin V. 

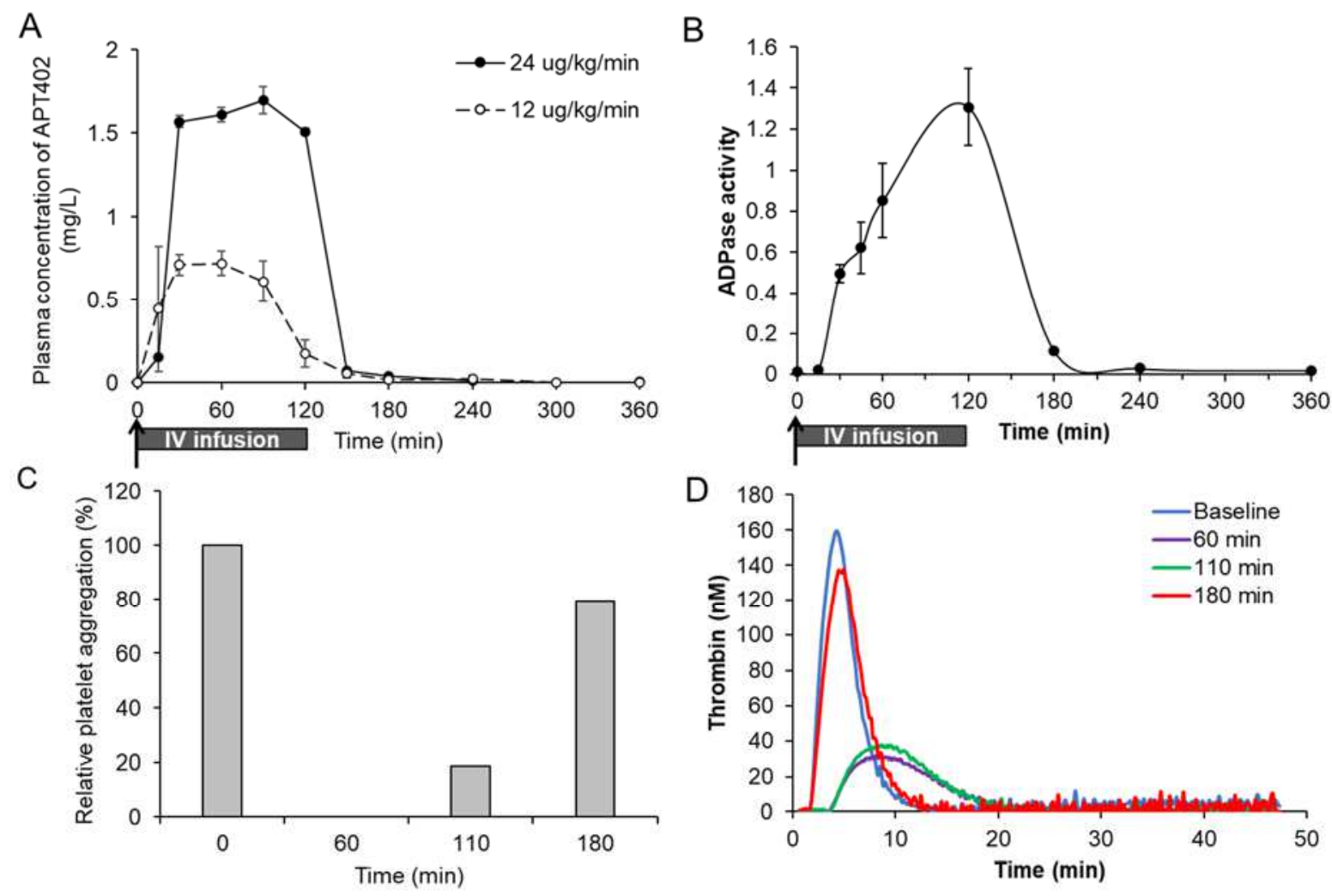

Fig. 3. Pharmacokinetic and pharmacodynamic analysis of APT402. Pharmacokinetics of APT402 with bolus injection at $0.2 \mathrm{mg} / \mathrm{kg}$ followed by continuous IV infusion at 12 or 24 $\mu \mathrm{g} / \mathrm{kg} / \mathrm{min}$ for $120 \mathrm{~min}$ in rabbits $(\mathrm{n}=2-3)$. A. APT402 protein was dose-dependently detectable with immunoassay at $30 \mathrm{~min}$, reached steady-state levels during infusion and returned to undetectable levels $1 \mathrm{~h}$ after discontinuation. B. Enzyme activity of APT402 $(0.2 \mathrm{mg} / \mathrm{kg}$ bolus plus $24 \mu \mathrm{g} / \mathrm{kg} / \mathrm{min}, \mathrm{IV})$. C. APT402 administration ( $0.2 \mathrm{mg} / \mathrm{kg}$ bolus plus $24 \mu \mathrm{g} / \mathrm{kg} / \mathrm{min}, \mathrm{IV})$ inhibited ADP-induced $(50 \mu \mathrm{M})$ ex vivo platelet aggregation in rabbit platelet-rich plasma completely at 60 min and nearly completely at $110 \mathrm{~min}$ and returned to near baseline levels by $180 \mathrm{~min}(60 \mathrm{~min}$ after administration was terminated). D. Ex vivo thrombin generation in platelet- poor plasma was effectively attenuated with APT402 administration $(0.2 \mathrm{mg} / \mathrm{kg}$ bolus plus $24 \mu \mathrm{g} / \mathrm{kg} / \mathrm{min}$, iv. $)$ at 60 and $110 \mathrm{~min}$ and returned to the baseline level at $180 \mathrm{~min}(60 \mathrm{~min}$ after administration was terminated). 


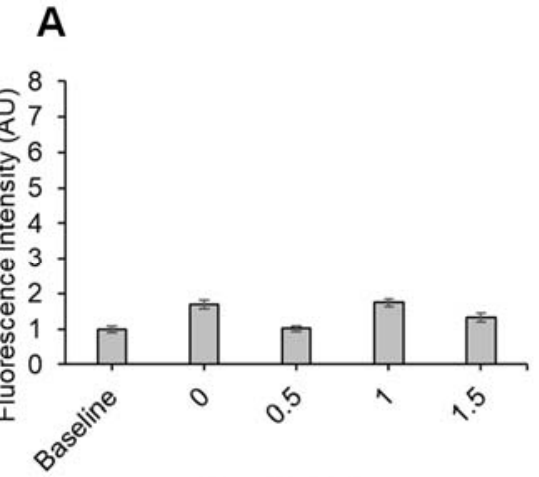

Hour Post Injury

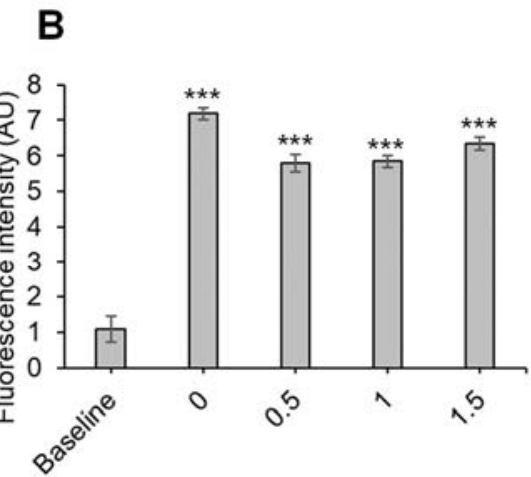

Hours Post Injury
C

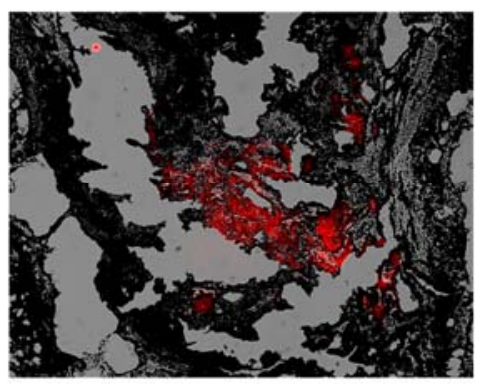

Fig. 4. APT402 bound to the thrombus in injured arteries. A. Fluorescent intensity in the injured artery of a rabbit treated with NIR-labeled APT102 at $0.2 \mathrm{mg} / \mathrm{kg}$. Each bar represents the mean of three readings obtained with a probe array over the neck. There were no significant changes in the fluorescence intensity between the baseline and the other timepoints. B. Fluorescent intensity in the injured artery of rabbits treated with APT402 at $0.2 \mathrm{mg} / \mathrm{kg}$ bolus followed by 12 or $24 \mu \mathrm{g} / \mathrm{kg} / \mathrm{min}$ for $90 \min (\mathrm{n}=4)$. Fluorescence intensity relative to baseline was significantly increased throughout the interval of carotid injury. C. APT402 (red) bound to thrombus formed on an injured carotid artery. Epifluorescence of a $10 \mu \mathrm{m}$ section of thrombus (frozen in OCT) was imaged using a Cy7 filter with excitation at 710/75 and emission at 810/90 using dichroic 750LP film and 20 s exposure. ${ }^{* * *} \mathrm{p}<0.001$. 

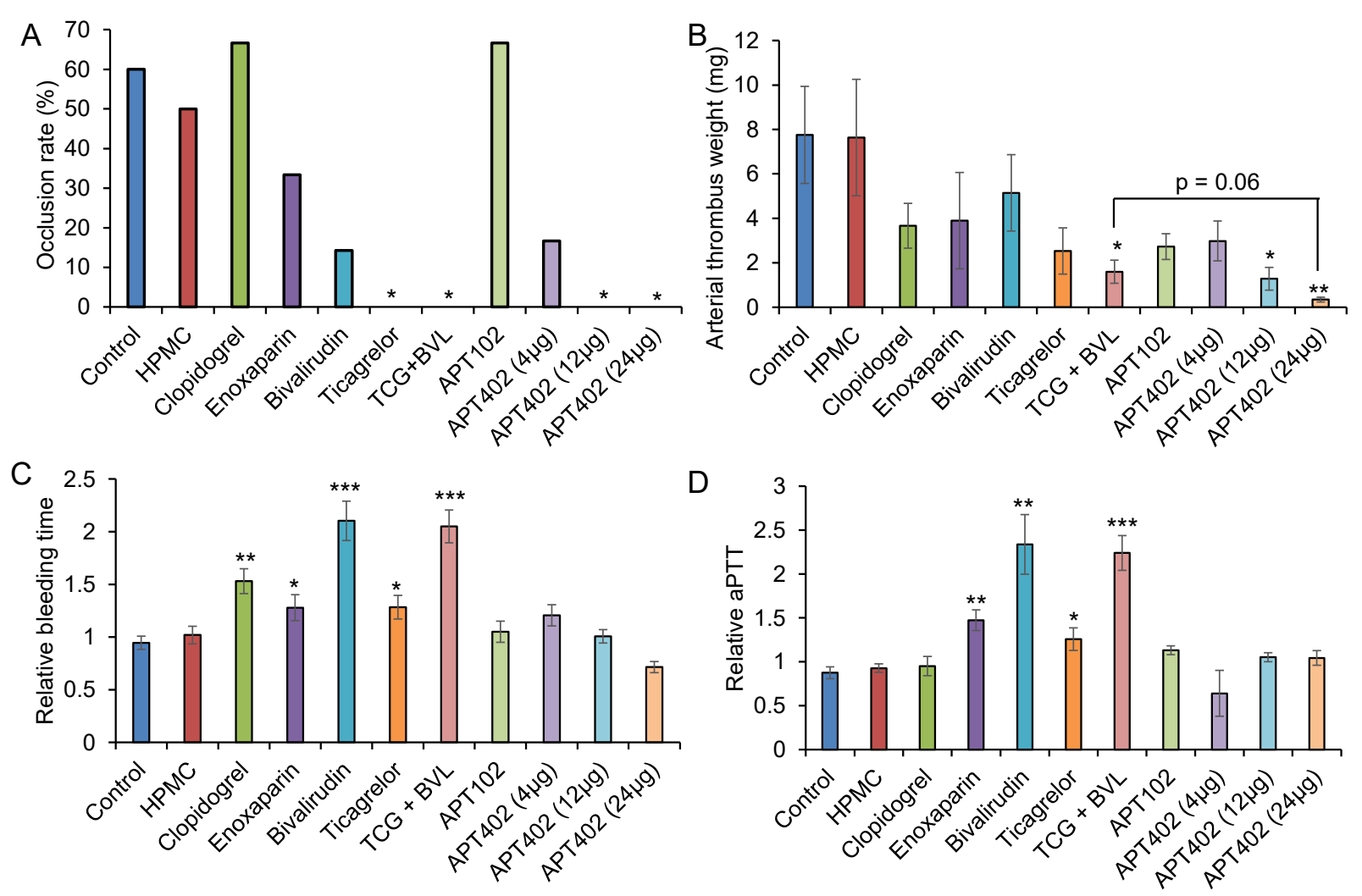

Fig. 5. APT402 attenuated arterial thrombosis in rabbit carotids compared to current antithrombotic drugs without increasing bleeding risk. A. Arterial occlusion was completely prevented with ticagrelor, ticagrelor plus bivalirudin, or APT402 at 12 and $24 \mu \mathrm{g} / \mathrm{kg} / \mathrm{min}$. B. Arterial thrombus weight was significantly reduced with ticagrelor plus bivalirudin and with APT402 at 12 or $24 \mu \mathrm{g} / \mathrm{kg} / \mathrm{min}$. APT402 at $24 \mu \mathrm{g} / \mathrm{kg} / \mathrm{min}$ almost completely prevented measurable thrombus formation (thrombus weight of $0.4 \pm 0.1 \mathrm{mg}$ ) and trended to be more effective in reducing thrombus weight than ticagrelor plus bivalirudin. $\mathrm{C}$ and $\mathrm{D}$. While current drugs increased bleeding time and activated partial thromboplastin time at $60 \mathrm{~min}$ after initiation of treatment, neither APT102 nor APT402 affected these parameters compared with hydroxypropyl methycellulose (HPMC $\mathrm{n}=6)$ and control groups $(\mathrm{n}=10) . \mathrm{n}=6$ for other groups. ${ }^{*} \mathrm{p}<0.05 ;{ }^{* *} \mathrm{p}<0.01$, $* * * \mathrm{p}<0.001$. 

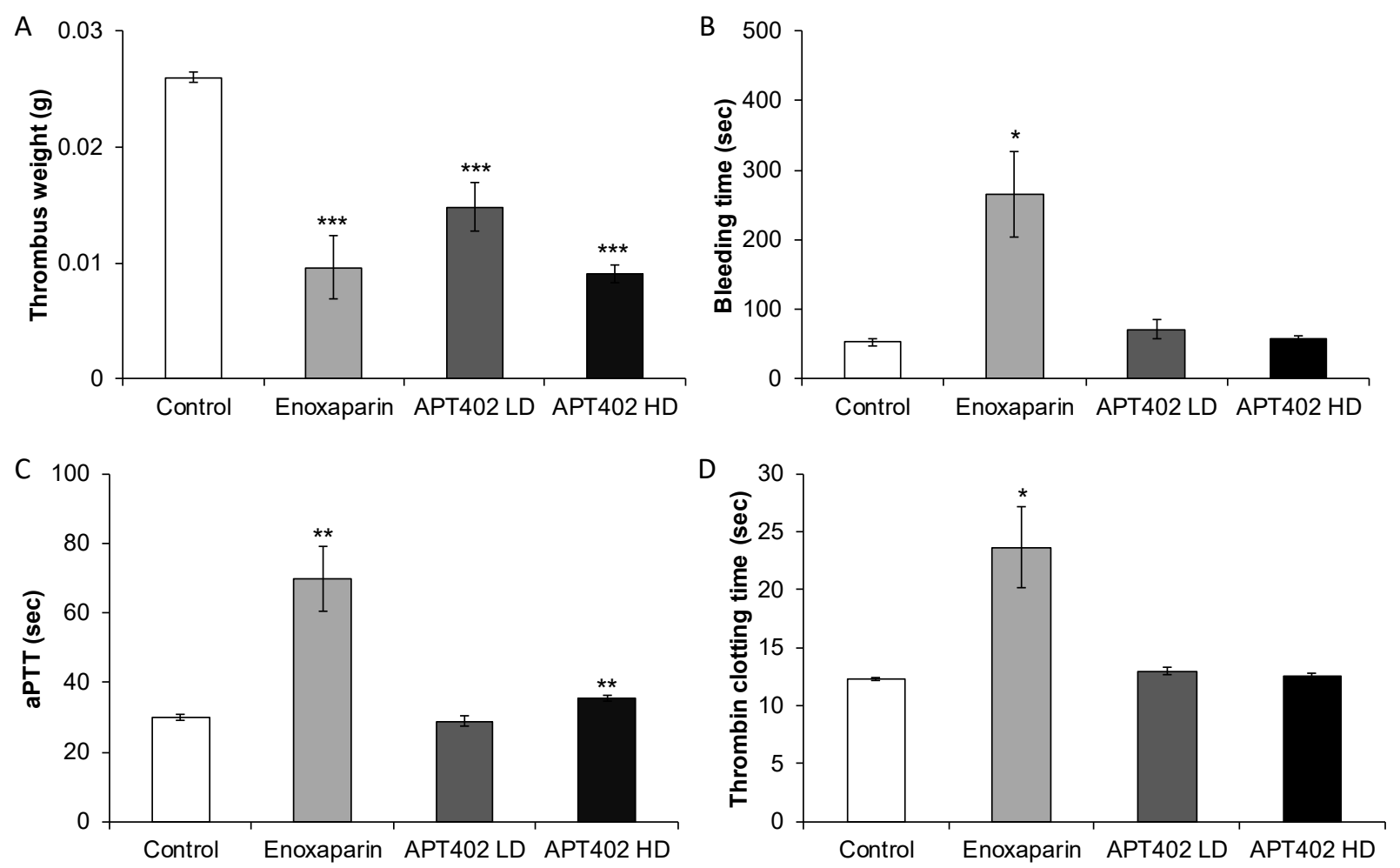

Fig. 6. APT402 attenuated venous thrombosis without increasing bleeding risk in mice. A.

Thrombus weight; B. Bleeding time; C. Activated partial thromboplastin time; D. Thrombin clotting time. Mice were treated at thrombus initiation and continuing for 2 days post-thrombosis with saline, enoxaparin at $6 \mathrm{mg} / \mathrm{kg} / \mathrm{day} \mathrm{SC}$, APT402 at $0.2 \mathrm{mg} / \mathrm{kg}$ IP plus $48 \mathrm{~h} \mathrm{SC}$ infusion at 0.5 $\mu \mathrm{g} / \mathrm{kg} / \mathrm{min}$ (LD) or $1.5 \mu \mathrm{g} / \mathrm{kg} / \mathrm{min}$ (HD). Endpoints were measured at 48h. Enoxaparin (low molecular weight heparin) at effective antithrombotic dose significantly increased bleeding time, activated partial thromboplastin time, and thrombin clotting time. $\mathrm{n}=9-10$ per group. ${ }^{*} \mathrm{p}<0.05$; $* * \mathrm{p}<0.01, * * * \mathrm{p}<0.001$ 


\section{MATERIALS AND METHODS}

\section{Study Design}

Predefined study components: Previous data indicated that six (6) animals were required in each group for the rabbit model of arterial thrombosis in order to detect a $50 \%$ difference in thrombus weight with $80 \%$ power and type I error probability of 0.05 . Ten (10) animals per group resulted in $80 \%$ power to detect $30 \%$ differences in the mouse acute venous thrombosis model.

Rationale and design of study: The overall objective of the study was to determine whether APT402 more effectively attenuated injury-induced arterial thrombosis in rabbits and venous thrombosis in mice with minimal risk of bleeding compared with current antiplatelet agents and anticoagulants. The primary efficacy endpoint was thrombus weight.

Replication: All groups were sufficiently powered to meet the desired objectives. Assays of platelet function, thrombin generation, and blood analytes were done in duplicate or triplicate as indicated.

\section{Sequence analysis and computer graphics}

GenBank and Swiss-Prot databases were searched for amino acid sequence similarities using the BLAST and PSI-BLAST programs. X-ray crystallographic structures were visualized with Swiss PDB Viewer.

\section{Gene cloning}

The DNA sequences of APT102, linker, and human annexin V were synthesized and cloned into expression plasmid pSEQTAG2a (Invitrogen, Waltham, MA), a vector suitable for production of secreted recombinant protein in HEK $293 \mathrm{~T}$ cells. To facilitate cloning, pSEQTAG2a was modified by site-directed mutagenesis (Quick Change, Stratagene, LaJolla, CA) to introduce an Srf I restriction site in frame with the Igk leader sequence. The Sma I fragment of the genes was 
then translationally fused to the Srf I site. The GPEX vector (Catalent, Madison, WI) was used for stable CHO cell expression, as described previously (31).

\section{Site-Directed Mutagenesis}

Point mutations were introduced using a mutagenesis kit (Stratagene) according to the manufacturer's instructions. The entire open reading frames of the mutants generated were verified by DNA sequence analysis.

\section{Protein expression and purification}

Expression plasmids of APT102-annexin V fusion proteins were transfected into 293T cell lines. Transiently transfected cells were selected in the presence of Zeocin (Invitrogen, Waltham, MA). Selected colonies were grown to full confluence and then inoculated into 15-30

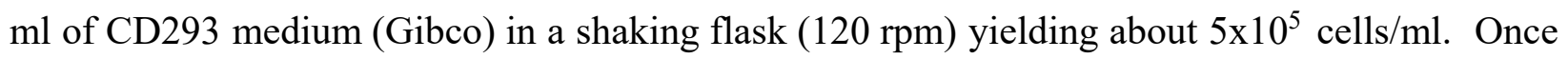
fully adapted to serum-free suspension culture, stable APT402 cells were scaled up in a 3 L spinner flask. The proteins were purified to homogeneity using IMAC, Q and SP columns and formulated in $10 \mathrm{mM}$ Tris (pH7.4)/150 mM NaCl. Enzyme fractions were monitored by absorbance at 280 nm and identified with a Malachite Green ADPase assay. Purity of recombinant proteins was determined with 4-12\% Bis-Tris SDS NuPAGE gel (Invitrogen, Waltham, MA) and Coomassie Blue staining.

APT402 was produced in CHO cells with the signal sequence of the bovine $\alpha$-lactalbumin signal peptide. The production cell lines were made by four rounds of transduction of the $\mathrm{CHO}$ parental cell line with a retrovector made by Catalent (Madison, USA) and an expression retrovector plasmid. The pooled population cell lines were cryopreserved. For 10L production, cell line CHO-S-APT402-R 4X pool was passaged every 3-4 days during the exponential growth phase for scale-up for the 10L Braun bioreactors in PFCHO LS (HyClone). Cells were inoculated 
at a cell density of approximately 300,000-400,000 cells/ml in PFCHO LS (HyClone) medium into two 10L bioreactors. Fed-batch supplements used for this study were HyClone PS307 (12\% w/v solutions), AGT CD CHO 5X Feed Medium Complete (Invitrogen, Waltham, MA), 20\% glucose solution, $200 \mathrm{mM} \mathrm{L}$-glutamine, 50X solution of L-Asparagine (15 g/L)/L-Serine (10 g/L), and 50X solution of L-Tyrosine (4 g/L)/L-Cystine (2 g/L). The harvest of 10LBRX-3380-4Xpool-001 from the $10 \mathrm{~L}$ vessel occurred on day 12 of culture. The protein was purified to homogeneity using ANX, SP and heparin columns.

\section{Apyrase assays and kinetic analysis}

Spectrophotometric assays for ADPase and ATPase activities of apyrases were performed using Malachite Green as described (43). Briefly, enzymatic reactions were conducted in $50 \mathrm{mM}$ Tris- $\mathrm{HCl}(\mathrm{pH} 7.4) / 8 \mathrm{mM} \mathrm{CaCl}_{2}$ at $37^{\circ} \mathrm{C}$. The enzymatic reaction solution $(50 \mu \mathrm{l})$ was mixed with $950 \mu \mathrm{l}$ of malachite working solution at $25^{\circ} \mathrm{C}$ for $30 \mathrm{~min}$. Inorganic phosphate release resulted in an increase of absorbance at $630 \mathrm{~nm}$, monitored using an Agilent 8453 UV-Visible spectrophotometer (Agilent, Palo Alto, CA). Estimates of kinetic parameters were determined spectrophotometrically with equimolar concentrations of APT102 at $10 \mathrm{ng} / \mathrm{ml}$ and APT402 at $18 \mathrm{ng} / \mathrm{ml}$ using unweighted nonlinear least-squares Newton-Raphson regressions to the Michaelis-Menten model.

\section{In vitro platelet aggregation assays}

Blood was collected via 23 ga. butterfly needle from a peripheral vein of healthy animals and consenting human volunteers who had not ingested aspirin for at least one week. Anticoagulation was achieved with fresh acid citrate-dextrose $(38 \mathrm{mM}$ citric acid, $75 \mathrm{mM}$ sodium citrate, $135 \mathrm{mM}$ glucose, $\mathrm{vol} / \mathrm{ml}$ of blood) or heparin $(100 \mathrm{U} / \mathrm{ml})$. Platelet-rich plasma was

obtained by centrifuging the blood at low speed $(160 \mathrm{x}$ g) for $10 \mathrm{~min}$ at room temperature. After 
the platelet-rich plasma was pipetted to a second tube, the remaining blood was centrifuged at high-speed $(1,500 \mathrm{x} \mathrm{g})$ for $15 \mathrm{~min}$ at room temperature to yield platelet-poor plasma. An aliquot of platelet-rich plasma (containing 1.0-1.2 x $10^{8}$ platelets) was preincubated for 3 min at $37^{\circ} \mathrm{C}$ in an aggregometer cuvette (light transmission aggregometer, Chrono-log, Haverton, PA) with added APT102, APT402, or isotonic Tris- buffered saline (Sigma, St. Louis, MO). Light absorption of plasma was controlled for by adding platelet-poor plasma and the total volume was adjusted to $300 \mu 1$ with Tris-buffered saline. After a 3 min preincubation, ADP was added and the aggregation response was recorded for 4-6 min.

\section{In vitro Thrombin generation assays}

Thrombin generation in citrated PRP or PPP was quantified by calibrated automated thrombography (CAT), according to methods developed by Hemker et al. (32). Aliquots of PRP or PPP were incubated with annexin V, APT102, or APT402 for $15 \mathrm{~min}$ at room temperature, and then for $5 \mathrm{~min}$ at $37^{\circ} \mathrm{C}$ in $96-$ well plates. Thrombin generation was initiated by addition of tissue factor $(0.5 \mathrm{pM})$ and $\mathrm{CaCl}_{2}(16.7 \mathrm{mM})$ and monitored in a fluorometer (Fluoroskan Ascent, Thermo Fisher Scientific, Waltham). Thrombograms (nM thrombin vs. time) were generated using the Thrombinoscope software, as were key thrombin generation parameters: lag time to onset of thrombin generation (min), peak thrombin concentration (nM), time to peak thrombin (min), and endogenous thrombin potential (ETP; integrated area under the thrombogram curve). Parameters were normalized to control samples.

\section{In vivo Methods}

All procedures involving animals were approved by the Institutional Animal Care and Use Committees at Washington University or the University of Michigan.

\section{Pharmacokinetics and pharmacodynamics in rabbits}


The time course of ATP402 protein levels in plasma was determined by intravenous administration to rabbits $(\mathrm{n}=2-3)$. APT402 was given as a single IV bolus at $0.4 \mathrm{mg} / \mathrm{kg}$ or a single IV bolus at $0.2 \mathrm{mg} / \mathrm{kg}$ followed by IV infusion at 12 or $24 \mu \mathrm{g} / \mathrm{kg} / \mathrm{min}$ for $2 \mathrm{~h}$. Blood samples were collected serially in heparinized tubes. Pharmacodynamics were assessed ex vivo by measurement of ADPase activity, ADP-induced platelet aggregation in platelet-rich plasma, and thrombin generation in platelet-poor plasma.

\section{Rabbit model of arterial thrombosis}

Electrolytic injury was induced in the carotid artery of rabbits as described previously (33). Briefly, New Zealand white rabbits weighing 3-4 kg were sedated with ketamine (20-30 mg/kg, IM) and anesthesia was maintained with oxygen-enriched room air containing 1-3\% isoflurane delivered through an endotracheal tube. Rabbits were randomized into the following 11 groups with the treatments initiated 30 min before electrolytic carotid injury and IV infusions lasting 150 min. The effective dosages for clopidogrel, enoxaparin and bivalirudin in rabbits were selected as decribed previously (44-46). The effective dosage for ticagrelor in rabbits was recommended according to the internal studies of AstraZeneca. Group $1(\mathrm{n}=10)$ : control saline IV infusion for 2h; Group 2 ( $\mathrm{n}=6$ ): hydroxypropyl methylcellulose control (HPMC) oral and IV saline infusion; Group 3 ( $\mathrm{n}=6$ ): clopidogrel at $4 \mathrm{mg} / \mathrm{kg}$ oral and IV saline infusion; Group $4(\mathrm{n}=6)$ : enoxaparin at $0.7 \mathrm{mg} / \mathrm{kg}$ IV bolus followed by $1 \mathrm{mg} / \mathrm{kg} / \mathrm{h}$ IV infusion; Group 5 ( $\mathrm{n}=6$ ): bivalirudin at $5 \mathrm{mg} / \mathrm{kg} \mathrm{IV}$ bolus followed by $5 \mathrm{mg} / \mathrm{kg} / \mathrm{h}$ IV infusion; Group $6(\mathrm{n}=6)$ : APT102 at $0.3 \mathrm{mg} / \mathrm{kg}$ IV bolus $(\mathrm{n}=2)$ or $1.0 \mathrm{mg} / \mathrm{kg}$ IV bolus ( $\mathrm{n}=4$ ); Group 7: ticagrelor at $10 \mathrm{mg} / \mathrm{kg}$ in HPMC oral and IV saline infusion; Group 8: Ticagrelor at $10 \mathrm{mg} / \mathrm{kg}$ in HPMC oral plus bivalirudin at $5 \mathrm{mg} / \mathrm{kg}$ IV bolus followed by $5 \mathrm{mg} / \mathrm{kg} / \mathrm{h}$ IV infusion; Group 9 (n=6): APT402 at $0.2 \mathrm{mg} / \mathrm{kg}$ IV bolus followed by $4 \mu \mathrm{g} / \mathrm{kg} / \mathrm{min}$ IV infusion for 2h; Group 10 (n=6): APT402 at $0.2 \mathrm{mg} / \mathrm{kg}$ IV bolus followed by $12 \mu \mathrm{g} / \mathrm{kg} / \mathrm{min} \mathrm{IV}$ 
infusion for 2h; Group $11(\mathrm{n}=6)$ : APT402 at $0.2 \mathrm{mg} / \mathrm{kg}$ IV bolus followed by $24 \mu \mathrm{g} / \mathrm{kg} / \mathrm{min} \mathrm{IV}$ infusion for $2 \mathrm{~h}$.

Electrolytic injury to the carotid was induced at $\mathrm{t}=0$ by application of $250 \mu \mathrm{A}$ of anodal current to the indwelling needle electrode with use of a $9 \mathrm{~V}$ battery for $2 \mathrm{~h}(36)$. Current was increased to $300 \mu \mathrm{A}$ after $30 \mathrm{~min}$ and to $350 \mu \mathrm{A}$ after $1 \mathrm{~h}$. Blood flow was monitored continuously and recorded at the time of blood sampling. Blood samples were obtained for assays and bleeding times were measured at baseline, $30 \mathrm{~min}, 1 \mathrm{~h}$ and $2 \mathrm{~h}$ after the onset of current. After $2 \mathrm{~h}$, the injured carotid artery was excised and the thrombus carefully removed and weighed.

\section{In vivo imaging of fluorescent dye-labeled thrombi by fluorescence molecular tomography}

A near infra-red (NIR) fluorescent dye (LS288, Ex/Em 773/793) in methanol was conjugated ( 1:1) to the functional amines of APT402 (and APT102 as a control) and purified. A custom built, fiber-based, portable, video-rate system was used for in vivo imaging as described (34). Briefly, a flexible imaging pad $(3 \mathrm{~cm}$ x $3 \mathrm{~cm}$ ) containing 12 sources $680 \mathrm{~nm} 20 \mathrm{~Hz}$, and $710 \mathrm{~nm} 17 \mathrm{~Hz}$ laser diodes for excitation and absorption, respectively, was taped perpendicular to the skin incision over the carotid arteries to provide dynamic concurrent acquisition of tomographic data from both the injured and contralateral non-injured carotid artery used as a reference. After a $30 \mathrm{~min}$ stabilization period, the NIR-labeled APT402 (or NIR labeled-APT102) together with a bolus dose of non-labeled APT402 (or APT102) was given IV and an IV infusion of unlabeled APT402 was started. Anodal current was applied to the carotid needle electrode to initiate thrombosis $30 \mathrm{~min}$ after the bolus of APT102 or APT102. Carotid blood flow was monitored continuously with the electromagnetic probe. Accumulation of the labeled drug was monitored serially with the FMT probe. After $2 \mathrm{~h}$, the carotid thrombus was collected, weighed and frozen in OCT media to observe the bound NIR-labeled drug in 10 micron sections cut on a cryostat and mounted on glass slides. 
Epifluorescence was imaged using a Cy7 filter with excitation at 710/75 and emission at 810/90 using a dichroic 750LP film and exposure time of 20s.

\section{Murine model of venous thrombosis}

In the mouse venous thrombosis model, endothelial damage promoted a thrombogenic environment and subsequent, predictable thrombus formation, as described previously $(35,36)$. Briefly, a current of $250 \mu \mathrm{A}$ delivered by a needle electrode placed in the inferior vena cava for 15 min results in the formation of free radicals of electrolysis that activate the endothelial surface of the vessel. In the acute thrombotic study, mice were randomized into the following four groups (n $=10$ /group) and treatments were initiated 15 min after induction of injury: Control: Placebo control on days 1 and 2; enoxaparin: $6 \mathrm{mg} / \mathrm{kg} /$ day SC on days 1 and 2; APT402 low dose (LD): $0.2 \mathrm{mg} / \mathrm{kg}$ IP bolus followed by $0.5 \mu \mathrm{g} / \mathrm{kg} / \mathrm{min}$ SC infusion for $48 \mathrm{~h}$; APT402 high dose (HD): 0.2 $\mathrm{mg} / \mathrm{kg}$ IP bolus followed by $1.5 \mu \mathrm{g} / \mathrm{kg} / \mathrm{min} \mathrm{SC}$ infusion for $48 \mathrm{~h}$. Thrombi were removed and weighed $48 \mathrm{~h}$ post-thrombus induction by scientists who were blinded to the treatment groups, as described previously $(28,29)$. Bleeding time was measured by making a small transaxial incision of the tail, which was then immersed in $37^{\circ} \mathrm{C}$ PBS and blood flow visually observed and timed until cessation or for a maximum of 5 min. Coagulation tests (PT, aPTT, TCT) were run according to manufacturer's instructions (Dade Diagnostics, Miami, FL, USA) at baseline and $48 \mathrm{~h}$ post thrombus induction.

\section{Statistical analysis}

All data are presented as the mean $\pm \mathrm{SEM}$ or $\mathrm{SD}$ as indicated. Gaussian distribution was assessed by the D'Agostino-Pearson normality test. Two-group comparisons were performed with Student's two-tailed, $t$ test. One-way ANOVA with Tukey's post hoc test was used to perform multiple group comparisons. Serial data were analyzed using a General Linear Model for Repeated Measures 
ANOVA (SigmaStat v.3.11 Systat Software Inc,). Statistical differences with two-tailed probability values of $P<0.05$ were considered significant. All data were analyzed using Excel (Microsoft). 


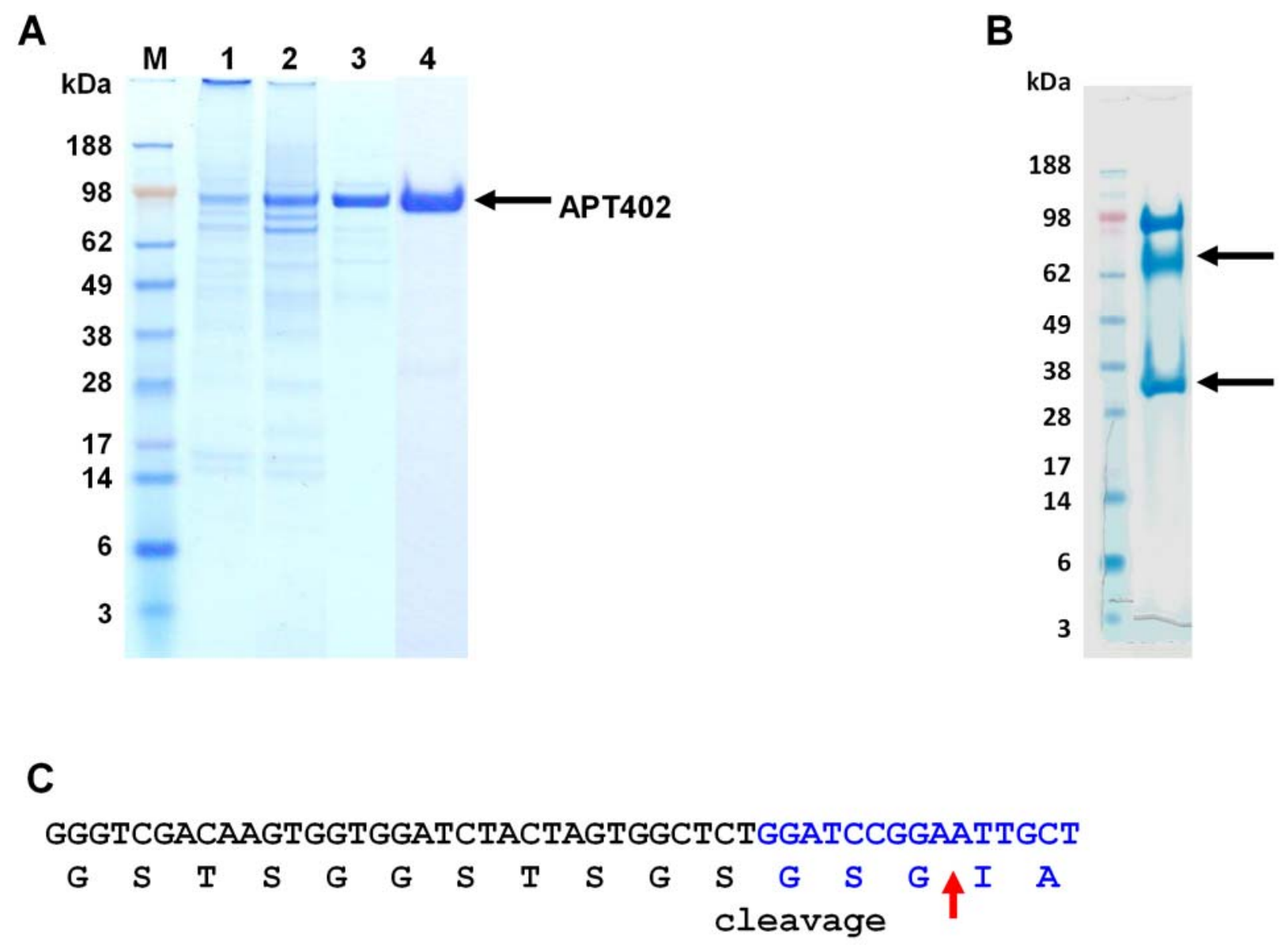

fig S1. A. Purification of apyrase-annexin fusion protein V1 from HEK 293T cell supernatant. Proteins were separated on 4-12\% SDS gels. The fusion protein (indicated by the arrow) from 1. Supernatant; 2. Chromatography on IMAC column; 3. Chromatography on Q column; 4. Chromatography on SP column. B. Degradation of the purified protein in the linker region. Arrows indicates degraded products. C. Cleavage site sequence in the linker region. 

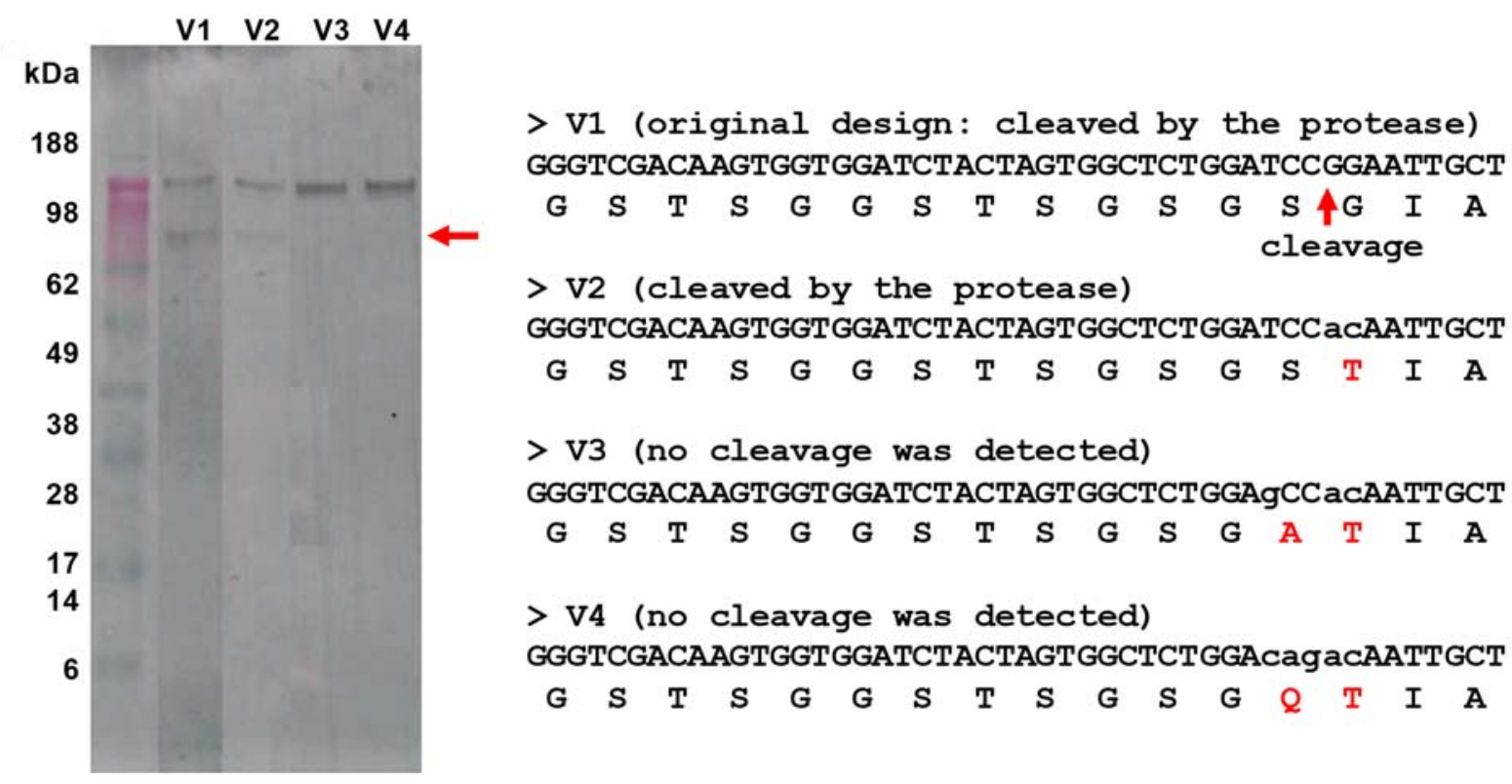

fig. S2. Engineering of protease-resistant fusion proteins detected with Western analysis. The degraded product (left: arrow) was detected for V1 and V2 but not V3 or V4. Mutated residues are highlighted in red (right). 


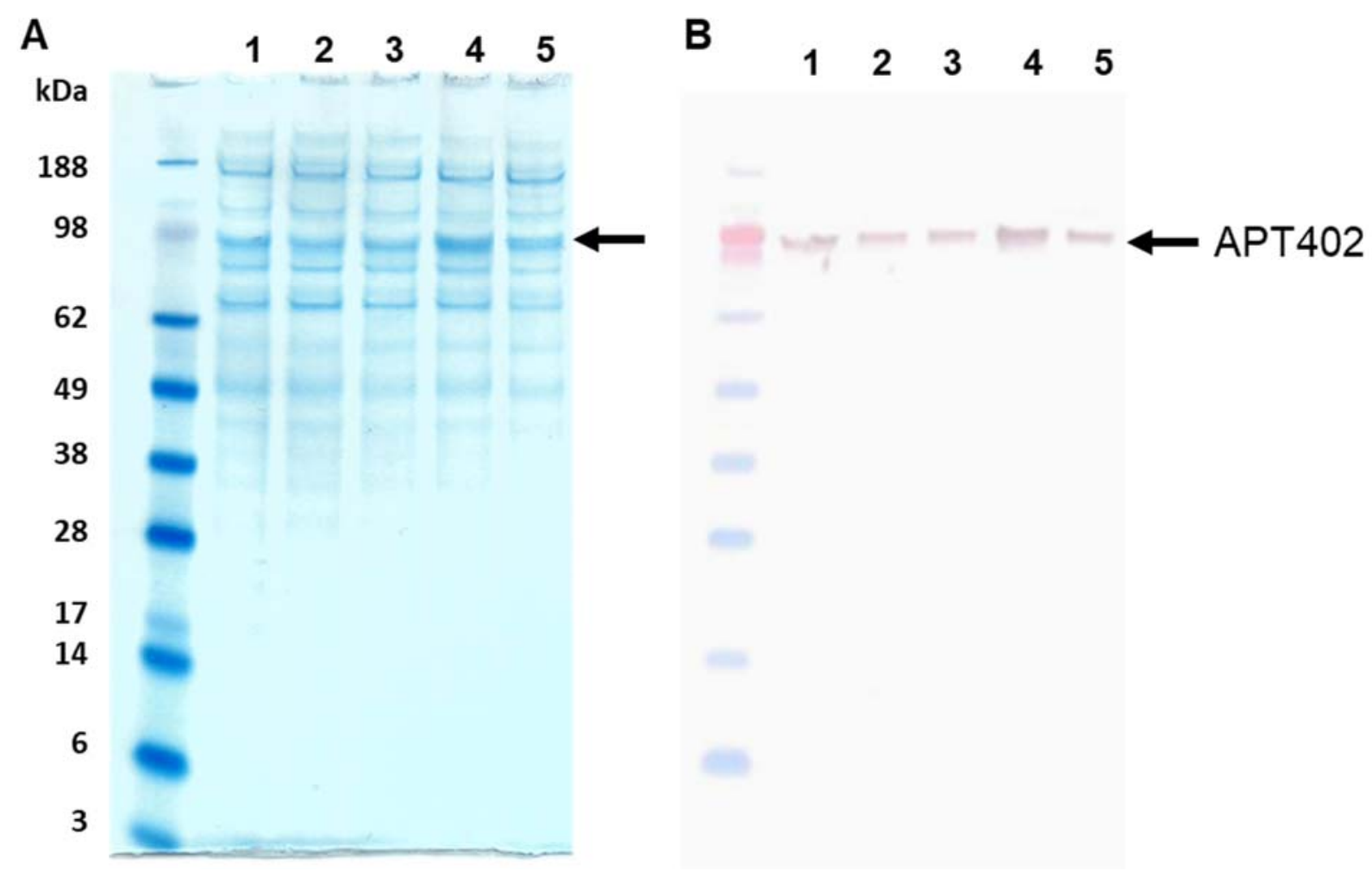

fig. S3. Effect of linker lengths on expression level of the annexin APT102 fusion proteins (arrow). The flexible linker with 20 AA resulted in the highest expression. Lane 1. 5 AA flexible linker: GSTSG; Lane 2. 10 flexible AA linker: (GSTSG)x2; Lane 3. 15 flexible AA linker: (GSTSG)x3; Lane 4. 20 AA flexible linker: (GSTSG)x4; Lane 5. 9 AA rigid linker: PAPAPAPAP. A, stained with Comassie blue; B. Western blot analysis. 


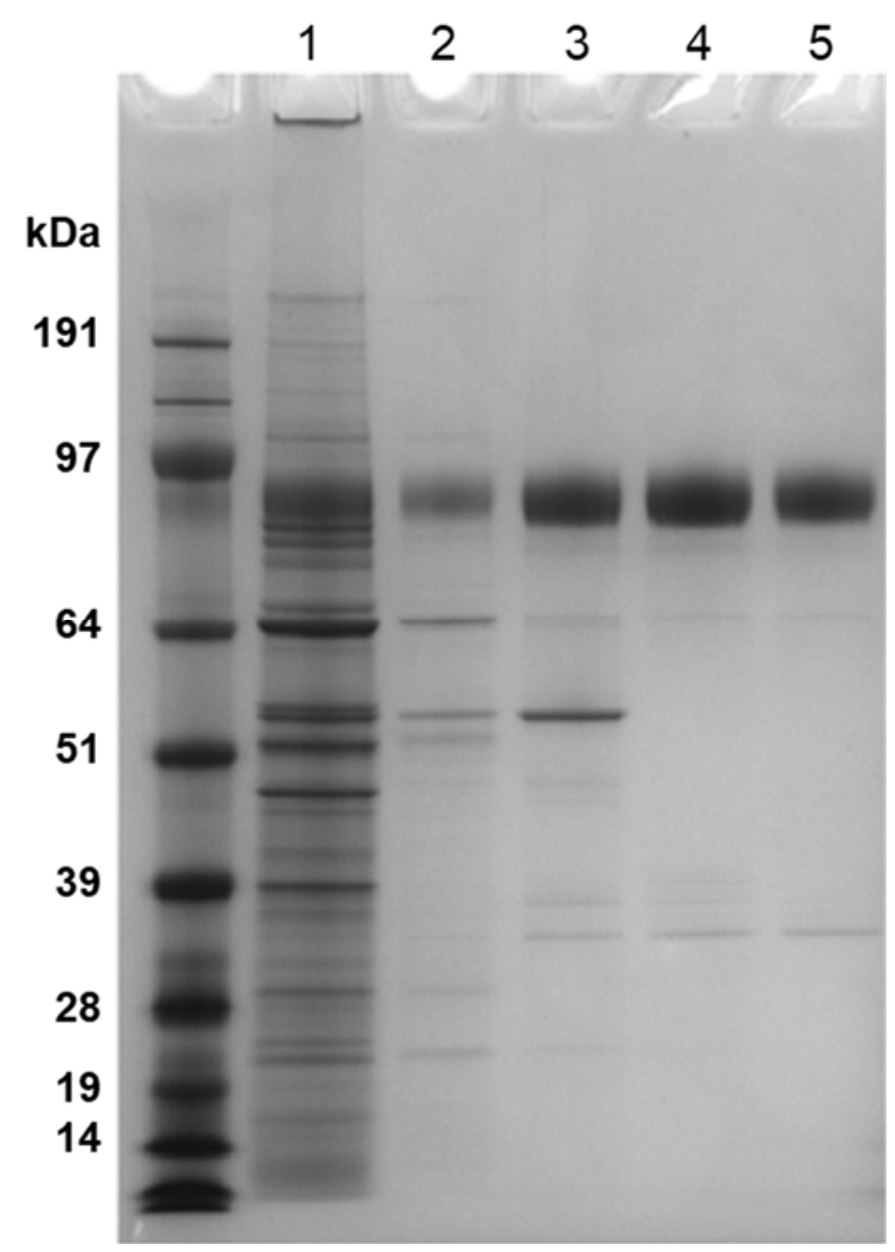

fig S4. Purification of APT402 from CHO cell supernatant. Lane 1. Clarified media; Lane 2. ANX, Lane 3. SP, Lane 4. Heparin, Lane 5. Formulated. 

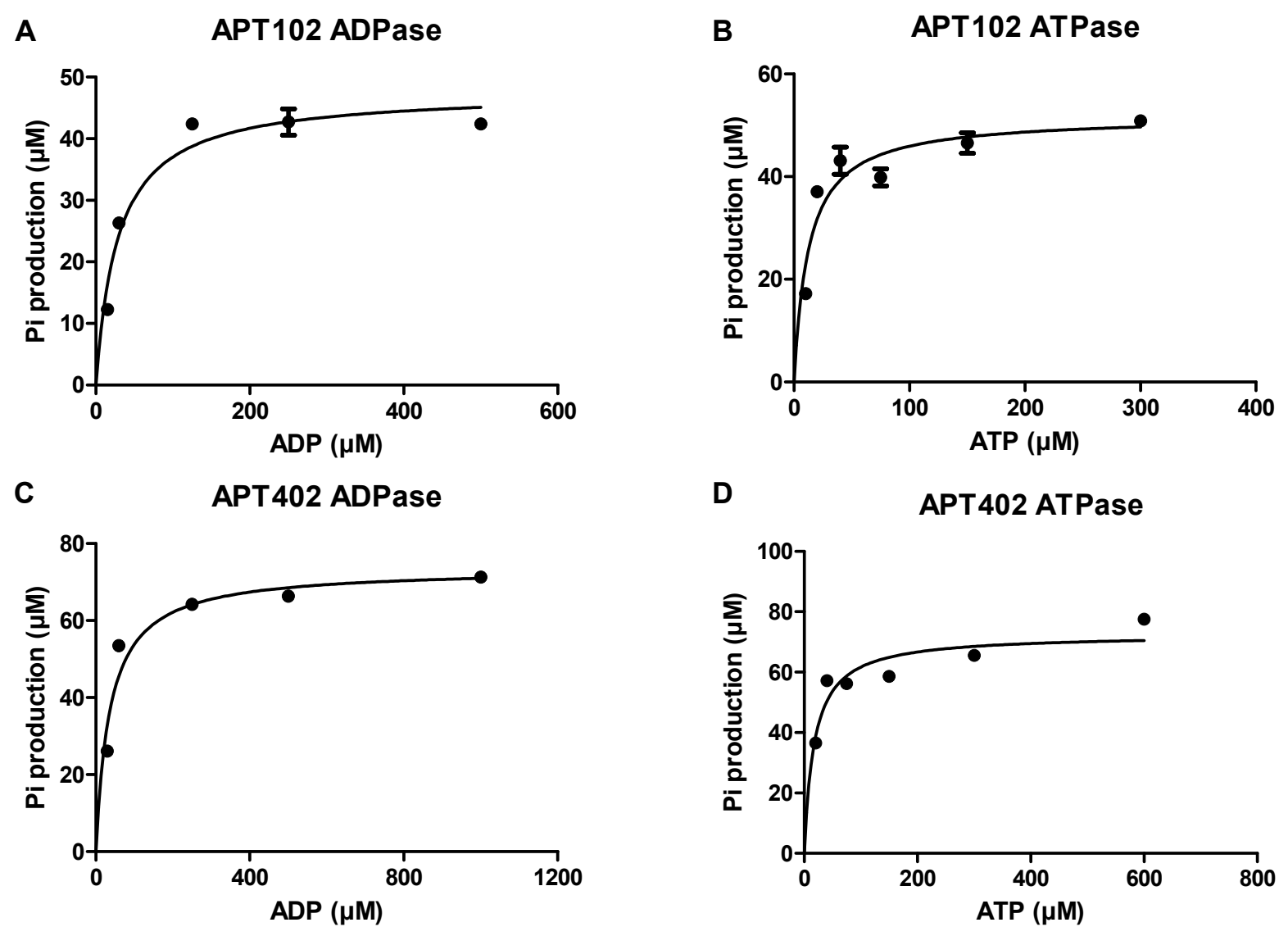

fig. S5. Comparable ADPase and ATPase kinetic activities of APT102 vs APT402. Both enzymes exhibit typical Michaelis-Menten saturation curves. (A) ADPase of APT102. (B) ATPase of APT102. (C) ADPase of APT402. (D) ATPase of APT402. 

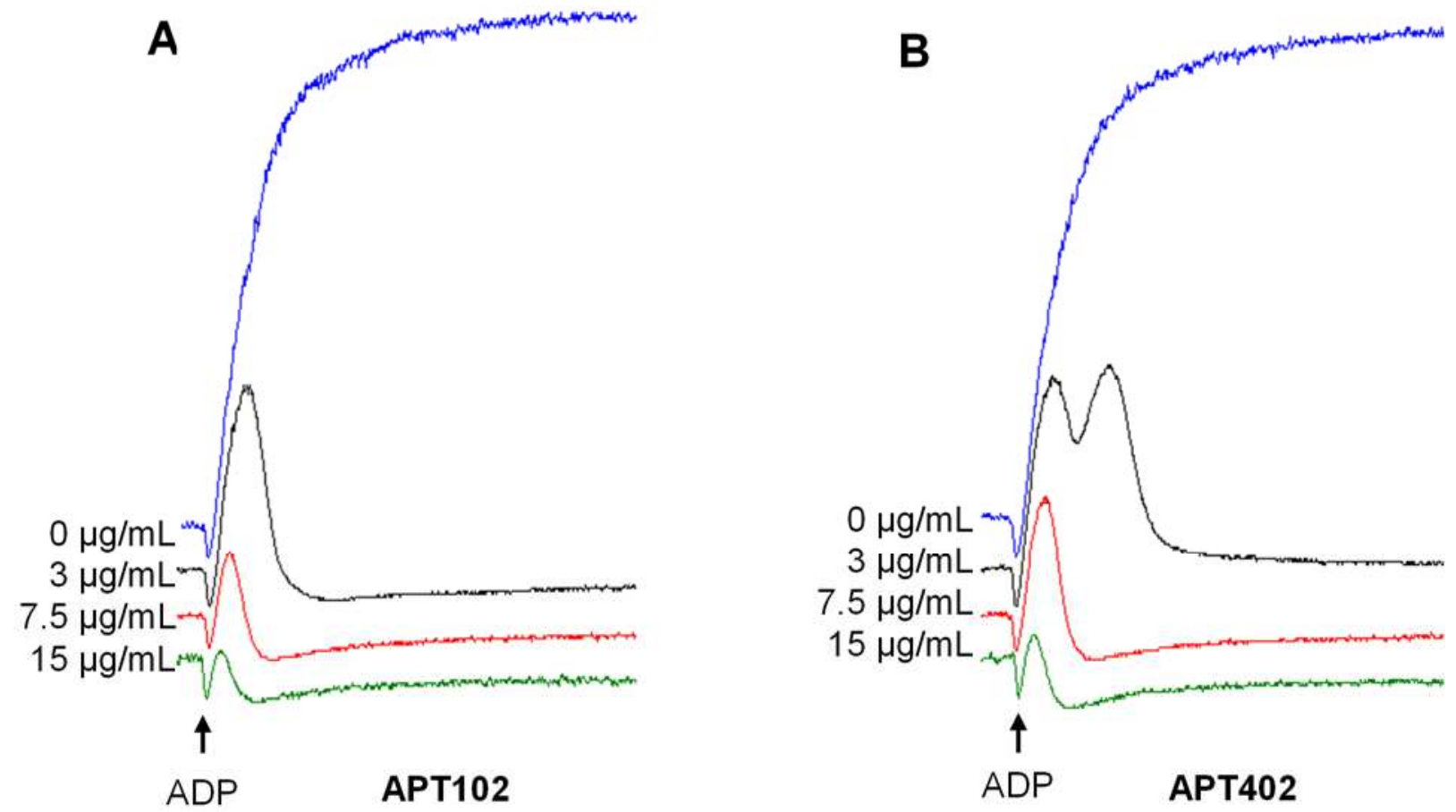

fig. S6. Comparable inhibition of ADP-induced human platelet aggregation with APT102 vs APT402. $\mathrm{X}$ axis is the assay time (6 min duration), $\mathrm{Y}$ axis is light transmission, with an upward curve indicating platelet aggregation. The arrows indicate the addition of ADP. APT102 or APT402 was added 3 minutes before ADP stimulation. (A) APT102 dose-dependently inhibited platelet aggregation induced by $5 \mu \mathrm{M}$ ADP. (B) APT402 dose-dependently inhibited platelet aggregation induced by $5 \mu \mathrm{M}$ ADP. 


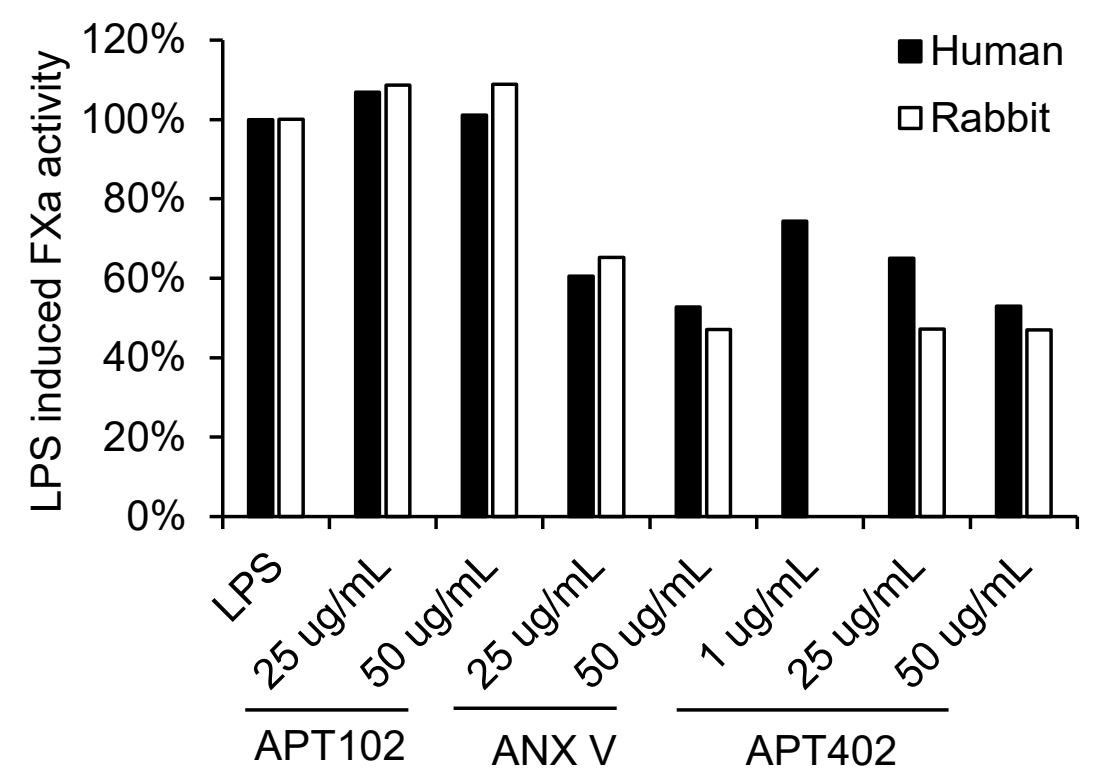

fig. S7. Comparable inhibition of LPS-induced factor X (FX) activation in rabbit and normal human blood cells by APT402 vs annexin V. Peripheral blood mononuclear cells were incubated with LPS $(1 \mathrm{mg} / \mathrm{ml})$ to induce tissue factor expression and FX activation was measured in the presence of FVII, FX and chromogenic substrate S2765. APT102 was not effective. 

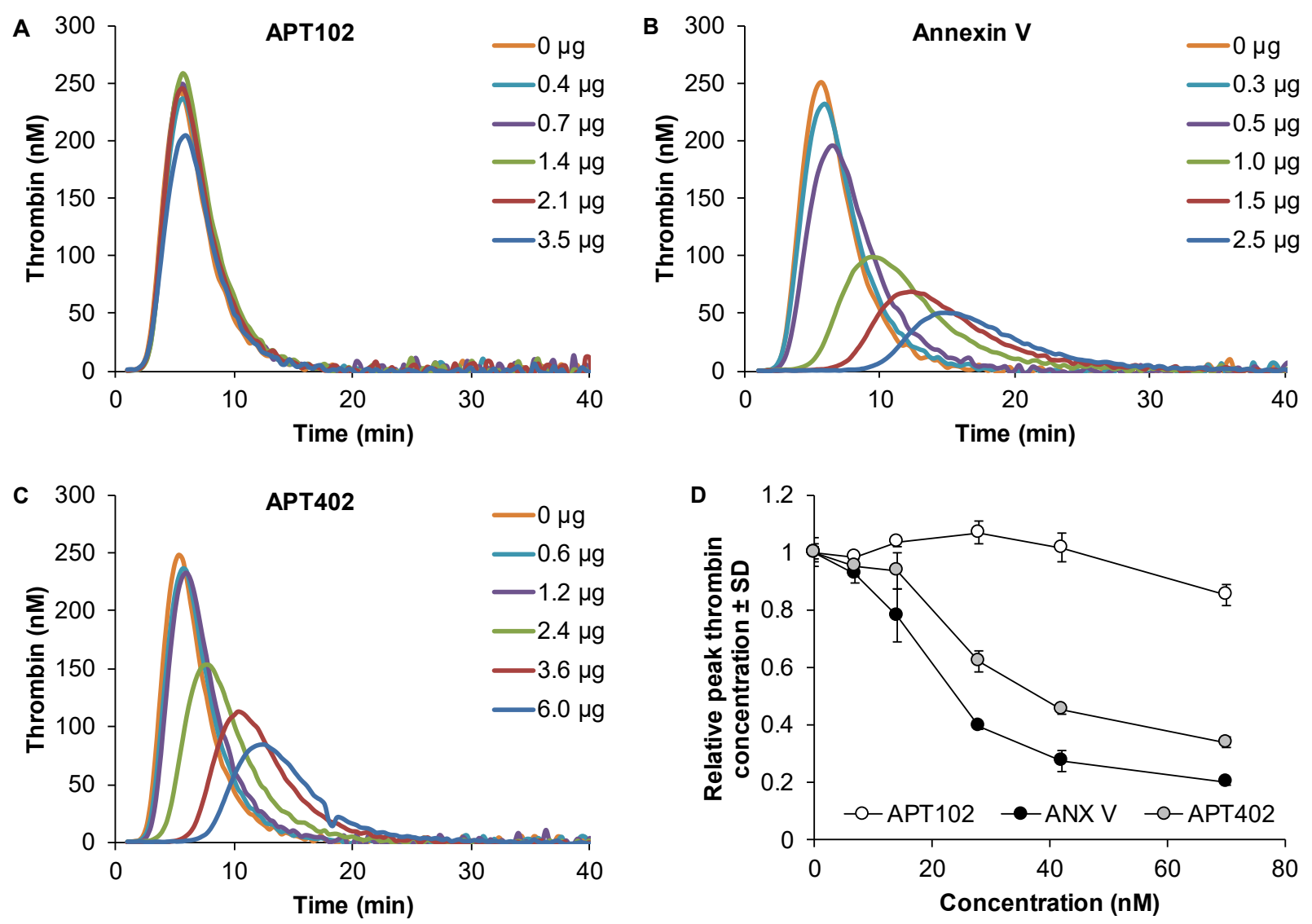

fig. S8. Comparable effects of APT102 (A), annexin V (B), and APT402 (C, D) on attenuation of thrombin generation in human platelet poor plasma. Annexin V and APT402 dose-dependently inhibited thrombin generation, while APT102 was not effective. 


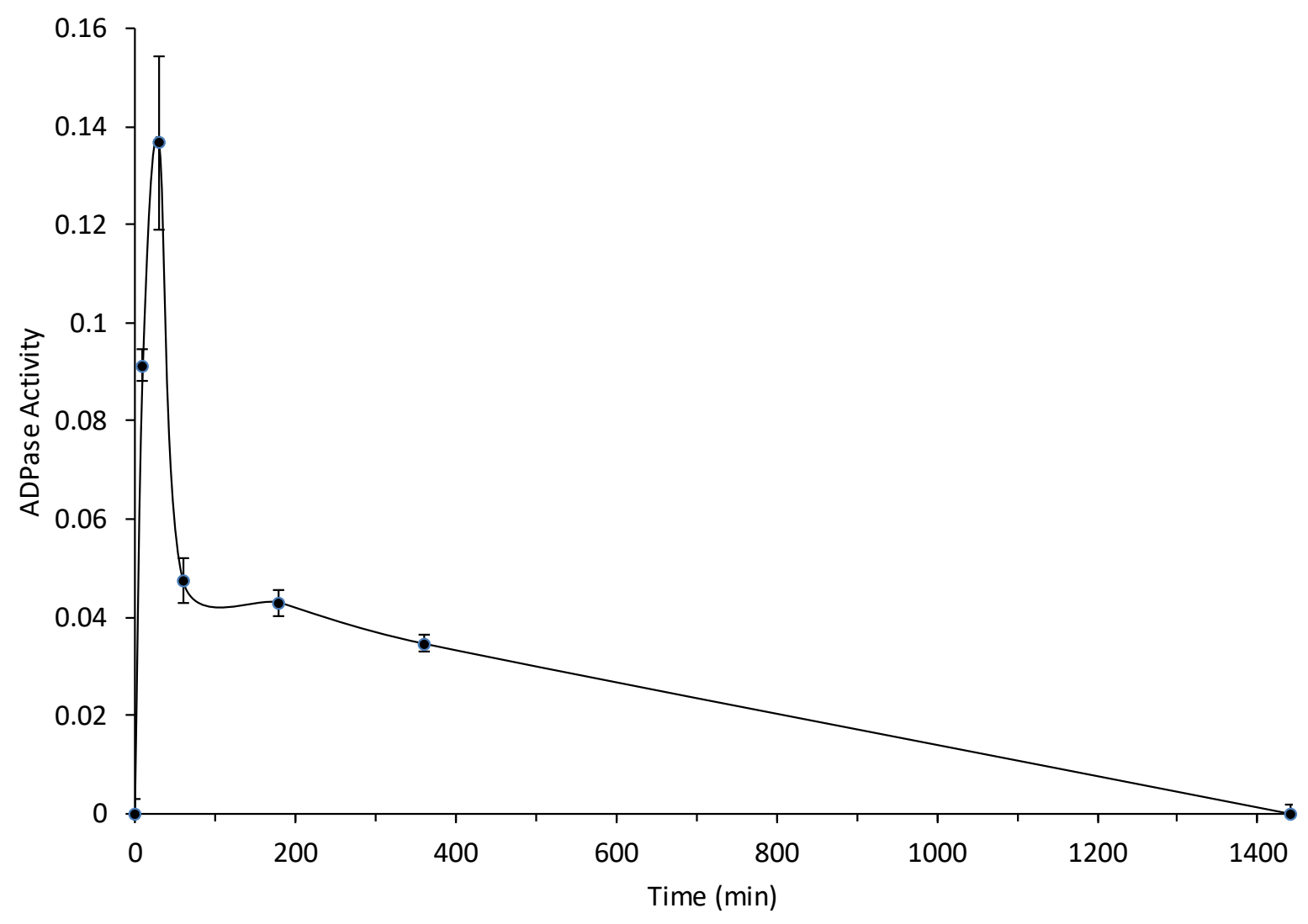

fig. S9. Pharmacokinetic analysis of APT402 in rabbits $(n=2)$ after an IV bolus injection of 0.4 $\mathrm{mg} / \mathrm{kg}$. The distribution phase and elimination half-life (t//2) of APT402 were $30 \mathrm{~min}$ and $6 \mathrm{~h}$, respectively, 
a)

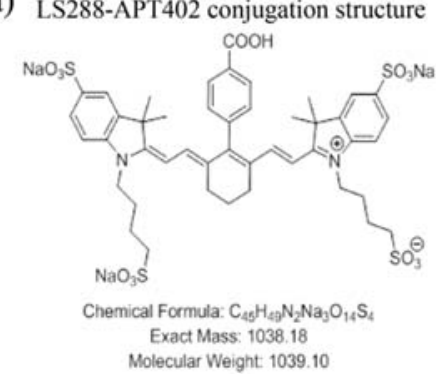

d)

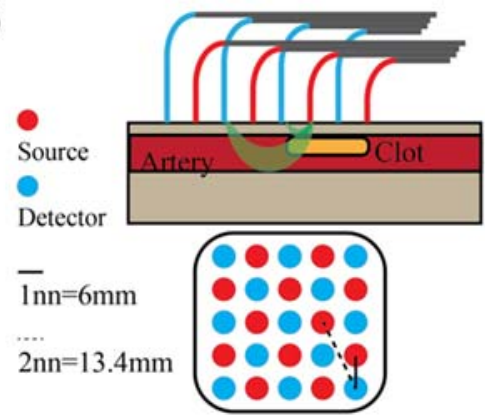

b)

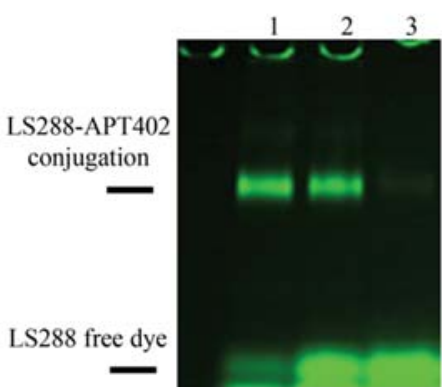

e)

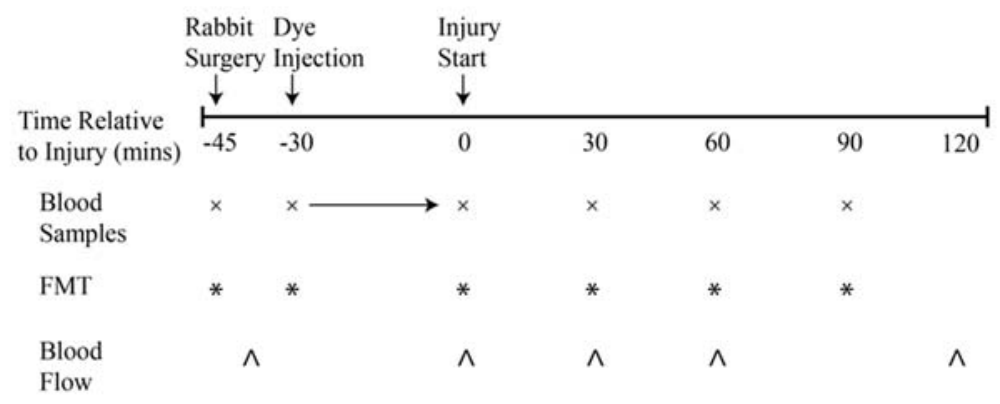

fig. S10. Conjugation of the APT102-annexin V (APT402) with NIR Dye LS288, Surgery, and FMT System. a) The structural formula of LS288 in MeOH (Ex/Em=773/793nm). b) Western Blot Lane 1: Purified LS288-APT402; Lane 2: Reaction mixture; Lane 3: free LS288 dye. c) Rabbit preparation to study evolving arterial thrombus (33). The right carotid was injured using a transluminal electrode. To prevent stroke from thrombi, an arteriovenous shunt was placed between the right carotid artery and the jugular vein. Blood flow was measured using a Doppler probe around the artery proximal to the needle. d) The FMT imaging pad was placed perpendicular to the injured and control uninjured artery and held in place with tape. Source fibers (red) emitted the excitation light while detector fibers (blue) collected the emission light from the probe. Measurements at multiple distances provided 3D images of the artery and clot (34). e) Experiment timeline. All times are noted relative to the start of the injury. A tracer amount of dye was injected together with the bolus dose of APT102 or APT402 30 min before injury and data was collected for 90 min post-injury as noted. 


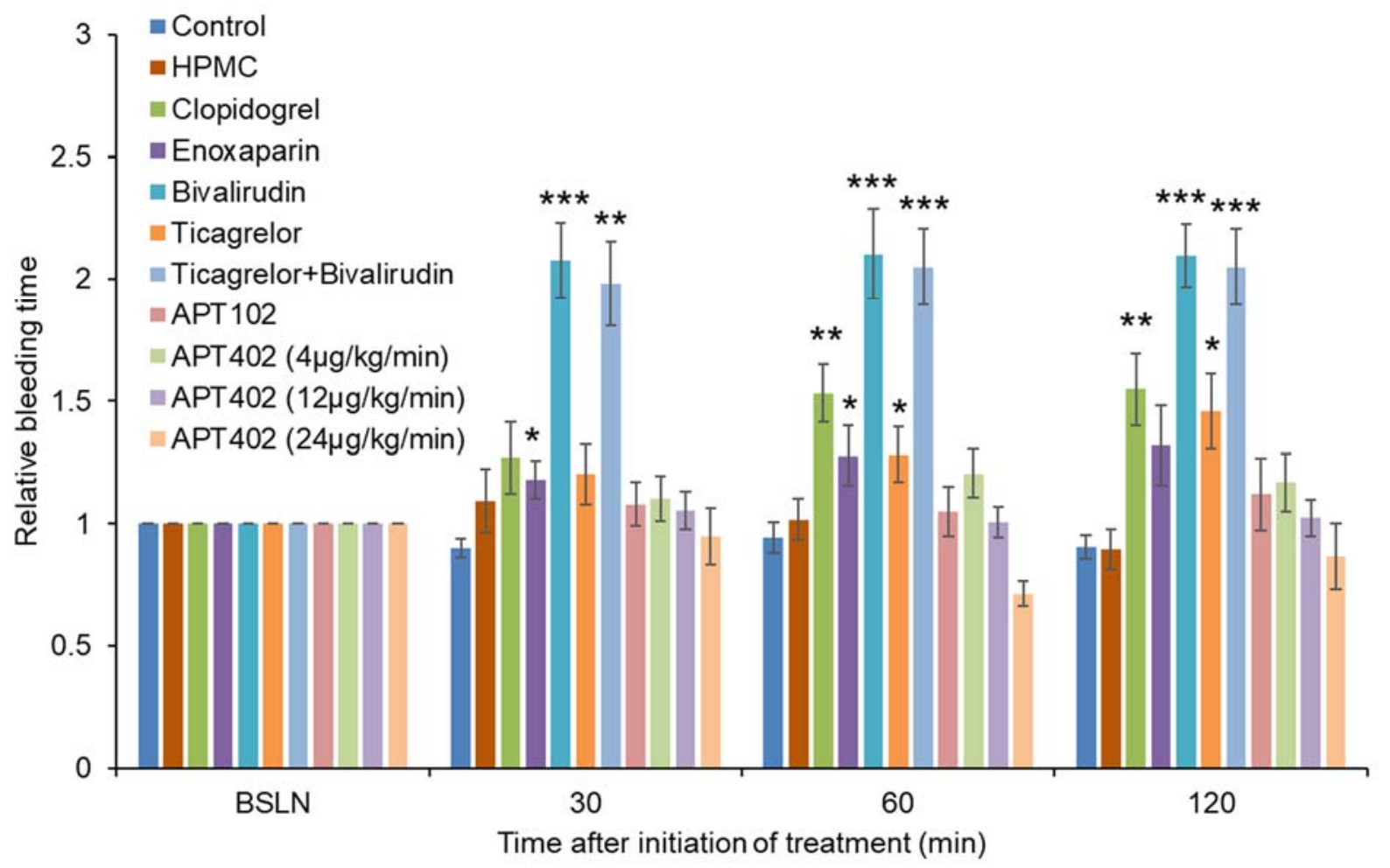

fig. S11. APT402 did not prolong bleeding time (BT) in the rabbit during arterial injury at doses that completely prevented occlusion. BT was not prolonged by HPMC vehicle, saline, or APT102, but clopidogrel, enoxaparin, bivalirudin, ticagrelor, alone or in combination with bivalirudin, all significantly prolonged BT. Measurements were stopped and the wound cauterized after $5 \mathrm{~min}$. $* \mathrm{p}<0.05 ; * * \mathrm{p}<0.01, * * * \mathrm{p}<0.001$. 


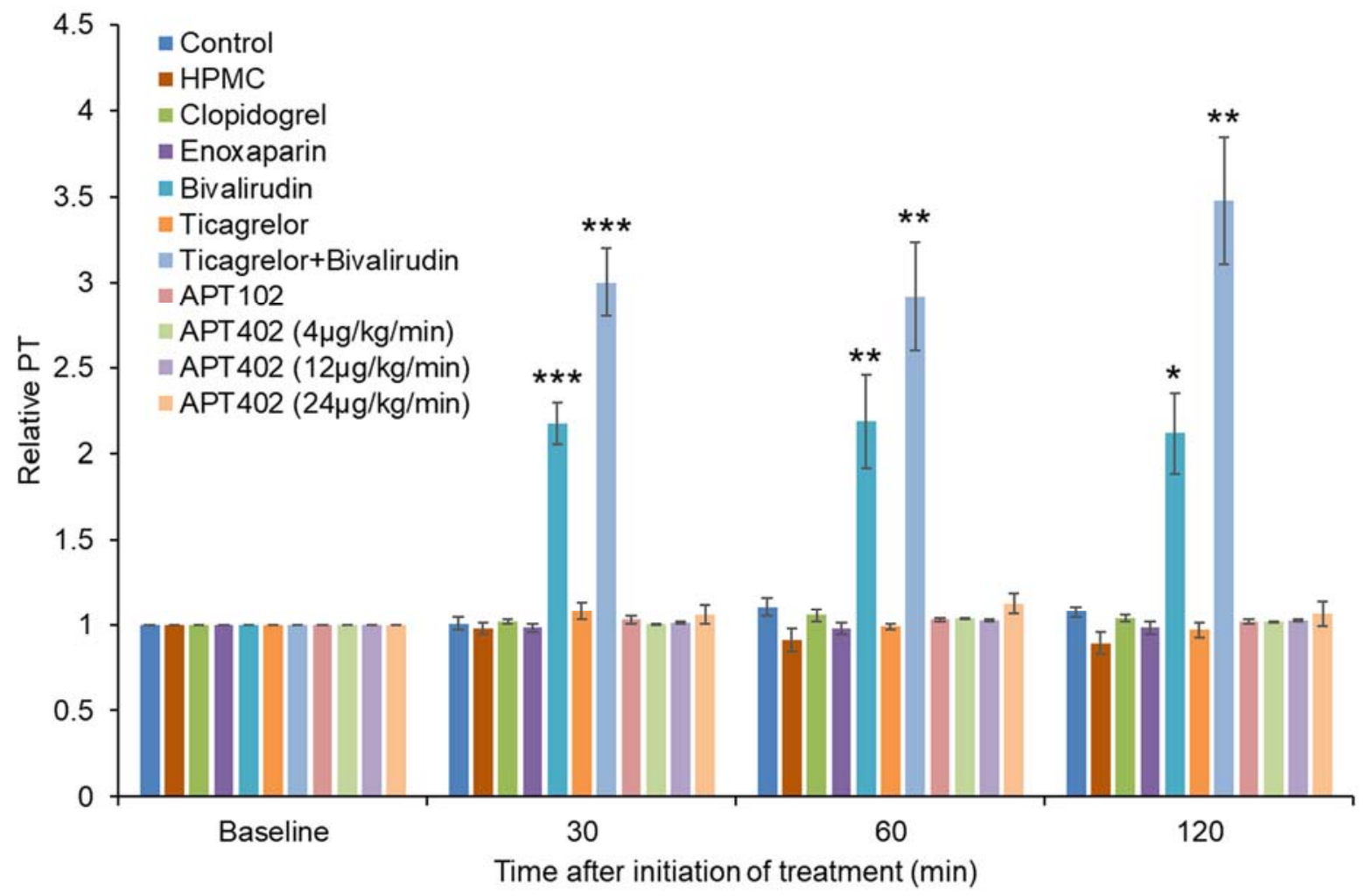

fig. S12. APT402 did not prolong prothrombin time (PT) in the rabbit during arterial injury and thrombosis at doses that completely prevented occlusion. PT was not prolonged by HPMC or saline as controls, clopidogrel, ticagrelor, or APT102, but was significantly increased in rabbits given bivalirudin, alone or in combination with ticagrelor. ${ }^{*} \mathrm{p}<0.05 ;{ }^{*} \mathrm{p}<0.01,{ }^{* * *} \mathrm{p}<0.001$. 


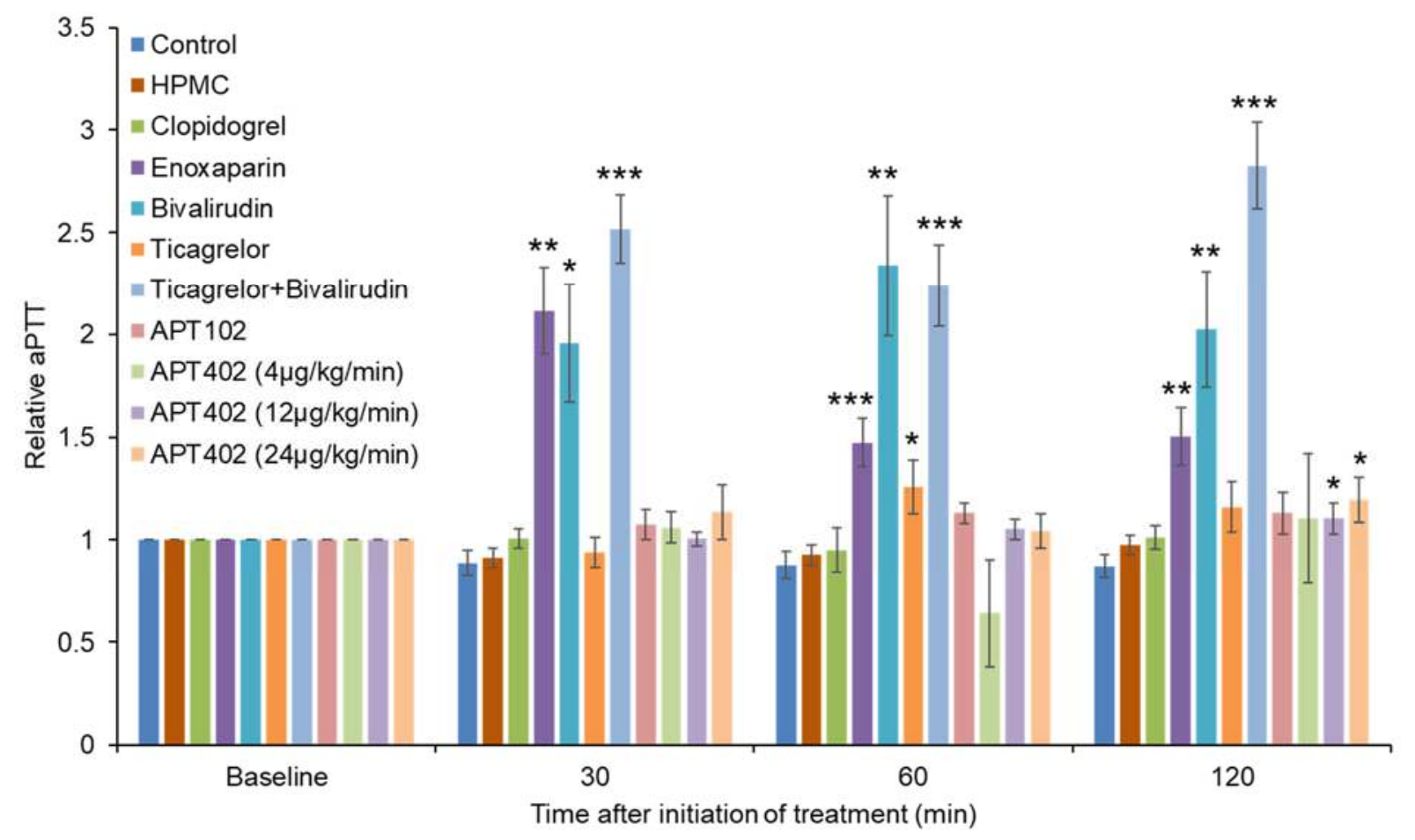

fig. S13. APT402 did not prolong activated partial thromboplastin time (aPTT) in the rabbit during arterial injury and thrombosis at doses that completely prevented occlusion. HPMC and saline control, clopidogrel, and APT102 did not affect aPTT while enoxaparin, bivalirudin, ticagrelor, alone or in combination with bivalirudin significantly increased aPTT. ${ }^{*} \mathrm{p}<0.05 ;{ }^{*} \mathrm{p}<0.01$, $* * * \mathrm{p}<0.001$. 


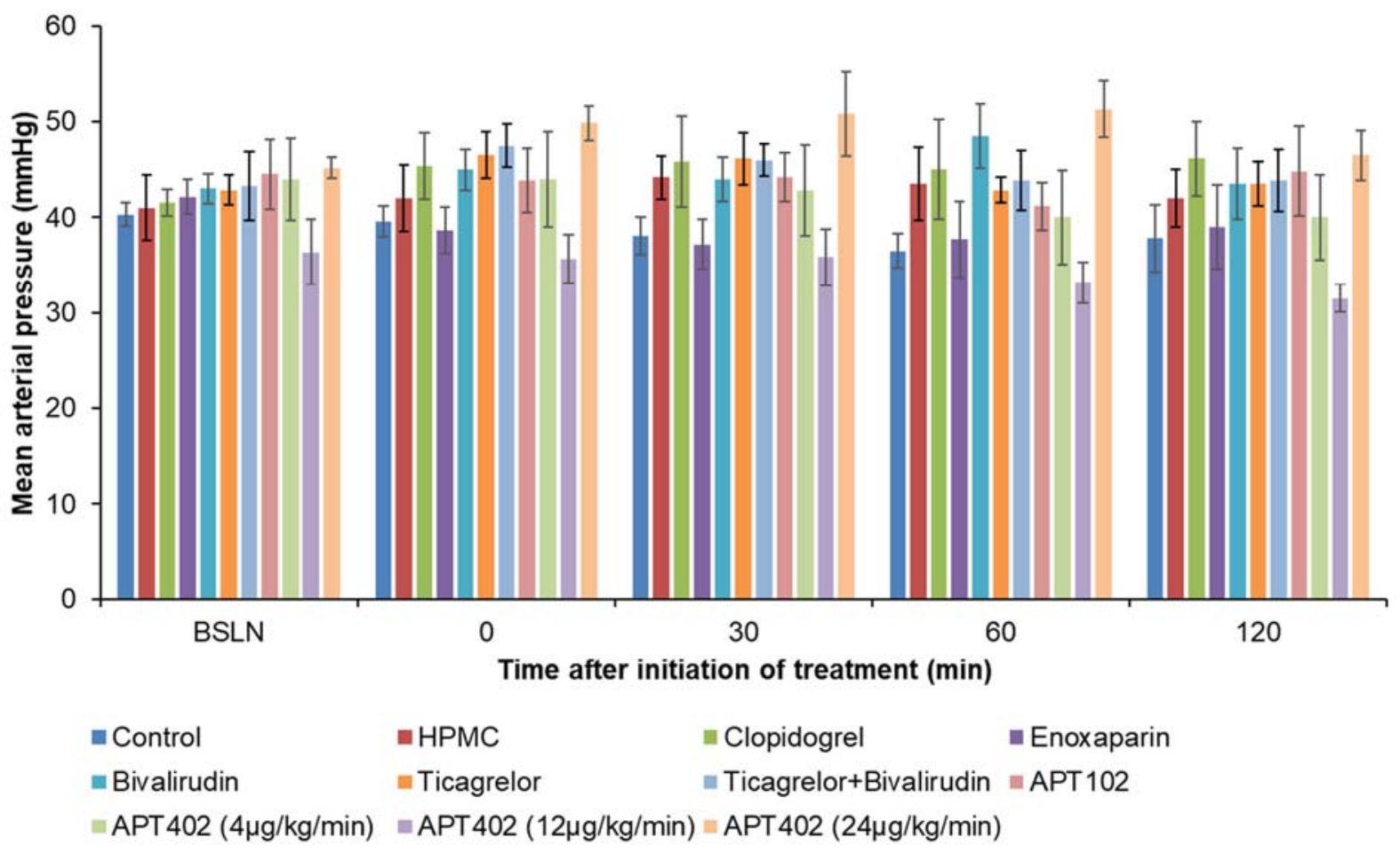

fig. S14. APT402 at effective antithrombotic doses, as well as other treatments, did not affect mean arterial pressure $(\mathrm{mmHg})$ in the rabbit model of arterial thrombosis. 


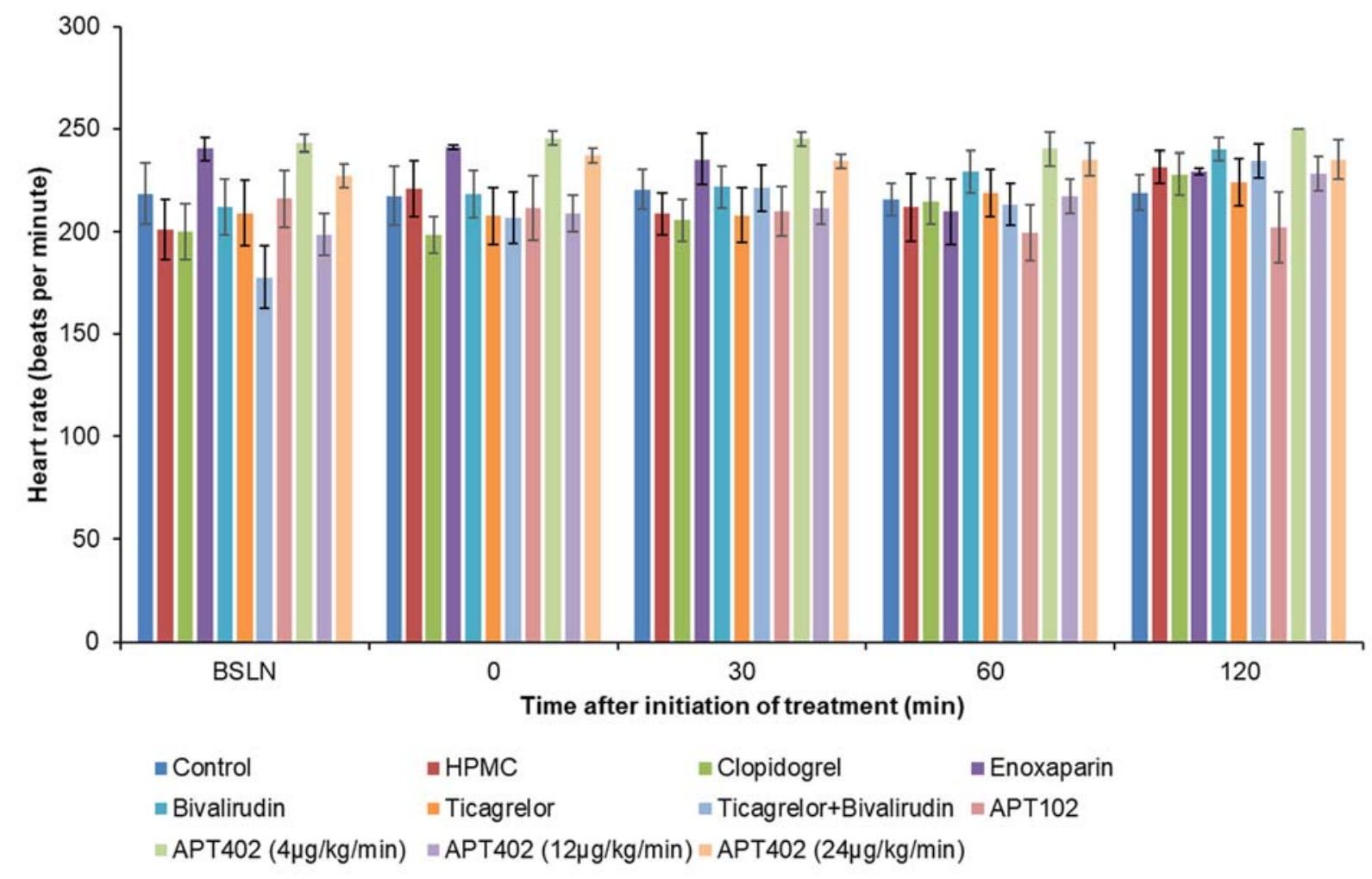

fig. S15. APT402 at effective antithrombotic doses, as well as other treatments, did not affect heart rate $(\mathrm{BPM})$ in the rabbit model of arterial thrombosis. 

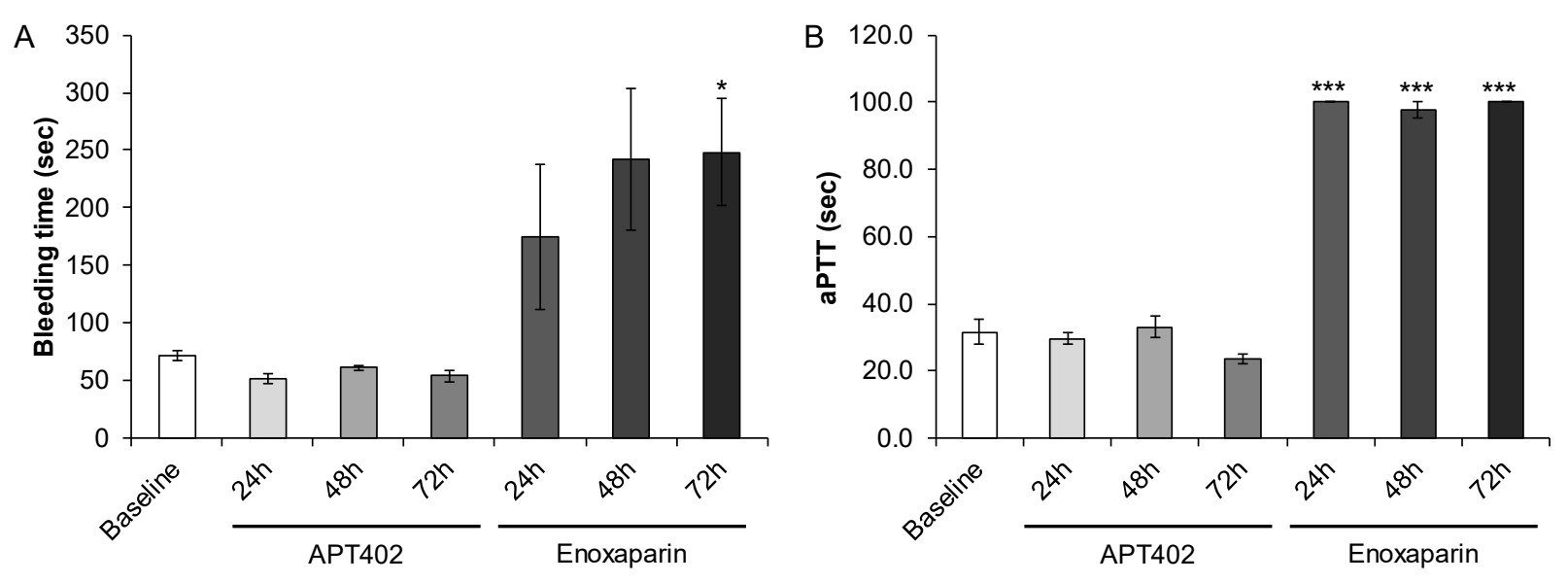

fig. S16. APT402 did not increase bleeding risk while enoxaparin increased bleeding time and induced systemic hypocoagulation in healthy mice. Mice were treated for two days with APT402 at $0.2 \mathrm{mg} / \mathrm{kg}$ IP followed by a $48 \mathrm{~h}$ infusion at $0.09 \mathrm{mg} / \mathrm{kg} / \mathrm{min} \mathrm{SC}$, or enoxaparin at $6 \mathrm{mg} / \mathrm{kg} / \mathrm{day}$ SC. Endpoints were measured at 24, 48 , and $72 \mathrm{~h}$ after initiation of administration. $\mathrm{n}=10$ for APT402 at each timepoint; $\mathrm{n}=3-6$ for enoxaparin. ${ }^{*} \mathrm{p}<0.05 ; * * * \mathrm{p}<0.001 . \mathrm{X}$-axis is the time after treatment. 
table S1. Kinetic parameters of APT102 and APT402 toward ADP and ATP. All standard errors are $<20 \%$ of the estimate.

\begin{tabular}{|c|c|c|c|c|c|c|c|}
\hline \multirow[b]{2}{*}{ Apyrase } & \multicolumn{3}{|c|}{ ADP } & \multicolumn{3}{|c|}{ ATP } & \multirow{2}{*}{$\begin{array}{r}\text { Preference } \\
\text { ADPase/ATPase }\end{array}$} \\
\hline & $\begin{array}{c}K_{\mathrm{m}} \\
(\mu \mathrm{M})\end{array}$ & $\begin{array}{c}k_{\text {cat }} \\
\left(\mathrm{sec}^{-1}\right)\end{array}$ & $\begin{array}{c}k_{\text {cat }} / K_{\mathrm{m}} \\
\left(\mu \mathrm{M}^{-1} \mathrm{sec}^{-1}\right)\end{array}$ & $\begin{array}{c}K_{\mathrm{m}} \\
(\mu \mathrm{M})\end{array}$ & $\begin{array}{c}k_{\text {cat }} \\
\left(\mathrm{sec}^{-1}\right)\end{array}$ & $\begin{array}{c}k_{\text {cat }} / K_{\mathrm{m}} \\
\left(\mu \mathrm{M}^{-1} \mathrm{sec}^{-1}\right)\end{array}$ & \\
\hline APT102 & 28.85 & 172.25 & 5.97 & 12.67 & 186.98 & 14.76 & 0.40 \\
\hline APT402 & 36.74 & 215.8 & 5.87 & 17.63 & 212.72 & 12.07 & 0.49 \\
\hline
\end{tabular}


table S2. EC E $_{50}$ of APT102 and APT402 for inhibition of ADP $(20 \mu \mathrm{M})$-induced human platelet aggregation ( $\left.\mathrm{n}=2-3\right)$.

\begin{tabular}{ccccc}
\hline \multirow{2}{*}{ PRP plasma } & \multicolumn{2}{c}{ Heparinized } & \multicolumn{2}{c}{ Citrated } \\
\cline { 2 - 5 } & $\mathrm{EC}_{50}(\mu \mathrm{g} / \mathrm{mL})$ & $\mathrm{EC}_{50}(\mathrm{nM})$ & $\mathrm{EC}_{50}(\mu \mathrm{g} / \mathrm{mL})$ & $\mathrm{EC}_{50}(\mathrm{nM})$ \\
\hline APT102 & 0.08 & 1.74 & 0.11 & 2.2 \\
APT402 & 0.16 & 1.92 & 0.21 & 2.5 \\
\hline
\end{tabular}


table S3. Occlusion data from the control and treatment groups in the 120-min rabbit model of arterial thrombosis.

\begin{tabular}{|c|c|c|}
\hline Animal ID & Group & Occlusion Time (sec) \\
\hline 6481 & Control & 15 \\
\hline 6484 & Control & 60 \\
\hline 6485 & Control & 17 \\
\hline 5505 & Control & 81 \\
\hline 5506 & Control & 14 \\
\hline 5507 & Control & 44 \\
\hline 6729 & Control & none \\
\hline 6730 & Control & none \\
\hline 6791 & Control & none \\
\hline \multirow[t]{2}{*}{6680} & Control & none \\
\hline & Occluded & $6 / 10$ \\
\hline 218 & HPMC & none \\
\hline 226 & HPMC & none \\
\hline 6787 & HPMC & 27 \\
\hline 6702 & HPMC & 120 \\
\hline 6681 & HPMC & none \\
\hline \multirow[t]{2}{*}{6676} & HPMC & 89 \\
\hline & Occluded & $3 / 6$ \\
\hline 5508 & Clopidogrel & 109 \\
\hline 5651 & Clopidogrel & 74 \\
\hline 5654 & Clopidogrel & 41 \\
\hline 5616 & Clopidogrel & none \\
\hline 171 & Clopidogrel & 50 \\
\hline \multirow[t]{2}{*}{173} & Clopidogrel & none \\
\hline & Occluded & $4 / 6$ \\
\hline 5460 & Enoxaparin & none \\
\hline 5461 & Enoxaparin & none \\
\hline 6937 & Enoxaparin & none \\
\hline 6936 & Enoxaparin & 14 \\
\hline 166 & Enoxaparin & 105 \\
\hline
\end{tabular}




\begin{tabular}{|c|c|c|}
\hline 172 & Enoxaparin & none \\
\hline & Occluded & $2 / 6$ \\
\hline 5737 & Bivalirudin & none \\
\hline 5738 & Bivalirudin & 59 \\
\hline 6217 & Bivalirudin & none \\
\hline 164 & Bivalirudin & none \\
\hline 165 & Bivalirudin & none \\
\hline 167 & Bivalirudin & none \\
\hline \multirow[t]{2}{*}{170} & Bivalirudin & none \\
\hline & Occluded & $1 / 7$ \\
\hline 205 & Ticagrelor & none \\
\hline 206 & Ticagrelor & none \\
\hline 208 & Ticagrelor & none \\
\hline 215 & Ticagrelor & none \\
\hline 217 & Ticagrelor & none \\
\hline \multirow[t]{2}{*}{6788} & Ticagrelor & none \\
\hline & Occluded & $0 / 6$ \\
\hline 207 & Ticagrelor + Bivalirudin & none \\
\hline 209 & Ticagrelor + Bivalirudin & none \\
\hline 216 & Ticagrelor + Bivalirudin & none \\
\hline 219 & Ticagrelor + Bivalirudin & none \\
\hline 6728 & Ticagrelor + Bivalirudin & none \\
\hline \multirow[t]{2}{*}{6796} & Ticagrelor + Bivalirudin & none \\
\hline & Occluded & $0 / 6$ \\
\hline 6034 & APT102 & 26 \\
\hline 6073 & APT102 & 48 \\
\hline 6074 & APT102 & 65 \\
\hline 6075 & APT102 & 15 \\
\hline 191 & APT102 & none \\
\hline \multirow[t]{2}{*}{130} & APT102 & none \\
\hline & Occluded & $4 / 6$ \\
\hline 5736 & APT402 $4 \mu \mathrm{g} / \mathrm{kg} / \mathrm{min}$ & none \\
\hline 5758 & APT402 $4 \mu \mathrm{g} / \mathrm{kg} / \mathrm{min}$ & none \\
\hline
\end{tabular}




\begin{tabular}{|c|c|c|}
\hline 5856 & APT402 $4 \mu \mathrm{g} / \mathrm{kg} / \mathrm{min}$ & none \\
\hline 5857 & APT402 $4 \mu \mathrm{g} / \mathrm{kg} / \mathrm{min}$ & 45 \\
\hline 6215 & APT $4024 \mu \mathrm{g} / \mathrm{kg} / \mathrm{min}$ & none \\
\hline \multirow[t]{2}{*}{123} & APT402 $4 \mu \mathrm{g} / \mathrm{kg} / \mathrm{min}$ & none \\
\hline & Occluded & $1 / 6$ \\
\hline 5621 & APT402 $12 \mu \mathrm{g} / \mathrm{kg} / \mathrm{min}$ & none \\
\hline 5622 & APT402 $12 \mu \mathrm{g} / \mathrm{kg} / \mathrm{min}$ & none \\
\hline 5655 & APT402 $12 \mu \mathrm{g} / \mathrm{kg} / \mathrm{min}$ & none \\
\hline 5650 & APT402 $12 \mu \mathrm{g} / \mathrm{kg} / \mathrm{min}$ & none \\
\hline 5858 & APT402 $12 \mu \mathrm{g} / \mathrm{kg} / \mathrm{min}$ & none \\
\hline \multirow[t]{2}{*}{6216} & APT402 $12 \mu \mathrm{g} / \mathrm{kg} / \mathrm{min}$ & none \\
\hline & Occluded & $0 / 6$ \\
\hline 136 & APT402 $24 \mu \mathrm{g} / \mathrm{kg} / \mathrm{min}$ & none \\
\hline 140 & APT402 $24 \mu \mathrm{g} / \mathrm{kg} / \mathrm{min}$ & none \\
\hline 141 & APT402 $24 \mu \mathrm{g} / \mathrm{kg} / \mathrm{min}$ & none \\
\hline 142 & APT402 $24 \mu \mathrm{g} / \mathrm{kg} / \mathrm{min}$ & none \\
\hline 145 & APT402 $24 \mu \mathrm{g} / \mathrm{kg} / \mathrm{min}$ & none \\
\hline \multirow[t]{2}{*}{165} & APT402 $24 \mu \mathrm{g} / \mathrm{kg} / \mathrm{min}$ & none \\
\hline & Occluded & $0 / 6$ \\
\hline
\end{tabular}


table S4. Thrombus weight data from the control and treatment groups in the 120-min rabbit model of arterial thrombosis.

\begin{tabular}{|c|c|c|}
\hline Animal ID & Group & Thrombus weight (mg) \\
\hline 6481 & Control & 18.5 \\
\hline 6484 & Control & 2.2 \\
\hline 6485 & Control & 11.8 \\
\hline 5505 & Control & 2.5 \\
\hline 5506 & Control & 5.8 \\
\hline 5507 & Control & 1.7 \\
\hline 6729 & Control & 8 \\
\hline 6730 & Control & 1 \\
\hline 6791 & Control & 6.0 \\
\hline \multirow[t]{4}{*}{6680} & Control & 20.0 \\
\hline & MEAN & 7.8 \\
\hline & SD & 6.9 \\
\hline & SEM & 2.2 \\
\hline 218 & HPMC & 7.8 \\
\hline 226 & HPMC & 1.5 \\
\hline 6787 & HPMC & 18.5 \\
\hline 6702 & HPMC & 10 \\
\hline 6681 & HPMC & 1 \\
\hline \multirow[t]{4}{*}{6676} & HPMC & 7 \\
\hline & MEAN & 7.6 \\
\hline & SD & 6.4 \\
\hline & SEM & 2.6 \\
\hline 5508 & Clopidogrel & 3.2 \\
\hline 5654 & Clopidogrel & 3.1 \\
\hline 5651 & Clopidogrel & 2.3 \\
\hline 5616 & Clopidogrel & 1.1 \\
\hline 171 & Clopidogrel & 4.0 \\
\hline \multirow[t]{3}{*}{173} & Clopidogrel & 8.3 \\
\hline & MEAN & 3.7 \\
\hline & SD & 2.5 \\
\hline
\end{tabular}


SEM

\begin{tabular}{|c|c|c|}
\hline 5460 & Enoxaparin & 0.1 \\
\hline 5461 & Enoxaparin & 2 \\
\hline 6936 & Enoxaparin & 5.3 \\
\hline 6937 & Enoxaparin & 0 \\
\hline 166 & Enoxaparin & 14 \\
\hline \multirow[t]{4}{*}{172} & Enoxaparin & 2 \\
\hline & MEAN & 3.9 \\
\hline & SD & 5.3 \\
\hline & SEM & 2.2 \\
\hline 5737 & Bivalirudin & 10 \\
\hline 5738 & Bivalirudin & 3 \\
\hline 6217 & Bivalirudin & 7 \\
\hline 164 & Bivalirudin & 2.5 \\
\hline 165 & Bivalirudin & 12 \\
\hline 167 & Bivalirudin & 0.7 \\
\hline \multirow[t]{4}{*}{170} & Bivalirudin & 0.8 \\
\hline & MEAN & 5.1 \\
\hline & $\mathrm{SD}$ & 4.6 \\
\hline & SEM & 1.7 \\
\hline 205 & Ticagrelor & 7 \\
\hline 206 & Ticagrelor & 2 \\
\hline 208 & Ticagrelor & 1.6 \\
\hline 215 & Ticagrelor & 0.2 \\
\hline 217 & Ticagrelor & 0.5 \\
\hline \multirow[t]{4}{*}{6788} & Ticagrelor & 3.9 \\
\hline & MEAN & 2.5 \\
\hline & SD & 2.6 \\
\hline & SEM & 1.0 \\
\hline 207 & Ticagrelor + Bivalirudin & 1.4 \\
\hline 209 & Ticagrelor + Bivalirudin & 3.4 \\
\hline
\end{tabular}




\begin{tabular}{|c|c|c|}
\hline 219 & Ticagrelor + Bivalirudin & 2.8 \\
\hline 216 & Ticagrelor + Bivalirudin & 1 \\
\hline 6728 & Ticagrelor + Bivalirudin & 1 \\
\hline \multirow[t]{4}{*}{6796} & Ticagrelor + Bivalirudin & 0 \\
\hline & MEAN & 1.6 \\
\hline & $\mathrm{SD}$ & 1.3 \\
\hline & SEM & 0.5 \\
\hline 6034 & APT102 & 2.5 \\
\hline 6073 & APT102 & 1.1 \\
\hline 6074 & APT102 & 2.2 \\
\hline 6075 & APT102 & 4.8 \\
\hline 130 & APT102 & 4.1 \\
\hline \multirow[t]{4}{*}{191} & APT102 & 1.7 \\
\hline & MEAN & 2.7 \\
\hline & $\mathrm{SD}$ & 1.4 \\
\hline & SEM & 0.6 \\
\hline 5736 & APT402 $4 \mu \mathrm{g} / \mathrm{kg} / \mathrm{min}$ & 5 \\
\hline 5758 & APT402 $4 \mu \mathrm{g} / \mathrm{kg} / \mathrm{min}$ & 4 \\
\hline 5856 & APT402 $4 \mu \mathrm{g} / \mathrm{kg} / \mathrm{min}$ & 0 \\
\hline 5857 & APT402 $4 \mu \mathrm{g} / \mathrm{kg} / \mathrm{min}$ & 5.2 \\
\hline 6215 & APT402 $4 \mu \mathrm{g} / \mathrm{kg} / \mathrm{min}$ & 3 \\
\hline \multirow[t]{4}{*}{123} & APT402 $4 \mu \mathrm{g} / \mathrm{kg} / \mathrm{min}$ & 0.7 \\
\hline & MEAN & 3.0 \\
\hline & $\mathrm{SD}$ & 2.2 \\
\hline & SEM & 0.9 \\
\hline 5650 & APT402 $12 \mu \mathrm{g} / \mathrm{kg} / \mathrm{min}$ & 2.4 \\
\hline 5655 & APT402 $12 \mu \mathrm{g} / \mathrm{kg} / \mathrm{min}$ & 3.1 \\
\hline 5621 & APT402 $12 \mu \mathrm{g} / \mathrm{kg} / \mathrm{min}$ & 0.9 \\
\hline 5622 & APT402 $12 \mu \mathrm{g} / \mathrm{kg} / \mathrm{min}$ & 0 \\
\hline 5858 & APT402 $12 \mu \mathrm{g} / \mathrm{kg} / \mathrm{min}$ & 0 \\
\hline \multirow[t]{3}{*}{6216} & APT402 $12 \mu \mathrm{g} / \mathrm{kg} / \mathrm{min}$ & 1.3 \\
\hline & MEAN & 1.3 \\
\hline & SD & 1.3 \\
\hline
\end{tabular}


Submitted Manuscript: Confidential

\begin{tabular}{ccc} 
& SEM & 0.5 \\
\hline 136 & APT402 $24 \mu \mathrm{g} / \mathrm{kg} / \mathrm{min}$ & 0.7 \\
140 & APT402 $24 \mu \mathrm{g} / \mathrm{kg} / \mathrm{min}$ & 0.6 \\
141 & APT402 $24 \mu \mathrm{g} / \mathrm{kg} / \mathrm{min}$ & 0.18 \\
142 & APT402 $24 \mu \mathrm{g} / \mathrm{kg} / \mathrm{min}$ & 0.43 \\
145 & APT402 $24 \mu \mathrm{g} / \mathrm{kg} / \mathrm{min}$ & 0.19 \\
163 & APT402 $24 \mu \mathrm{g} / \mathrm{kg} / \mathrm{min}$ & 0 \\
\hline & MEAN & 0.4 \\
& SD & 0.3 \\
& SEM & 0.1 \\
\hline
\end{tabular}


Submitted Manuscript: Confidential

table S5. Bleeding time (sec) from the control and treatment groups in the 120-min rabbit model of arterial thrombosis.

\begin{tabular}{|c|c|c|c|c|c|}
\hline Animal ID & Group & BSLN & $30 \mathrm{~min}$ & $60 \mathrm{~min}$ & $120 \mathrm{~min}$ \\
\hline 6481 & Control & 94.0 & 107.0 & 126.0 & 93.0 \\
\hline 6484 & Control & 106.0 & 91.0 & 87.0 & 91.0 \\
\hline 6485 & Control & 91.0 & 76.0 & 83.0 & 105.0 \\
\hline 5505 & Control & 94.0 & 89.0 & 95.0 & 100.0 \\
\hline 5506 & Control & 111.0 & 113.0 & 118.0 & 115.0 \\
\hline 5507 & Control & 118.0 & 103.0 & 105.0 & 99.0 \\
\hline 6729 & Control & 174.0 & 158.0 & 194.0 & 153.0 \\
\hline 6730 & Control & 119.0 & 114.0 & 107.3 & 102.0 \\
\hline 6791 & Control & 142.5 & 104.5 & 94.0 & 106.5 \\
\hline \multirow[t]{4}{*}{6680} & Control & 191.0 & 143.5 & 141.5 & 124.0 \\
\hline & MEAN & 124.1 & 96.5 & 102.3 & 100.5 \\
\hline & SD & 34.6 & 13.6 & 17.2 & 8.7 \\
\hline & SEM & 10.9 & 4.3 & 5.4 & 2.8 \\
\hline 218 & HPMC & 174.0 & 121.5 & 112.0 & 103.0 \\
\hline 226 & HPMC & 177.0 & 210.5 & 179.5 & 192.0 \\
\hline 6787 & HPMC & 153.5 & 243.0 & 164.0 & 119.0 \\
\hline 6702 & HPMC & 158.7 & 181.0 & 165.0 & 139.0 \\
\hline 6681 & HPMC & 191.0 & 150.0 & 242.5 & 170.0 \\
\hline \multirow[t]{4}{*}{6676} & HPMC & 110.0 & 128.0 & 118.0 & 125.0 \\
\hline & MEAN & 160.7 & 172.3 & 163.5 & 141.3 \\
\hline & SD & 28.2 & 48.1 & 47.4 & 33.6 \\
\hline & SEM & 11.5 & 19.6 & 19.3 & 13.7 \\
\hline 5508 & Clopidogrel & 116.0 & 139.0 & 196.0 & 175.0 \\
\hline 5651 & Clopidogrel & 106.0 & 114.0 & 190.0 & 177.0 \\
\hline 5654 & Clopidogrel & 153.0 & 145.0 & 201.0 & 255.0 \\
\hline 5616 & Clopidogrel & 131.0 & 134.0 & 140.0 & 154.0 \\
\hline 171 & Clopidogrel & 142.0 & 270.0 & 219.0 & 300.0 \\
\hline \multirow[t]{4}{*}{173} & Clopidogrel & 93.0 & 137.0 & 165.0 & 107.0 \\
\hline & MEAN & 123.5 & 156.5 & 185.2 & 194.7 \\
\hline & SD & 22.6 & 56.6 & 28.2 & 70.4 \\
\hline & SEM & 9.2 & 23.1 & 11.5 & 28.7 \\
\hline 5460 & Enoxaparin & 114.0 & 149.0 & 146.0 & 110.0 \\
\hline 5461 & Enoxaparin & 137.0 & 144.0 & 222.0 & 218.0 \\
\hline 6937 & Enoxaparin & 152.0 & 191.0 & 172.0 & 152.0 \\
\hline 6936 & Enoxaparin & 161.0 & 138.0 & 255.0 & 291.0 \\
\hline 166 & Enoxaparin & 170.0 & 224.0 & 138.0 & 157.0 \\
\hline 172 & Enoxaparin & 105.5 & 136.5 & 130.5 & 173.0 \\
\hline
\end{tabular}


Submitted Manuscript: Confidential

\begin{tabular}{|c|c|c|c|c|c|}
\hline & MEAN & 139.9 & 163.8 & 177.3 & 183.5 \\
\hline & SD & 25.9 & 35.7 & 50.6 & 63.2 \\
\hline & SEM & 10.6 & 14.6 & 20.6 & 25.8 \\
\hline 5737 & Bivalirudin & 133.0 & 264.5 & 206.0 & 300 \\
\hline 5738 & Bivalirudin & 128.5 & 262.0 & 300 & 300 \\
\hline 6217 & Bivalirudin & 123.0 & 195.0 & 205.0 & 260.0 \\
\hline 164 & Bivalirudin & 164.0 & 273.0 & 300 & 221.0 \\
\hline 165 & Bivalirudin & 88.0 & 244.0 & 263.0 & 187.0 \\
\hline 167 & Bivalirudin & 130.0 & 300 & 300 & 300 \\
\hline \multirow[t]{4}{*}{170} & Bivalirudin & 137.5 & 300 & 281.0 & 300 \\
\hline & MEAN & 129.1 & 262.6 & 265.0 & 266.9 \\
\hline & SD & 22.5 & 36.1 & 42.8 & 46.4 \\
\hline & SEM & 8.5 & 13.6 & 16.2 & 17.5 \\
\hline 205 & Ticagrelor & 143.0 & 193.0 & 219.0 & 292.0 \\
\hline 206 & Ticagrelor & 160.0 & 172.0 & 158.0 & 216.0 \\
\hline 208 & Ticagrelor & 107.0 & 118.0 & 106.0 & 138.0 \\
\hline 215 & Ticagrelor & 163.0 & 279.0 & 265.0 & 287.0 \\
\hline 217 & Ticagrelor & 170.0 & 141.5 & 236.0 & 219.0 \\
\hline \multirow[t]{4}{*}{6788} & Ticagrelor & 105.5 & 121.0 & 123.5 & 106.5 \\
\hline & MEAN & 141.4 & 170.8 & 184.6 & 209.8 \\
\hline & SD & 28.7 & 60.5 & 64.7 & 75.7 \\
\hline & SEM & 11.7 & 24.7 & 26.4 & 30.9 \\
\hline 207 & Ticagrelor + Bivalirudin & 147.0 & 239.0 & 300 & 300 \\
\hline 209 & Ticagrelor + Bivalirudin & 170.0 & 300 & 300 & 300 \\
\hline 216 & Ticagrelor + Bivalirudin & 163 & 300 & 300 & 300 \\
\hline 219 & Ticagrelor + Bivalirudin & 182.0 & 300 & 300 & 300 \\
\hline 6728 & Ticagrelor + Bivalirudin & 114.0 & 300 & 300 & 300 \\
\hline \multirow[t]{4}{*}{6796} & Ticagrelor + Bivalirudin & 126.5 & 300 & 300 & 300 \\
\hline & MEAN & 150.4 & 289.8 & 300 & 300 \\
\hline & SD & 26.3 & 24.9 & 0.0 & 0.0 \\
\hline & SEM & 10.7 & 10.2 & 0.0 & 0.0 \\
\hline 6034 & APT102 & 80.0 & 80.0 & 73.0 & 72.0 \\
\hline 6073 & APT102 & 84.0 & 121.0 & 123.0 & 147.0 \\
\hline 6074 & APT102 & 115.0 & 120.0 & 124.0 & 117.0 \\
\hline 6075 & APT102 & 105.0 & 116.0 & 121.0 & 139.0 \\
\hline 130 & APT102 & 138.0 & 107.0 & 103.0 & 105.0 \\
\hline \multirow[t]{3}{*}{191} & APT102 & 60.0 & 67.0 & 57.0 & 58.0 \\
\hline & MEAN & 97.0 & 101.8 & 100.2 & 106.3 \\
\hline & $\mathrm{SD}$ & 27.9 & 22.9 & 28.8 & 35.6 \\
\hline
\end{tabular}


Submitted Manuscript: Confidential

\begin{tabular}{|c|c|c|c|c|c|}
\hline & SEM & 11.4 & 9.3 & 11.7 & 14.6 \\
\hline 5736 & APT402 $4 \mu \mathrm{g} / \mathrm{kg} / \mathrm{min}$ & 133.5 & 132.5 & 117.0 & 111.5 \\
\hline 5758 & APT402 $4 \mu \mathrm{g} / \mathrm{kg} / \mathrm{min}$ & 116.0 & 102.5 & 156.0 & 177.5 \\
\hline 5856 & APT402 $4 \mu \mathrm{g} / \mathrm{kg} / \mathrm{min}$ & 75.0 & 109.0 & 104.5 & 92.0 \\
\hline 5857 & APT402 $4 \mu \mathrm{g} / \mathrm{kg} / \mathrm{min}$ & 119.5 & 111.5 & 112.0 & 109.5 \\
\hline 6215 & APT402 $4 \mu \mathrm{g} / \mathrm{kg} / \mathrm{min}$ & 92.0 & 118.0 & 135.0 & 135.0 \\
\hline \multirow[t]{4}{*}{123} & APT402 $4 \mu \mathrm{g} / \mathrm{kg} / \mathrm{min}$ & 171.0 & 183.0 & 208.0 & 177.0 \\
\hline & MEAN & 117.8 & 126.1 & 138.8 & 133.8 \\
\hline & SD & 33.4 & 29.7 & 38.6 & 36.4 \\
\hline & SEM & 13.6 & 12.1 & 15.8 & 14.8 \\
\hline 5621 & APT402 $12 \mu \mathrm{g} / \mathrm{kg} / \mathrm{min}$ & 130.0 & 111.0 & 111.0 & 102.0 \\
\hline 5622 & APT402 $12 \mu \mathrm{g} / \mathrm{kg} / \mathrm{min}$ & 142.0 & 130.0 & 115.0 & 134.0 \\
\hline 5655 & APT402 $12 \mu \mathrm{g} / \mathrm{kg} / \mathrm{min}$ & 106 & 116.0 & 126.0 & 125.0 \\
\hline 5650 & APT402 $12 \mu \mathrm{g} / \mathrm{kg} / \mathrm{min}$ & 115.0 & 112.0 & 111.0 & 105.0 \\
\hline 5858 & APT402 $12 \mu \mathrm{g} / \mathrm{kg} / \mathrm{min}$ & 94.0 & 104.0 & 99.5 & 98.0 \\
\hline \multirow[t]{4}{*}{6216} & APT402 $12 \mu \mathrm{g} / \mathrm{kg} / \mathrm{min}$ & 93.0 & 129.0 & 108.0 & 119.0 \\
\hline & MEAN & 113.3 & 117.0 & 111.8 & 113.8 \\
\hline & $\mathrm{SD}$ & 19.7 & 10.4 & 8.7 & 14.3 \\
\hline & SEM & 8.0 & 4.3 & 3.6 & 5.9 \\
\hline 136 & APT402 $24 \mu \mathrm{g} / \mathrm{kg} / \mathrm{min}$ & 153.5 & 158.0 & 127.5 & 144.0 \\
\hline 140 & APT402 $24 \mu \mathrm{g} / \mathrm{kg} / \mathrm{min}$ & 188.0 & 154.0 & 98.5 & 85.0 \\
\hline 141 & APT402 $24 \mu \mathrm{g} / \mathrm{kg} / \mathrm{min}$ & 143.0 & 117.5 & 109.0 & 126.5 \\
\hline 142 & APT402 $24 \mu \mathrm{g} / \mathrm{kg} / \mathrm{min}$ & 147.0 & 218.0 & 104.0 & 213.0 \\
\hline 145 & APT402 $24 \mu \mathrm{g} / \mathrm{kg} / \mathrm{min}$ & 178.0 & 120.0 & 152.0 & 130.0 \\
\hline \multirow[t]{4}{*}{163} & APT402 $24 \mu \mathrm{g} / \mathrm{kg} / \mathrm{min}$ & 126.0 & 109.0 & 76.0 & 96.0 \\
\hline & MEAN & 155.9 & 146.1 & 111.2 & 132.4 \\
\hline & $\mathrm{SD}$ & 23.1 & 40.6 & 26.0 & 45.3 \\
\hline & SEM & 9.4 & 16.6 & 10.6 & 18.5 \\
\hline
\end{tabular}


table S6. Prothrombin time (sec) from the control and treatment groups in the 120-min rabbit model of arterial thrombosis.

\begin{tabular}{|c|c|c|c|c|c|}
\hline Animal ID & Group & BSLN & $30 \mathrm{~min}$ & $60 \mathrm{~min}$ & $120 \mathrm{~min}$ \\
\hline 6481 & Control & 6.8 & 6.9 & 6.8 & 6.7 \\
\hline 6484 & Control & 6.5 & 6.6 & 6.8 & 6.7 \\
\hline 6485 & Control & 6.7 & 6.9 & 7.3 & 7.2 \\
\hline 5505 & Control & 6.9 & 7.1 & 6.9 & 6.8 \\
\hline 5507 & Control & 6.8 & 7.0 & 7.1 & 7.0 \\
\hline 5506 & Control & 6.9 & 6.9 & 6.9 & 7.0 \\
\hline 6729 & Control & 5.9 & 7.2 & 8.8 & 6.5 \\
\hline 6730 & Control & 9.7 & 8.1 & 12.6 & 12.7 \\
\hline 6791 & Control & 7.6 & 6.7 & 7.5 & 7.9 \\
\hline \multirow[t]{4}{*}{6680} & Control & 7.3 & NA & 7.9 & 8.6 \\
\hline & MEAN & 7.1 & 7.0 & 7.9 & 7.7 \\
\hline & SD & 1.0 & 0.4 & 1.8 & 1.9 \\
\hline & SEM & 0.3 & 0.1 & 0.6 & 0.6 \\
\hline 218 & HPMC & 8.7 & 8.4 & 8 & 7.7 \\
\hline 226 & HPMC & 7.5 & 8 & 8.2 & 8.0 \\
\hline 6787 & HPMC & 10.8 & 11.1 & 10.8 & 10.9 \\
\hline 6702 & HPMC & 8.3 & 7.7 & 6.5 & 6.3 \\
\hline \multirow[t]{4}{*}{6681} & HPMC & 9.1 & 8 & 6.8 & 6.7 \\
\hline & MEAN & 8.9 & 8.6 & 8.1 & 7.9 \\
\hline & SD & 1.2 & 1.4 & 1.7 & 1.8 \\
\hline & SEM & 0.5 & 0.6 & 0.8 & 0.8 \\
\hline 5508 & Clopidogrel & 6.6 & 6.5 & 6.9 & 6.8 \\
\hline 5651 & Clopidogrel & 6.7 & 7.0 & 8.2 & 7.6 \\
\hline 5654 & Clopidogrel & 7.0 & 7.4 & 7.1 & 7.1 \\
\hline 5616 & Clopidogrel & 7.1 & 7.1 & 7.0 & 7.3 \\
\hline 171 & Clopidogrel & 8.8 & 9.1 & 9.7 & 9.2 \\
\hline \multirow[t]{4}{*}{173} & Clopidogrel & 8.9 & 8.8 & 8.6 & 8.6 \\
\hline & MEAN & 7.5 & 7.6 & 7.9 & 7.8 \\
\hline & SD & 1.1 & 1.1 & 1.1 & 0.9 \\
\hline & SEM & 0.4 & 0.4 & 0.5 & 0.4 \\
\hline 5460 & Enoxaparin & 6.8 & 7.0 & 7.0 & 7.0 \\
\hline 5461 & Enoxaparin & 6.5 & 6.6 & 6.8 & 6.7 \\
\hline 6937 & Enoxaparin & 7.4 & 7.2 & 6.9 & 7.1 \\
\hline
\end{tabular}


Submitted Manuscript: Confidential

\begin{tabular}{|c|c|c|c|c|c|}
\hline 6936 & Enoxaparin & 6.6 & 6.7 & 6.8 & 6.9 \\
\hline 166 & Enoxaparin & 8.8 & 8.7 & 8.8 & 8.8 \\
\hline \multirow[t]{4}{*}{172} & Enoxaparin & 10.9 & 9.5 & 9.1 & 8.9 \\
\hline & MEAN & 7.8 & 7.6 & 7.6 & 7.6 \\
\hline & SD & 1.7 & 1.2 & 1.1 & 1.0 \\
\hline & SEM & 0.7 & 0.5 & 0.4 & 0.4 \\
\hline 5737 & Bivalirudin & 6.7 & 13.1 & 11.4 & 11.4 \\
\hline 5738 & Bivalirudin & 6.4 & 15.2 & 16.9 & 16.0 \\
\hline 164 & Bivalirudin & 9.8 & 28.3 & 29.4 & 21.9 \\
\hline 165 & Bivalirudin & 8.5 & 23.7 & 26.3 & 25.8 \\
\hline 167 & Bivalirudin & 9.8 & 36.1 & 38.2 & 17.4 \\
\hline \multirow[t]{4}{*}{170} & Bivalirudin & 10.5 & 28.8 & 28.8 & 28.3 \\
\hline & MEAN & 8.6 & 24.2 & 25.2 & 20.1 \\
\hline & SD & 1.8 & 8.8 & 9.6 & 6.4 \\
\hline & SEM & 0.7 & 3.6 & 3.9 & 2.6 \\
\hline 205 & Ticagrelor & 9.4 & 9.2 & 9.2 & 8.9 \\
\hline 206 & Ticagrelor & 8.2 & 10.7 & 8.2 & 8.4 \\
\hline 208 & Ticagrelor & 9.1 & 9.2 & 8.8 & 8.5 \\
\hline 215 & Ticagrelor & 8.6 & 10 & 8.2 & 8.3 \\
\hline 217 & Ticagrelor & 7.6 & 7.7 & 8 & 8.6 \\
\hline \multirow[t]{4}{*}{6788} & Ticagrelor & 11 & 11.1 & 10.7 & 8.9 \\
\hline & MEAN & 9.0 & 9.7 & 8.9 & 8.6 \\
\hline & $\mathrm{SD}$ & 1.2 & 1.2 & 1.0 & 0.3 \\
\hline & SEM & 0.5 & 0.5 & 0.4 & 0.1 \\
\hline 207 & Ticagrelor + Bivalirudin & 8.2 & 23.5 & 29.0 & 35.1 \\
\hline 209 & Ticagrelor + Bivalirudin & 8.5 & 29.4 & 30.4 & 37.9 \\
\hline 216 & Ticagrelor + Bivalirudin & 6.9 & 20.9 & 11.5 & 24.8 \\
\hline 219 & Ticagrelor + Bivalirudin & 8.4 & 18.8 & 20.9 & 18.2 \\
\hline 6728 & Ticagrelor + Bivalirudin & 8.6 & 30.8 & 30.7 & 32 \\
\hline \multirow[t]{4}{*}{6796} & Ticagrelor + Bivalirudin & 10.4 & 29.4 & 27.6 & 27.3 \\
\hline & MEAN & 8.5 & 25.5 & 25.0 & 29.2 \\
\hline & $\mathrm{SD}$ & 1.1 & 5.1 & 7.5 & 7.2 \\
\hline & SEM & 0.5 & 2.1 & 3.1 & 3.0 \\
\hline 6034 & APT102 & 7.1 & 7.2 & 7.3 & 7.3 \\
\hline 6073 & APT102 & 6.9 & 6.7 & 7.0 & 6.9 \\
\hline 6074 & APT102 & 6.5 & 6.8 & 6.5 & 6.9 \\
\hline
\end{tabular}


Submitted Manuscript: Confidential

\begin{tabular}{|c|c|c|c|c|c|}
\hline 6075 & APT102 & 6.6 & 6.6 & 6.8 & 6.8 \\
\hline 191 & APT102 & 10.7 & 10.8 & 10.9 & 10.8 \\
\hline \multirow[t]{4}{*}{130} & APT102 & 12.2 & 13.7 & 13.1 & 11.8 \\
\hline & MEAN & 8.3 & 8.6 & 8.6 & 8.4 \\
\hline & SD & 2.5 & 3.0 & 2.7 & 2.3 \\
\hline & SEM & 1.0 & 1.2 & 1.1 & 0.9 \\
\hline 5736 & APT402 $4 \mu \mathrm{g} / \mathrm{kg} / \mathrm{min}$ & 6.7 & 6.7 & 7.0 & 6.8 \\
\hline 5758 & APT402 $4 \mu \mathrm{g} / \mathrm{kg} / \mathrm{min}$ & 6.3 & 6.4 & 6.6 & 6.5 \\
\hline 5856 & APT402 $4 \mu \mathrm{g} / \mathrm{kg} / \mathrm{min}$ & 6.6 & 6.7 & 6.8 & 6.7 \\
\hline 5857 & APT402 $4 \mu \mathrm{g} / \mathrm{kg} / \mathrm{min}$ & 8.5 & 8.6 & 8.6 & 8.5 \\
\hline 6215 & APT402 $4 \mu \mathrm{g} / \mathrm{kg} / \mathrm{min}$ & 8.5 & NA & NA & NA \\
\hline \multirow[t]{4}{*}{123} & APT402 $4 \mu \mathrm{g} / \mathrm{kg} / \mathrm{min}$ & 8.7 & 8.9 & NA & 9.2 \\
\hline & MEAN & 7.6 & 7.4 & 7.2 & 7.5 \\
\hline & SD & 1.1 & 1.2 & 0.9 & 1.3 \\
\hline & SEM & 0.5 & 0.5 & 0.5 & 0.6 \\
\hline 5621 & APT402 $12 \mu \mathrm{g} / \mathrm{kg} / \mathrm{min}$ & 6.6 & 6.6 & 6.8 & 6.7 \\
\hline 5622 & APT402 $12 \mu \mathrm{g} / \mathrm{kg} / \mathrm{min}$ & 6.7 & 7.0 & 7.0 & 6.9 \\
\hline 5655 & APT402 $12 \mu \mathrm{g} / \mathrm{kg} / \mathrm{min}$ & 6.7 & 6.8 & 6.9 & 7.0 \\
\hline 5650 & APT402 $12 \mu \mathrm{g} / \mathrm{kg} / \mathrm{min}$ & 6.6 & 6.7 & 6.8 & 6.9 \\
\hline 5858 & APT402 $12 \mu \mathrm{g} / \mathrm{kg} / \mathrm{min}$ & 6.9 & 6.9 & 6.8 & 6.9 \\
\hline \multirow[t]{4}{*}{6216} & APT402 $12 \mu \mathrm{g} / \mathrm{kg} / \mathrm{min}$ & 8.6 & 8.6 & 8.8 & 8.6 \\
\hline & MEAN & 7.0 & 7.1 & 7.2 & 7.2 \\
\hline & SD & 0.8 & 0.7 & 0.8 & 0.7 \\
\hline & SEM & 0.3 & 0.3 & 0.3 & 0.3 \\
\hline 136 & APT402 $24 \mu \mathrm{g} / \mathrm{kg} / \mathrm{min}$ & 7.8 & 8.6 & 9.0 & 8.3 \\
\hline 140 & APT402 $24 \mu \mathrm{g} / \mathrm{kg} / \mathrm{min}$ & 7.7 & 7.9 & 9.1 & 8.1 \\
\hline 141 & APT402 $24 \mu \mathrm{g} / \mathrm{kg} / \mathrm{min}$ & 8.9 & 8.2 & 8.7 & 7.4 \\
\hline 142 & APT402 $24 \mu \mathrm{g} / \mathrm{kg} / \mathrm{min}$ & 9 & 8.6 & 9.6 & 9.2 \\
\hline 145 & APT402 $24 \mu \mathrm{g} / \mathrm{kg} / \mathrm{min}$ & 7 & 9.2 & 9.7 & 9.8 \\
\hline \multirow[t]{4}{*}{163} & APT402 $24 \mu \mathrm{g} / \mathrm{kg} / \mathrm{min}$ & 10.8 & 11.1 & 10.8 & 10.9 \\
\hline & MEAN & 8.5 & 8.9 & 9.5 & 9.0 \\
\hline & SD & 1.3 & 1.1 & 0.7 & 1.3 \\
\hline & SEM & 0.5 & 0.5 & 0.3 & 0.5 \\
\hline
\end{tabular}


Submitted Manuscript: Confidential

table S7. Activated partial thromboplastin time (sec) from the control and treatment groups in the 120-min rabbit model of arterial thrombosis.

\begin{tabular}{|c|c|c|c|c|c|}
\hline Animal ID & Group & BSLN & $30 \mathrm{~min}$ & $60 \mathrm{~min}$ & $120 \mathrm{~min}$ \\
\hline 6481 & Control & 141.6 & 73.3 & 71.6 & 69.4 \\
\hline 6484 & Control & 102.5 & 90.9 & 61.7 & 69.3 \\
\hline 6485 & Control & 98.1 & 68.5 & 91.2 & 99.0 \\
\hline 5505 & Control & 88.0 & 86.9 & 104.3 & 102.5 \\
\hline 5506 & Control & 76.9 & 75.0 & 70.1 & 73.5 \\
\hline 5507 & Control & 58.3 & 52.7 & 60.4 & 55.6 \\
\hline 6729 & Control & 72.3 & 70.5 & 73 & 66.5 \\
\hline 6730 & Control & 93.5 & 71.8 & 64.5 & 80.5 \\
\hline 6791 & Control & 106.8 & 95.5 & 109.3 & 85.3 \\
\hline \multirow[t]{4}{*}{6680} & Control & 61.5 & 78.5 & 53 & 55 \\
\hline & MEAN & 90.0 & 76.4 & 75.9 & 75.7 \\
\hline & SD & 24.7 & 12.4 & 19.2 & 16.3 \\
\hline & SEM & 7.8 & 3.9 & 6.1 & 5.1 \\
\hline 218 & HPMC & 70.0 & 54.5 & 54.5 & 62.5 \\
\hline 226 & HPMC & 85.5 & 70.0 & 88.5 & 76.5 \\
\hline 6787 & HPMC & 83.5 & 84 & 81 & 87.5 \\
\hline 6702 & HPMC & 68.3 & 65.5 & 58.3 & 76.5 \\
\hline \multirow[t]{4}{*}{6681} & HPMC & 48.3 & 48.5 & 48.3 & 44.5 \\
\hline & MEAN & 71.1 & 64.5 & 66.1 & 69.5 \\
\hline & SD & 14.9 & 13.9 & 17.6 & 16.6 \\
\hline & SEM & 6.7 & 6.2 & 7.9 & 7.4 \\
\hline 5508 & Clopidogrel & 87.3 & 90.3 & 41.5 & 85.3 \\
\hline 5651 & Clopidogrel & 70.1 & 61.3 & 72.9 & 68.9 \\
\hline 5654 & Clopidogrel & 49.0 & 45.3 & 54.8 & 54.9 \\
\hline 5616 & Clopidogrel & 90.1 & 84.6 & 80.3 & 80.7 \\
\hline 171 & Clopidogrel & 80.0 & 95.0 & 74.0 & 69.0 \\
\hline \multirow[t]{4}{*}{173} & Clopidogrel & 54.0 & 58.5 & 68.0 & 66.5 \\
\hline & MEAN & 71.8 & 72.5 & 65.2 & 70.9 \\
\hline & SD & 17.2 & 20.1 & 14.4 & 10.8 \\
\hline & SEM & 7.0 & 8.2 & 5.9 & 4.4 \\
\hline 5460 & Enoxaparin & 69.6 & 152.7 & 75.9 & 138.1 \\
\hline 5461 & Enoxaparin & 96.7 & 300 & 171 & 149.4 \\
\hline 6937 & Enoxaparin & 88.5 & 162.9 & 122 & 100.4 \\
\hline 6936 & Enoxaparin & 142.8 & 300.0 & 171.4 & 154.3 \\
\hline 166 & Enoxaparin & 75.0 & 133.5 & 128.5 & 131.0 \\
\hline \multirow[t]{2}{*}{172} & Enoxaparin & 70.0 & 118.0 & 118.5 & 107.5 \\
\hline & MEAN & 90.4 & 194.5 & 131.2 & 130.1 \\
\hline
\end{tabular}


Submitted Manuscript: Confidential

\begin{tabular}{|c|c|c|c|c|c|}
\hline & SD & 27.8 & 83.2 & 36.1 & 22.0 \\
\hline & SEM & 11.4 & 34.0 & 14.7 & 9.0 \\
\hline 5737 & Bivalirudin & 82.3 & 111.7 & 107.7 & 83.2 \\
\hline 5738 & Bivalirudin & 66.5 & 93.9 & 96.7 & 110.05 \\
\hline 164 & Bivalirudin & 89 & 183 & 241 & 206 \\
\hline 165 & Bivalirudin & 81 & 152 & 190 & 221 \\
\hline 167 & Bivalirudin & 71 & 233.5 & 249 & 119.5 \\
\hline \multirow[t]{4}{*}{170} & Bivalirudin & 70.5 & 124.5 & 190.5 & 195 \\
\hline & MEAN & 76.7 & 149.8 & 179.2 & 155.8 \\
\hline & SD & 8.7 & 51.6 & 64.6 & 58.3 \\
\hline & SEM & 3.5 & 21.1 & 26.4 & 23.8 \\
\hline 205 & Ticagrelor & 65.5 & 63.5 & 85.5 & 105.5 \\
\hline 206 & Ticagrelor & 99 & 65 & 85.5 & 79 \\
\hline 208 & Ticagrelor & 79.5 & 76 & 139 & 114 \\
\hline 215 & Ticagrelor & 74.5 & 74.5 & 109.5 & 76.5 \\
\hline 217 & Ticagrelor & 58 & 49.5 & 62 & 57.5 \\
\hline \multirow[t]{4}{*}{6788} & Ticagrelor & 67.5 & 81.5 & 74 & 74.5 \\
\hline & MEAN & 74.0 & 68.3 & 92.6 & 84.5 \\
\hline & SD & 14.3 & 11.5 & 27.6 & 21.1 \\
\hline & SEM & 5.8 & 4.7 & 11.3 & 8.6 \\
\hline 207 & Ticagrelor + Bivalirudin & 79 & 216 & 254 & 271 \\
\hline 209 & Ticagrelor + Bivalirudin & 94 & 210 & 185 & 229 \\
\hline 216 & Ticagrelor + Bivalirudin & 62.5 & 182.5 & 130 & 174.5 \\
\hline 219 & Ticagrelor + Bivalirudin & 89 & 239 & 179 & 218 \\
\hline 6728 & Ticagrelor + Bivalirudin & 76.5 & 207.5 & 151 & 268.5 \\
\hline \multirow[t]{4}{*}{6796} & Ticagrelor + Bivalirudin & 124.5 & 227 & 273.5 & 292 \\
\hline & MEAN & 87.6 & 213.7 & 195.4 & 242.2 \\
\hline & SD & 21.1 & 19.2 & 56.8 & 43.2 \\
\hline & SEM & 8.6 & 7.8 & 23.2 & 17.6 \\
\hline 6034 & APT102 & 52.7 & 66.0 & 71.1 & 68.4 \\
\hline 6073 & APT102 & 70.7 & 93.6 & 80.5 & 98.7 \\
\hline 6074 & APT102 & 79.0 & 79.9 & 80.2 & 82.0 \\
\hline 6075 & APT102 & 105.2 & 89.7 & 106.7 & 132.7 \\
\hline 191 & APT102 & 51.0 & 48.5 & 58.0 & 56.0 \\
\hline \multirow[t]{4}{*}{130} & APT102 & 69.0 & 72.5 & 78.5 & 48.0 \\
\hline & MEAN & 71.3 & 75.0 & 79.2 & 81.0 \\
\hline & $\mathrm{SD}$ & 19.9 & 16.6 & 16.0 & 31.2 \\
\hline & SEM & 8.1 & 6.8 & 6.5 & 12.7 \\
\hline 5736 & APT402 $4 \mu \mathrm{g} / \mathrm{kg} / \mathrm{min}$ & 82.85 & 82.4 & 92.5 & 110.1 \\
\hline
\end{tabular}


Submitted Manuscript: Confidential

\begin{tabular}{|c|c|c|c|c|c|}
\hline 5758 & APT402 $4 \mu \mathrm{g} / \mathrm{kg} / \mathrm{min}$ & 79.7 & 69 & 81.7 & 72.9 \\
\hline 5856 & APT402 $4 \mu \mathrm{g} / \mathrm{kg} / \mathrm{min}$ & NA & NA & NA & NA \\
\hline 5857 & APT402 $4 \mu \mathrm{g} / \mathrm{kg} / \mathrm{min}$ & 53.9 & 70 & NA & NA \\
\hline 6215 & APT402 $4 \mu \mathrm{g} / \mathrm{kg} / \mathrm{min}$ & 81.2 & 79.8 & NA & 114.1 \\
\hline \multirow[t]{4}{*}{123} & APT402 $4 \mu \mathrm{g} / \mathrm{kg} / \mathrm{min}$ & 81.9 & 95.2 & 86.8 & 154.1 \\
\hline & MEAN & 75.9 & 79.3 & 87.0 & 112.8 \\
\hline & $\mathrm{SD}$ & 12.4 & 10.7 & 5.4 & 33.2 \\
\hline & SEM & 5.5 & 4.8 & 3.1 & 16.6 \\
\hline 5621 & APT402 $12 \mu \mathrm{g} / \mathrm{kg} / \mathrm{min}$ & 77.8 & 73.1 & 65.7 & 66.6 \\
\hline 5622 & APT402 $12 \mu \mathrm{g} / \mathrm{kg} / \mathrm{min}$ & 66.6 & 61.0 & 81.8 & 82.4 \\
\hline 5655 & APT402 $12 \mu \mathrm{g} / \mathrm{kg} / \mathrm{min}$ & 43.6 & 43.6 & 46.9 & 48.1 \\
\hline 5650 & APT402 $12 \mu \mathrm{g} / \mathrm{kg} / \mathrm{min}$ & 93.1 & 97.9 & 103.2 & 119.7 \\
\hline 5858 & APT402 $12 \mu \mathrm{g} / \mathrm{kg} / \mathrm{min}$ & 97.9 & 113.3 & 101.9 & 88.6 \\
\hline \multirow[t]{4}{*}{6216} & APT402 $12 \mu \mathrm{g} / \mathrm{kg} / \mathrm{min}$ & 82.6 & 79.8 & 84.0 & 102.9 \\
\hline & MEAN & 76.9 & 78.1 & 80.6 & 84.7 \\
\hline & SD & 19.7 & 25.0 & 21.6 & 25.5 \\
\hline & SEM & 8.1 & 10.2 & 8.8 & 10.4 \\
\hline 136 & APT402 $24 \mu \mathrm{g} / \mathrm{kg} / \mathrm{min}$ & 71.4 & 72.1 & 81.2 & 71.4 \\
\hline 140 & APT402 $24 \mu \mathrm{g} / \mathrm{kg} / \mathrm{min}$ & 67.2 & 114.1 & 76.3 & 98.7 \\
\hline 141 & APT402 $24 \mu \mathrm{g} / \mathrm{kg} / \mathrm{min}$ & 96.6 & 76.3 & 66.5 & 80.5 \\
\hline 142 & APT402 $24 \mu \mathrm{g} / \mathrm{kg} / \mathrm{min}$ & 110.6 & 98 & 102.2 & 150.5 \\
\hline 145 & APT402 $24 \mu \mathrm{g} / \mathrm{kg} / \mathrm{min}$ & 81.2 & 105 & 101.5 & 118.3 \\
\hline \multirow[t]{4}{*}{163} & APT402 $24 \mu \mathrm{g} / \mathrm{kg} / \mathrm{min}$ & 82 & 93.5 & 92 & 85.5 \\
\hline & MEAN & 84.8 & 93.2 & 86.6 & 100.8 \\
\hline & SD & 16.2 & 16.3 & 14.4 & 29.3 \\
\hline & SEM & 6.6 & 6.7 & 5.9 & 12.0 \\
\hline
\end{tabular}


table S8. Mean blood pressure ( $\mathrm{mmHg}$ ) from the control and treatment groups in the 120-min rabbit model of arterial thrombosis.

\begin{tabular}{|c|c|c|c|c|c|c|}
\hline Animal ID & Group & BSLN & 0 min & $30 \mathrm{~min}$ & $60 \mathrm{~min}$ & $120 \mathrm{~min}$ \\
\hline 6481 & Control & 39 & 36 & 36 & 35 & 33 \\
\hline 6484 & Control & 44 & 45 & 34 & 33 & 32 \\
\hline 6485 & Control & 38 & NA & 31 & 41 & 41 \\
\hline 5505 & Control & 46 & 44 & 41 & 42 & 33 \\
\hline 5506 & Control & 38 & 46 & 46 & 37 & 36 \\
\hline 5507 & Control & 43 & 37 & 42 & 37 & 41 \\
\hline 6729 & Control & 43 & 41 & 48 & 37 & 47 \\
\hline 6730 & Control & 42 & 35 & 32 & 28 & 27 \\
\hline 6791 & Control & 33 & 40 & 40 & 46 & 63 \\
\hline \multirow[t]{4}{*}{6680} & Control & 37 & 32 & 31 & 29 & 25 \\
\hline & MEAN & 40.3 & 39.6 & 38.1 & 36.5 & 37.8 \\
\hline & SD & 3.9 & 4.9 & 6.2 & 5.6 & 11.1 \\
\hline & SEM & 1.2 & 1.6 & 2.0 & 1.8 & 3.5 \\
\hline 218 & HPMC & 57 & 52 & 47 & 53 & 52 \\
\hline 226 & HPMC & 41 & 49 & 48 & 57 & 46 \\
\hline 6787 & HPMC & 40 & 33 & 37 & 36 & 38 \\
\hline 6702 & HPMC & 34 & 43 & 44 & 35 & 34 \\
\hline 6681 & HPMC & 35 & 31 & 38 & 38 & 47 \\
\hline \multirow[t]{4}{*}{6676} & HPMC & 39 & 44 & 51 & 42 & 35 \\
\hline & MEAN & 41.0 & 42.0 & 44.2 & 43.5 & 42.0 \\
\hline & SD & 8.3 & 8.4 & 5.6 & 9.3 & 7.3 \\
\hline & SEM & 3.4 & 3.4 & 2.3 & 3.8 & 3.0 \\
\hline 5508 & Clopidogrel & 46 & 48 & 60 & 66 & 56 \\
\hline 5651 & Clopidogrel & 43 & 39 & 34 & 34 & 36 \\
\hline 5654 & Clopidogrel & 37 & 36 & 37 & 36 & 35 \\
\hline 5616 & Clopidogrel & 42 & 56 & 55 & 48 & 57 \\
\hline 171 & Clopidogrel & 38 & 39 & 35 & 34 & 49 \\
\hline \multirow[t]{4}{*}{173} & Clopidogrel & 43 & 54 & 54 & 52 & 44 \\
\hline & MEAN & 41.5 & 45.3 & 45.8 & 45.0 & 46.2 \\
\hline & $\mathrm{SD}$ & 3.4 & 8.5 & 11.7 & 12.8 & 9.5 \\
\hline & SEM & 1.4 & 3.5 & 4.8 & 5.2 & 3.9 \\
\hline 5460 & Enoxaparin & 43 & 39 & 31 & 33 & 35 \\
\hline 5461 & Enoxaparin & 38 & 37 & 45 & 32 & 27 \\
\hline 6937 & Enoxaparin & 40 & 29 & 29 & 28 & 32 \\
\hline 6936 & Enoxaparin & 38 & 38 & 38 & 33 & 35 \\
\hline 166 & Enoxaparin & 45 & 42 & 43 & 51 & 53 \\
\hline
\end{tabular}


Submitted Manuscript: Confidential

\begin{tabular}{|c|c|c|c|c|c|c|}
\hline 172 & Enoxaparin & 49 & 47 & 37 & 49 & 52 \\
\hline & MEAN & 42.2 & 38.7 & 37.2 & 37.7 & 39.0 \\
\hline & SD & 4.36 & 5.96 & 6.34 & 9.75 & 10.86 \\
\hline & SEM & 1.8 & 2.4 & 2.6 & 4.0 & 4.4 \\
\hline 5737 & Bivalirudin & 43 & 40 & NA & 43 & 32 \\
\hline 5738 & Bivalirudin & 50 & 44 & 36 & 36 & 39 \\
\hline 164 & Bivalirudin & 42 & 51 & 49 & 57 & 36 \\
\hline 165 & Bivalirudin & 44 & 48 & 46 & 55 & 50 \\
\hline 167 & Bivalirudin & 40 & 49 & 47 & 54 & 55 \\
\hline \multirow[t]{4}{*}{170} & Bivalirudin & 39 & 38 & 42 & 46 & 49 \\
\hline & MEAN & 43.0 & 45.0 & 44.0 & 48.5 & 43.5 \\
\hline & SD & 3.9 & 5.2 & 5.1 & 8.2 & 9.1 \\
\hline & SEM & 1.6 & 2.1 & 2.3 & 3.4 & 3.7 \\
\hline 205 & Ticagrelor & 48 & 58 & 45 & 42 & 39 \\
\hline 206 & Ticagrelor & 44 & 44 & 58 & 42 & 44 \\
\hline 208 & Ticagrelor & 41 & 43 & 43 & 48 & 44 \\
\hline 215 & Ticagrelor & 40 & 47 & 43 & 43 & 38 \\
\hline 217 & Ticagrelor & 46 & 45 & 49 & 44 & 54 \\
\hline \multirow[t]{4}{*}{6788} & Ticagrelor & 38 & 42 & 39 & 38 & 42 \\
\hline & MEAN & 42.8 & 46.5 & 46.2 & 42.8 & 43.5 \\
\hline & SD & 3.8 & 5.9 & 6.6 & 3.3 & 5.7 \\
\hline & SEM & 1.6 & 2.4 & 2.7 & 1.3 & 2.3 \\
\hline 207 & Ticagrelor + Bivalirudin & 38 & 51 & 52 & 56 & 57 \\
\hline 209 & Ticagrelor + Bivalirudin & 39 & 42 & 41 & 40 & 42 \\
\hline 216 & Ticagrelor + Bivalirudin & 58 & 54 & 49 & 47 & 35 \\
\hline 219 & Ticagrelor + Bivalirudin & 40 & 52 & 43 & 47 & 45 \\
\hline 6728 & Ticagrelor + Bivalirudin & 50 & 44 & 46 & 36 & 37 \\
\hline \multirow[t]{4}{*}{6796} & Ticagrelor + Bivalirudin & 35 & 42 & 45 & 37 & 47 \\
\hline & MEAN & 43.3 & 47.5 & 46.0 & 43.8 & 43.8 \\
\hline & SD & 8.8 & 5.4 & 4.0 & 7.6 & 7.9 \\
\hline & SEM & 3.6 & 2.2 & 1.6 & 3.1 & 3.2 \\
\hline 6034 & APT102 & 42 & 33 & 46 & 35 & 31 \\
\hline 6073 & APT102 & 37 & 54 & 50 & 42 & 41 \\
\hline 6074 & APT102 & 38 & 38 & 36 & 38 & 39 \\
\hline 6075 & APT102 & 52 & 50 & 52 & 43 & 41 \\
\hline 130 & APT102 & 59 & 49 & 40 & 52 & 63 \\
\hline \multirow[t]{3}{*}{191} & APT102 & 39 & 39 & 41 & 37 & 54 \\
\hline & MEAN & 44.5 & 43.8 & 44.2 & 41.2 & 44.8 \\
\hline & SD & 9.0 & 8.3 & 6.2 & 6.1 & 11.6 \\
\hline
\end{tabular}


Submitted Manuscript: Confidential

\begin{tabular}{|c|c|c|c|c|c|c|}
\hline & SEM & 3.7 & 3.4 & 2.5 & 2.5 & 4.7 \\
\hline 5736 & APT402 $4 \mu \mathrm{g} / \mathrm{kg} / \mathrm{min}$ & 43 & 43 & 36 & 30 & 30 \\
\hline 5758 & APT402 $4 \mu \mathrm{g} / \mathrm{kg} / \mathrm{min}$ & 51 & 50 & 52 & 52 & 42 \\
\hline 5856 & APT402 $4 \mu \mathrm{g} / \mathrm{kg} / \mathrm{min}$ & 25 & 25 & 24 & 24 & 27 \\
\hline 5857 & APT402 $4 \mu \mathrm{g} / \mathrm{kg} / \mathrm{min}$ & 56 & 52 & 56 & 51 & 53 \\
\hline 6215 & APT402 $4 \mu \mathrm{g} / \mathrm{kg} / \mathrm{min}$ & 44 & NA & 42 & 34 & 36 \\
\hline \multirow[t]{4}{*}{123} & APT402 $4 \mu \mathrm{g} / \mathrm{kg} / \mathrm{min}$ & 45 & 50 & 47 & 49 & 52 \\
\hline & MEAN & 44.0 & 44.0 & 42.8 & 40.0 & 40.0 \\
\hline & SD & 10.5 & 11.2 & 11.6 & 12.1 & 11.0 \\
\hline & SEM & 4.3 & 5.0 & 4.7 & 5.0 & 4.5 \\
\hline 5621 & APT402 $12 \mu \mathrm{g} / \mathrm{kg} / \mathrm{min}$ & 29 & 31 & 32 & 30 & 29 \\
\hline 5622 & APT402 $12 \mu \mathrm{g} / \mathrm{kg} / \mathrm{min}$ & 37 & 35 & 40 & 33 & 33 \\
\hline 5655 & APT402 $12 \mu \mathrm{g} / \mathrm{kg} / \mathrm{min}$ & 51 & 47 & 47 & 42 & 36 \\
\hline 5650 & APT402 $12 \mu \mathrm{g} / \mathrm{kg} / \mathrm{min}$ & 34 & 37 & 37 & 36 & 32 \\
\hline 5858 & APT402 $12 \mu \mathrm{g} / \mathrm{kg} / \mathrm{min}$ & 39 & 35 & 33 & 31 & 33 \\
\hline \multirow[t]{4}{*}{6216} & APT402 $12 \mu \mathrm{g} / \mathrm{kg} / \mathrm{min}$ & 28 & 29 & 26 & 27 & 26 \\
\hline & MEAN & 36.3 & 35.7 & 35.8 & 33.2 & 31.5 \\
\hline & SD & 8.4 & 6.3 & 7.3 & 5.3 & 3.5 \\
\hline & SEM & 3.4 & 2.6 & 3.0 & 2.2 & 1.4 \\
\hline 136 & APT402 $24 \mu \mathrm{g} / \mathrm{kg} / \mathrm{min}$ & 49 & 49 & 48 & 57 & 47 \\
\hline 140 & APT402 $24 \mu \mathrm{g} / \mathrm{kg} / \mathrm{min}$ & 44 & 49 & 72 & 58 & 56 \\
\hline 141 & APT402 $24 \mu \mathrm{g} / \mathrm{kg} / \mathrm{min}$ & 46 & 49 & 49 & 55 & 43 \\
\hline 142 & APT402 $24 \mu \mathrm{g} / \mathrm{kg} / \mathrm{min}$ & 47 & 49 & 47 & 47 & 51 \\
\hline 145 & APT402 $24 \mu \mathrm{g} / \mathrm{kg} / \mathrm{min}$ & 42 & 45 & 41 & 39 & 44 \\
\hline \multirow[t]{4}{*}{163} & APT402 $24 \mu \mathrm{g} / \mathrm{kg} / \mathrm{min}$ & 43 & 58 & 48 & 52 & 38 \\
\hline & MEAN & 45.2 & 49.8 & 50.8 & 51.3 & 46.5 \\
\hline & SD & 2.6 & 4.3 & 10.8 & 7.2 & 6.3 \\
\hline & SEM & 1.1 & 1.8 & 4.4 & 3.0 & 2.6 \\
\hline
\end{tabular}


table S9. Heart rate (bpm) from the control and treatment groups in the 120-min rabbit model of arterial thrombosis. NA: not available.

\begin{tabular}{|c|c|c|c|c|c|c|}
\hline Animal ID & Group & BSLN & 0 min & $30 \mathrm{~min}$ & $60 \mathrm{~min}$ & $120 \mathrm{~min}$ \\
\hline 6481 & Control & NA & NA & NA & NA & NA \\
\hline 6484 & Control & NA & NA & NA & NA & NA \\
\hline 6485 & Control & NA & NA & NA & NA & NA \\
\hline 5505 & Control & 250 & 250 & 246 & 201 & 215 \\
\hline 5506 & Control & 248 & 249 & 250 & 250 & 246 \\
\hline 5507 & Control & 202 & 206 & 203 & 203 & 201 \\
\hline 6729 & Control & 260 & 240 & 240 & 235 & 200 \\
\hline 6730 & Control & 231 & 230 & 218 & 223 & 223 \\
\hline 6791 & Control & 185 & 209 & 209 & 205 & 255 \\
\hline \multirow[t]{4}{*}{6680} & Control & 155 & 140 & 180 & 195 & 195 \\
\hline & MEAN & 218.7 & 217.7 & 220.9 & 216.0 & 219.3 \\
\hline & SD & 39.1 & 38.6 & 25.8 & 20.5 & 23.5 \\
\hline & SEM & 14.8 & 14.6 & 9.7 & 7.7 & 8.9 \\
\hline 218 & HPMC & 250.0 & 251.0 & 208.0 & 250.0 & 252.0 \\
\hline 226 & HPMC & 204.0 & 206.0 & 204.0 & 231.0 & 222.0 \\
\hline 6787 & HPMC & 170 & 231 & 222 & 153 & 242 \\
\hline 6702 & HPMC & 150 & 165 & 165 & 185 & 205 \\
\hline 6681 & HPMC & 220 & 258 & 240 & 255 & 250 \\
\hline \multirow[t]{4}{*}{6676} & HPMC & 212 & 216 & 215 & 198 & 218 \\
\hline & MEAN & 201.0 & 221.2 & 209.0 & 212.0 & 231.5 \\
\hline & SD & 35.9 & 33.9 & 25.0 & 40.1 & 19.2 \\
\hline & SEM & 14.7 & 13.9 & 10.2 & 16.4 & 7.8 \\
\hline 5508 & Clopidogrel & 211 & 200 & 244 & 250 & 250 \\
\hline 5651 & Clopidogrel & 250 & 225 & 194 & 201 & 250 \\
\hline 5654 & Clopidogrel & 150 & 158 & 167 & 169 & 185 \\
\hline 5616 & Clopidogrel & 209 & 201 & 216 & 219 & 222 \\
\hline 171 & Clopidogrel & 200 & 205 & 212 & 222 & 220 \\
\hline \multirow[t]{4}{*}{173} & Clopidogrel & 182 & 202 & 201 & 229 & 242 \\
\hline & MEAN & 200.3 & 198.5 & 205.7 & 215.0 & 228.2 \\
\hline & SD & 33.2 & 21.9 & 25.6 & 27.6 & 25.0 \\
\hline & SEM & 13.6 & 9.0 & 10.4 & 11.3 & 10.2 \\
\hline 5460 & Enoxaparin & NA & NA & NA & NA & NA \\
\hline 5461 & Enoxaparin & NA & NA & NA & NA & NA \\
\hline 6937 & Enoxaparin & NA & NA & NA & NA & NA \\
\hline 6936 & Enoxaparin & NA & NA & NA & NA & NA \\
\hline 166 & Enoxaparin & 235 & 240 & 223 & 210 & 231 \\
\hline 172 & Enoxaparin & 246 & 242 & 248 & 242 & 228 \\
\hline
\end{tabular}


Submitted Manuscript: Confidential

\begin{tabular}{|c|c|c|c|c|c|c|}
\hline & MEAN & 240.5 & 241.0 & 235.5 & 210.0 & 229.5 \\
\hline & SD & 7.78 & 1.41 & 17.68 & 22.63 & 2.12 \\
\hline & SEM & 5.5 & 1.0 & 12.5 & 16.0 & 1.5 \\
\hline 5737 & Bivalirudin & 205 & 225 & 230 & 248 & 248 \\
\hline 5738 & Bivalirudin & 250 & 250 & 250 & 250 & 250 \\
\hline 164 & Bivalirudin & 200 & 205 & 211 & 225 & 250 \\
\hline 165 & Bivalirudin & 171 & 182 & 190 & 193 & 227 \\
\hline 167 & Bivalirudin & 235 & 230 & 229 & 231 & 226 \\
\hline \multirow[t]{4}{*}{170} & Bivalirudin & NA & NA & NA & NA & NA \\
\hline & MEAN & 212.2 & 218.4 & 222.0 & 229.4 & 240.2 \\
\hline & SD & 31.0 & 25.9 & 22.6 & 23.0 & 12.5 \\
\hline & SEM & 13.9 & 11.6 & 10.1 & 10.3 & 5.6 \\
\hline 205 & Ticagrelor & 245.0 & 246.0 & 250.0 & 250.0 & 201.0 \\
\hline 206 & Ticagrelor & 191.0 & 192.0 & 200.0 & 228.0 & 250.0 \\
\hline 208 & Ticagrelor & 250.0 & 219.0 & 242.0 & 244.0 & 250.0 \\
\hline 215 & Ticagrelor & 178.0 & 185.0 & 195.0 & 185.0 & 200.0 \\
\hline 217 & Ticagrelor & 235.0 & 244.0 & 200.0 & 222.0 & 250.0 \\
\hline \multirow[t]{4}{*}{6788} & Ticagrelor & 156.0 & 161.0 & 162.0 & 185.0 & 195.0 \\
\hline & MEAN & 209.2 & 207.8 & 208.2 & 219.0 & 224.3 \\
\hline & $\mathrm{SD}$ & 39.4 & 34.2 & 32.7 & 28.2 & 28.2 \\
\hline & SEM & 16.1 & 14.0 & 13.3 & 11.5 & 11.5 \\
\hline 207 & Ticagrelor + Bivalirudin & 155.0 & 195.0 & 208.0 & 210.0 & 235.0 \\
\hline 209 & Ticagrelor + Bivalirudin & 155.0 & 172.0 & 185.0 & 188.0 & 198.0 \\
\hline 216 & Ticagrelor + Bivalirudin & 202 & 242 & 253 & 210 & 252 \\
\hline 219 & Ticagrelor + Bivalirudin & 244.0 & 250.0 & 250.0 & 250.0 & 250.0 \\
\hline 6728 & Ticagrelor + Bivalirudin & 150.0 & 191.0 & 200.0 & 188.0 & 242.0 \\
\hline \multirow[t]{4}{*}{6796} & Ticagrelor + Bivalirudin & 161.0 & 192.0 & 233.0 & 235.0 & 230.0 \\
\hline & MEAN & 177.8 & 207.0 & 221.5 & 213.5 & 234.5 \\
\hline & SD & 37.6 & 31.4 & 28.0 & 25.0 & 19.8 \\
\hline & SEM & 15.3 & 12.8 & 11.4 & 10.2 & 8.1 \\
\hline 6034 & APT102 & 229 & 230 & 210 & NA & NA \\
\hline 6073 & APT102 & 171 & 161 & 190 & 176 & 180 \\
\hline 6074 & APT102 & 182 & 171 & 165 & 162 & 161 \\
\hline 6075 & APT102 & 250 & 250 & 225 & 202 & 220 \\
\hline 130 & APT102 & 215 & 208 & 220 & 208 & 248 \\
\hline \multirow[t]{4}{*}{191} & APT102 & 250 & 250 & 250 & 250 & NA \\
\hline & MEAN & 216.2 & 211.7 & 210.0 & 199.6 & 202.3 \\
\hline & $\mathrm{SD}$ & 33.7 & 38.8 & 29.5 & 33.9 & 39.2 \\
\hline & SEM & 13.7 & 15.8 & 12.0 & 13.8 & 17.5 \\
\hline
\end{tabular}


Submitted Manuscript: Confidential

\begin{tabular}{|c|c|c|c|c|c|c|}
\hline 5736 & APT402 $4 \mu \mathrm{g} / \mathrm{kg} / \mathrm{min}$ & 230 & 230 & 230 & 242 & NA \\
\hline 5758 & APT402 $4 \mu \mathrm{g} / \mathrm{kg} / \mathrm{min}$ & 250 & 250 & 250 & 250 & NA \\
\hline 5856 & APT402 $4 \mu \mathrm{g} / \mathrm{kg} / \mathrm{min}$ & 250 & 250 & 250 & 250 & 250 \\
\hline 5857 & APT402 $4 \mu \mathrm{g} / \mathrm{kg} / \mathrm{min}$ & 250 & 250 & 250 & 250 & 250 \\
\hline 6215 & APT402 $4 \mu \mathrm{g} / \mathrm{kg} / \mathrm{min}$ & 248 & 250 & 250 & 250 & 250 \\
\hline \multirow[t]{4}{*}{123} & APT402 $4 \mu \mathrm{g} / \mathrm{kg} / \mathrm{min}$ & 230 & 242 & 240 & 200 & 250 \\
\hline & MEAN & 243.0 & 245.3 & 245.0 & 240.3 & 250.0 \\
\hline & $\mathrm{SD}$ & 10.1 & 8.2 & 8.4 & 20.0 & 0.0 \\
\hline & SEM & 4.1 & 3.3 & 3.4 & 8.2 & 0.0 \\
\hline 5621 & APT402 $12 \mu \mathrm{g} / \mathrm{kg} / \mathrm{min}$ & 195 & 201 & 202 & 224 & 241 \\
\hline 5622 & APT402 $12 \mu \mathrm{g} / \mathrm{kg} / \mathrm{min}$ & 208 & 211 & 217 & 210 & 219 \\
\hline 5655 & APT402 $12 \mu \mathrm{g} / \mathrm{kg} / \mathrm{min}$ & 230 & 228 & 227 & 241 & 244 \\
\hline 5650 & APT402 $12 \mu \mathrm{g} / \mathrm{kg} / \mathrm{min}$ & 156 & 180 & 190 & 200 & 210 \\
\hline 5858 & APT402 $12 \mu \mathrm{g} / \mathrm{kg} / \mathrm{min}$ & 211 & 239 & 239 & 240 & NA \\
\hline \multirow[t]{4}{*}{6216} & APT402 $12 \mu \mathrm{g} / \mathrm{kg} / \mathrm{min}$ & 192 & 194 & 196 & 190 & NA \\
\hline & MEAN & 198.7 & 208.8 & 211.8 & 217.5 & 228.5 \\
\hline & SD & 24.9 & 21.9 & 19.1 & 21.1 & 16.6 \\
\hline & SEM & 10.2 & 8.9 & 7.8 & 8.6 & 8.3 \\
\hline 136 & APT402 $24 \mu \mathrm{g} / \mathrm{kg} / \mathrm{min}$ & 242 & 245 & 245 & 230 & 232 \\
\hline 140 & APT402 $24 \mu \mathrm{g} / \mathrm{kg} / \mathrm{min}$ & 222 & 245 & 225 & 275 & 280 \\
\hline 141 & APT402 $24 \mu \mathrm{g} / \mathrm{kg} / \mathrm{min}$ & 224 & 227 & 231 & 229 & 230 \\
\hline 142 & APT402 $24 \mu \mathrm{g} / \mathrm{kg} / \mathrm{min}$ & 205 & 234 & 231 & 223 & 211 \\
\hline 145 & APT402 $24 \mu \mathrm{g} / \mathrm{kg} / \mathrm{min}$ & 242 & NA & 245 & 225 & 230 \\
\hline \multirow[t]{4}{*}{163} & APT402 $24 \mu \mathrm{g} / \mathrm{kg} / \mathrm{min}$ & 230 & 235 & 230 & 230 & 230 \\
\hline & MEAN & 227.5 & 237.2 & 234.5 & 235.3 & 235.5 \\
\hline & SD & 14.0 & 7.8 & 8.4 & 19.6 & 23.2 \\
\hline & SEM & 5.7 & 3.5 & 3.4 & 8.0 & 9.5 \\
\hline
\end{tabular}


table S10. Bleeding time in healthy mice treated with APT402 at $0.2 \mathrm{mg} / \mathrm{kg}$ IP followed by $48 \mathrm{~h} \mathrm{SC}$ infusion at $1.5 \mu \mathrm{g} / \mathrm{kg} / \mathrm{min}$ or enoxaparin at 6 $\mathrm{mg} / \mathrm{kg} /$ day. NA: not available.

\begin{tabular}{|c|c|c|}
\hline Animal ID & Group & Bleeding Time (sec) \\
\hline A1 & Control & 61 \\
\hline $\mathrm{A} 2$ & Control & 87 \\
\hline A3 & Control & 61 \\
\hline L14 & Control & 75 \\
\hline L15 & Control & 72 \\
\hline \multirow[t]{4}{*}{ L16 } & Control & 73 \\
\hline & MEAN & 71.5 \\
\hline & SD & 9.8 \\
\hline & SEM & 4.0 \\
\hline A14 & APT402 (24h) & 43 \\
\hline A15 & APT402 (24h) & 51 \\
\hline A16 & APT402 (24h) & NA \\
\hline A17 & APT402 (24h) & 81 \\
\hline A18 & APT402 (24h) & 50 \\
\hline A19 & APT402 (24h) & 48 \\
\hline A 20 & APT402 (24h) & 47 \\
\hline A 21 & APT402 (24h) & 41 \\
\hline \multirow[t]{4}{*}{$\mathrm{A} 22$} & APT402 (24h) & 53 \\
\hline & MEAN & 51.8 \\
\hline & SD & 12.5 \\
\hline & SEM & 4.4 \\
\hline A4 & APT402 (48h) & 53 \\
\hline A5 & APT402 (48h) & 59 \\
\hline A6 & APT402 (48h) & 70 \\
\hline A7 & APT402 (48h) & 55 \\
\hline A 8 & APT402 (48h) & 67 \\
\hline A9 & APT402 (48h) & 63 \\
\hline A10 & APT402 (48h) & 66 \\
\hline A11 & APT402 (48h) & 63 \\
\hline A12 & APT402 (48h) & 55 \\
\hline \multirow[t]{4}{*}{$\mathrm{A} 13$} & APT402 (48h) & 62 \\
\hline & MEAN & 61.3 \\
\hline & $\mathrm{SD}$ & 5.7 \\
\hline & SEM & 1.8 \\
\hline A24 & APT402 (72h) & 47 \\
\hline A25 & APT402 (72h) & 52 \\
\hline A26 & APT402 (72h) & 38 \\
\hline $\mathrm{A} 27$ & APT402 (72h) & 85 \\
\hline A28 & APT402 (72h) & 54 \\
\hline
\end{tabular}




\begin{tabular}{|c|c|c|}
\hline A29 & APT402 (72h) & 64 \\
\hline A30 & APT402 (72h) & 48 \\
\hline A31 & APT402 (72h) & 34 \\
\hline A32 & APT402 (72h) & 66 \\
\hline \multirow[t]{4}{*}{ A33 } & APT402 (72h) & 51 \\
\hline & MEAN & 53.9 \\
\hline & SD & 14.8 \\
\hline & SEM & 4.7 \\
\hline L7 & Enoxaparin (24h) & 114 \\
\hline L8 & Enoxaparin (24h) & 360 \\
\hline L9 & Enoxaparin (24h) & 145 \\
\hline \multirow[t]{4}{*}{$\mathrm{L} 10$} & Enoxaparin (24h) & 81 \\
\hline & MEAN & 175.0 \\
\hline & SD & 126.1 \\
\hline & SEM & 63.0 \\
\hline L4 & Enoxaparin (48h) & 185 \\
\hline L5 & Enoxaparin (48h) & 176 \\
\hline \multirow[t]{4}{*}{ L6 } & Enoxaparin (48h) & 366 \\
\hline & MEAN & 242.3 \\
\hline & $\mathrm{SD}$ & 107.2 \\
\hline & SEM & 61.9 \\
\hline L11 & Enoxaparin (72h) & 327 \\
\hline L12 & Enoxaparin (72h) & 183 \\
\hline L13 & Enoxaparin (72h) & 102 \\
\hline L17 & Enoxaparin (72h) & 360 \\
\hline L18 & Enoxaparin (72h) & 159 \\
\hline \multirow[t]{4}{*}{ L19 } & Enoxaparin (72h) & 360 \\
\hline & MEAN & 248.5 \\
\hline & $\mathrm{SD}$ & 113.8 \\
\hline & SEM & 46.5 \\
\hline
\end{tabular}


table S11. Activated partial thromboplastin time in healthy mice treated with APT402 at $0.2 \mathrm{mg} / \mathrm{kg}$ IP followed by $48 \mathrm{~h} \mathrm{SC}$ infusion at $1.5 \mu \mathrm{g} / \mathrm{kg} / \mathrm{min}$ or enoxaparin at $6 \mathrm{mg} / \mathrm{kg} /$ day.NA: not available.

\begin{tabular}{|c|c|c|}
\hline Animal ID & Group & aPTT (sec) \\
\hline A1 & Control & 46.5 \\
\hline $\mathrm{A} 2$ & Control & 37.3 \\
\hline $\mathrm{A} 3$ & Control & 20.95 \\
\hline L14 & Control & 28.2 \\
\hline L15 & Control & 32.45 \\
\hline \multirow[t]{4}{*}{ L16 } & Control & 24.5 \\
\hline & MEAN & 31.65 \\
\hline & $\mathrm{SD}$ & 9.28 \\
\hline & SEM & 3.79 \\
\hline A14 & APT402 (24h) & 35.25 \\
\hline A15 & APT402 (24h) & 40.25 \\
\hline A16 & APT402 (24h) & 27.5 \\
\hline A17 & APT402 (24h) & 26.95 \\
\hline A18 & APT402 (24h) & 32.5 \\
\hline A19 & APT402 (24h) & 22.45 \\
\hline A 20 & APT402 (24h) & 28.2 \\
\hline A 21 & APT402 (24h) & 25.45 \\
\hline \multirow[t]{4}{*}{ A22 } & APT402 (24h) & 28.95 \\
\hline & MEAN & 29.72 \\
\hline & $\mathrm{SD}$ & 5.43 \\
\hline & SEM & 1.81 \\
\hline A4 & APT402 (48h) & 42.5 \\
\hline A5 & APT402 (48h) & 30.95 \\
\hline A6 & APT402 (48h) & NA \\
\hline A7 & APT402 (48h) & 21.05 \\
\hline A8 & APT402 (48h) & 39.7 \\
\hline A9 & APT402 (48h) & 35.7 \\
\hline A 10 & APT402 (48h) & 29.75 \\
\hline A11 & APT402 (48h) & 24.2 \\
\hline A12 & APT402 (48h) & 24.2 \\
\hline \multirow[t]{4}{*}{ A13 } & APT402 (48h) & 49.45 \\
\hline & MEAN & 33.06 \\
\hline & $\mathrm{SD}$ & 9.52 \\
\hline & SEM & 3.17 \\
\hline A24 & APT402 (72h) & 30.75 \\
\hline A25 & APT402 (72h) & 30.95 \\
\hline A26 & APT402 (72h) & NA \\
\hline A 27 & APT402 (72h) & 22.95 \\
\hline A28 & APT402 (72h) & 20.95 \\
\hline
\end{tabular}




\begin{tabular}{|c|c|c|}
\hline A29 & APT402 (72h) & 26.7 \\
\hline $\mathrm{A} 30$ & APT402 (72h) & 19.7 \\
\hline A31 & APT402 (72h) & 17.2 \\
\hline A32 & APT402 (72h) & 22.25 \\
\hline \multirow[t]{4}{*}{ A33 } & APT402 (72h) & 20.7 \\
\hline & MEAN & 23.57 \\
\hline & SD & 4.86 \\
\hline & SEM & 1.62 \\
\hline L7 & Enoxaparin (24h) & 100 \\
\hline L8 & Enoxaparin (24h) & NA \\
\hline L9 & Enoxaparin (24h) & 100 \\
\hline \multirow[t]{4}{*}{ L10 } & Enoxaparin (24h) & 100 \\
\hline & MEAN & 100 \\
\hline & SD & 0 \\
\hline & SEM & 0 \\
\hline L4 & Enoxaparin (48h) & 100 \\
\hline L5 & Enoxaparin (48h) & 100 \\
\hline \multirow[t]{4}{*}{ L6 } & Enoxaparin (48h) & 92.9 \\
\hline & AVG & 97.63 \\
\hline & STDV & 4.10 \\
\hline & SEM & 2.37 \\
\hline L11 & Enoxaparin (72h) & NA \\
\hline L12 & Enoxaparin (72h) & 100 \\
\hline L13 & Enoxaparin (72h) & 100 \\
\hline L17 & Enoxaparin (72h) & 100 \\
\hline L18 & Enoxaparin (72h) & 100 \\
\hline \multirow[t]{4}{*}{ L19 } & Enoxaparin (72h) & 100 \\
\hline & MEAN & 100 \\
\hline & $\mathrm{SD}$ & 0 \\
\hline & SEM & 0 \\
\hline
\end{tabular}


table S12. Complete blood count data from mice after treatment with APT 402 at $0.2 \mathrm{mg} / \mathrm{kg}$ IP followed by $48 \mathrm{~h} \mathrm{SC}$ infusion at $1.5 \mu \mathrm{g} / \mathrm{kg} / \mathrm{min}$ or enoxaparin at 6 $\mathrm{mg} / \mathrm{kg} / \mathrm{day}$.

\begin{tabular}{|c|c|c|c|c|c|c|c|c|c|c|c|}
\hline Animal ID & Group & NE \% & LY \% & МO \% & EО \% & ВА \% & $\begin{array}{c}\text { RBC } \\
(\mathrm{M} / \mathrm{uL}) \\
\end{array}$ & $\begin{array}{c}\text { HB } \\
(\mathrm{g} / \mathrm{dL}) \\
\end{array}$ & НСТ \% & $\begin{array}{c}\text { PLT } \\
(\mathrm{K} / \mathbf{u L}) \\
\end{array}$ & $\begin{array}{c}\text { MPV } \\
(f L)\end{array}$ \\
\hline A1 & Control & 23.6 & 74.6 & 1.5 & 0.2 & 0.1 & 9.4 & 13.2 & 43.0 & 1141 & 4.2 \\
\hline $\mathrm{A} 2$ & Control & 20.9 & 76.7 & 2.2 & 0.2 & 0.0 & 9.6 & 13.1 & 43.0 & 1111 & 4.3 \\
\hline A3 & Control & 23.8 & 74.1 & 1.5 & 0.4 & 0.2 & 9.9 & 13.4 & 44.6 & 1126 & 4.2 \\
\hline L14 & Control & 13.7 & 81.4 & 4.7 & 0.2 & 0.0 & 10.1 & 13.7 & 47.4 & 856 & 4.1 \\
\hline L15 & Control & 24.3 & 73.9 & 1.4 & 0.4 & 0.0 & 9.7 & 13.6 & 44.1 & 1127 & 4.6 \\
\hline \multirow[t]{4}{*}{ L16 } & Control & 26.9 & 70.3 & 2.6 & 0.3 & 0.0 & 9.7 & 13.1 & 43.9 & 1015 & 4.4 \\
\hline & MEAN & 22.20 & 75.15 & 2.32 & 0.29 & 0.04 & 9.74 & 13.35 & 44.33 & 1062.67 & 4.30 \\
\hline & SD & 4.56 & 3.69 & 1.26 & 0.09 & 0.06 & 0.24 & 0.26 & 1.63 & 111.00 & 0.18 \\
\hline & SEM & 1.86 & 1.50 & 0.51 & 0.04 & 0.02 & 0.10 & 0.11 & 0.67 & 45.32 & 0.07 \\
\hline A14 & APT402 (24h) & 24.6 & 73.9 & 1.2 & 0.3 & 0.0 & 9.2 & 12.8 & 42.2 & 982 & 4.0 \\
\hline A15 & APT402 (24h) & 20.3 & 78.5 & 1.2 & 0.1 & 0.0 & 9.1 & 13.1 & 42.8 & 912 & 4.3 \\
\hline A16 & APT402 (24h) & 22.2 & 75.8 & 2.0 & 0.0 & 0.0 & 9.4 & 12.7 & 42.2 & 1016 & 4.2 \\
\hline A17 & APT402 (24h) & 35.1 & 63.2 & 1.3 & 0.3 & 0.1 & 9.7 & 13.9 & 44.7 & 1165 & 4.3 \\
\hline A18 & APT402 (24h) & 27.3 & 70.6 & 1.9 & 0.3 & 0.0 & 9.6 & 13.3 & 43.9 & 830 & 3.9 \\
\hline A19 & APT402 (24h) & 24.6 & 72.8 & 2.0 & 0.6 & 0.0 & 9.5 & 13.2 & 43.9 & 1080 & 4.4 \\
\hline $\mathrm{A} 20$ & APT402 (24h) & 21.0 & 77.1 & 0.9 & 0.7 & 0.2 & 9.6 & 13.3 & 43.4 & 973 & 4.2 \\
\hline A21 & APT402 (24h) & 23.1 & 74.8 & 2.0 & 0.0 & 0.1 & 9.4 & 13.0 & 44.1 & 1140 & 4.2 \\
\hline \multirow[t]{4}{*}{$\mathrm{A} 22$} & APT402 (24h) & 21.7 & 76.3 & 1.7 & 0.1 & 0.1 & 9.2 & 12.6 & 42.1 & 1030 & 4.2 \\
\hline & MEAN & 24.44 & 73.66 & 1.57 & 0.27 & 0.06 & 9.42 & 13.10 & 43.26 & 1014.22 & 4.19 \\
\hline & SD & 4.54 & 4.58 & 0.43 & 0.26 & 0.07 & 0.22 & 0.39 & 0.96 & 106.22 & 0.15 \\
\hline & SEM & 1.51 & 1.53 & 0.14 & 0.09 & 0.02 & 0.07 & 0.13 & 0.32 & 35.41 & 0.05 \\
\hline A4 & APT402 (48h) & 23.1 & 74.1 & 2.2 & 0.5 & 0.1 & 9.5 & 13.7 & 42.6 & 1063 & 4.2 \\
\hline A5 & APT402 (48h) & 17.9 & 79.9 & 1.7 & 0.4 & 0.1 & 9.8 & 13.6 & 45.5 & 973 & 4.0 \\
\hline A6 & APT402 (48h) & 35.1 & 62.2 & 2.0 & 0.7 & 0.0 & 8.4 & 12.3 & 38.4 & 1356 & 4.8 \\
\hline A7 & APT402 (48h) & 42.3 & 55.4 & 1.9 & 0.4 & 0.0 & 10.0 & 13.3 & 41.9 & 1268 & 4.0 \\
\hline A8 & APT402 (48h) & 25.6 & 72.9 & 1.4 & 0.1 & 0.0 & 9.5 & 13.4 & 42.6 & 1085 & 4.2 \\
\hline A9 & APT402 (48h) & 19.4 & 79.1 & 1.5 & 0.0 & 0.0 & 9.5 & 13.5 & 42.2 & 1103 & 4.4 \\
\hline A10 & APT402 (48h) & 24.8 & 73.5 & 1.4 & 0.3 & 0.0 & 9.1 & 13.2 & 40.3 & 1014 & 4.1 \\
\hline A11 & APT402 (48h) & 20.2 & 77.7 & 1.7 & 0.4 & 0.0 & 9.5 & 13.4 & 42.6 & 1005 & 4.1 \\
\hline
\end{tabular}




\begin{tabular}{|c|c|c|c|c|c|c|c|c|c|c|c|}
\hline A12 & APT402 (48h) & 21.1 & 77.5 & 1.0 & 0.4 & 0.1 & 9.7 & 13.2 & 44.0 & 1071 & 3.9 \\
\hline \multirow[t]{4}{*}{ A13 } & APT402 (48h) & 28.5 & 69.4 & 1.9 & 0.2 & 0.0 & 9.1 & 12.6 & 39.9 & 777 & 4.2 \\
\hline & MEAN & 25.80 & 72.17 & 1.65 & 0.35 & 0.03 & 9.40 & 13.22 & 42.00 & 1071.50 & 4.19 \\
\hline & SD & 7.67 & 7.91 & 0.36 & 0.20 & 0.03 & 0.46 & 0.44 & 2.05 & 158.10 & 0.26 \\
\hline & SEM & 2.43 & 2.50 & 0.11 & 0.06 & 0.01 & 0.15 & 0.14 & 0.65 & 50.00 & 0.08 \\
\hline A24 & APT402 (72h) & 27.0 & 71.8 & 1.2 & 0.1 & 0.0 & 10.3 & 13.8 & 47.0 & 983 & 4.1 \\
\hline A25 & APT402 (72h) & 17.7 & 80.1 & 1.5 & 0.4 & 0.2 & 10.1 & 14.0 & 44.9 & 990 & 4.1 \\
\hline A26 & APT402 (72h) & 20.7 & 75.2 & 3.6 & 0.5 & 0.1 & 10.1 & 13.5 & 46.2 & 1086 & 4.3 \\
\hline A27 & APT402 (72h) & 16.7 & 81.4 & 1.3 & 0.4 & 0.2 & 9.9 & 13.8 & 45.4 & 575 & 4.0 \\
\hline A28 & APT402 (72h) & 18.1 & 80.4 & 1.5 & 0.0 & 0.0 & 9.6 & 13.4 & 42.0 & 728 & 4.1 \\
\hline A29 & APT402 (72h) & 23.1 & 75.0 & 1.7 & 0.2 & 0.0 & 9.1 & 12.8 & 41.2 & 1075 & 4.1 \\
\hline $\mathrm{A} 30$ & APT402 (72h) & 25.7 & 72.8 & 1.4 & 0.1 & 0.0 & 9.2 & 12.4 & 38.5 & 775 & 4.4 \\
\hline A31 & APT402 (72h) & 18.3 & 78.7 & 2.8 & 0.1 & 0.0 & 9.8 & 13.5 & 44.8 & 734 & 4.1 \\
\hline A32 & APT402 (72h) & 36.4 & 62.3 & 0.8 & 0.5 & 0.1 & 9.0 & 12.7 & 39.9 & 951 & 4.5 \\
\hline \multirow[t]{4}{*}{ A33 } & APT402 (72h) & 23.4 & 75.3 & 0.8 & 0.4 & 0.2 & 9.5 & 13.2 & 42.6 & 841 & 4.1 \\
\hline & MEAN & 22.70 & 75.31 & 1.66 & 0.25 & 0.08 & 9.66 & 13.31 & 43.25 & 873.80 & 4.18 \\
\hline & SD & 5.96 & 5.65 & 0.87 & 0.17 & 0.09 & 0.44 & 0.53 & 2.84 & 169.25 & 0.16 \\
\hline & SEM & 1.88 & 1.79 & 0.28 & 0.05 & 0.03 & 0.14 & 0.17 & 0.90 & 53.52 & 0.05 \\
\hline L7 & Enoxaparin (24h) & 13.3 & 84.7 & 2.0 & 0.1 & 0.0 & 10.1 & 13.6 & 49.1 & 1099 & 4.4 \\
\hline L8 & Enoxaparin (24h) & 13.2 & 84.6 & 1.4 & 0.7 & 0.0 & 9.7 & 13.9 & 45.0 & 980 & 4.4 \\
\hline L9 & Enoxaparin (24h) & 14.1 & 84.4 & 1.3 & 0.2 & 0.0 & 9.6 & 13.5 & 44.4 & 1127 & 4.5 \\
\hline \multirow[t]{4}{*}{ L10 } & Enoxaparin (24h) & 12.7 & 83.6 & 3.6 & 0.2 & 0.0 & 10.0 & 13.8 & 44.4 & 838 & 4.0 \\
\hline & MEAN & 13.32 & 84.29 & 2.07 & 0.30 & 0.01 & 9.84 & 13.70 & 45.73 & 1011.00 & 4.33 \\
\hline & SD & 0.59 & 0.49 & 1.02 & 0.29 & 0.01 & 0.22 & 0.18 & 2.27 & 131.77 & 0.22 \\
\hline & SEM & 0.29 & 0.25 & 0.51 & 0.15 & 0.00 & 0.11 & 0.09 & 1.13 & 65.89 & 0.11 \\
\hline L4 & Enoxaparin (48h) & 25.8 & 72.3 & 1.8 & 0.0 & 0.0 & 9.7 & 13.0 & 45.0 & 1004 & 3.9 \\
\hline L5 & Enoxaparin (48h) & 14.7 & 83.3 & 1.9 & 0.1 & 0.0 & 9.0 & 12.1 & 42.3 & 860 & 4.1 \\
\hline \multirow[t]{4}{*}{ L6 } & Enoxaparin (48h) & 17.4 & 81.3 & 1.1 & 0.2 & 0.0 & 9.6 & 13.3 & 44.3 & 965 & 4.3 \\
\hline & MEAN & 19.29 & 78.99 & 1.62 & 0.09 & 0.01 & 9.44 & 12.80 & 43.87 & 943.00 & 4.10 \\
\hline & SD & 5.81 & 5.85 & 0.45 & 0.12 & 0.01 & 0.40 & 0.62 & 1.40 & 74.48 & 0.20 \\
\hline & SEM & 3.35 & 3.38 & 0.26 & 0.07 & 0.01 & 0.23 & 0.36 & 0.81 & 43.00 & 0.12 \\
\hline
\end{tabular}


Submitted Manuscript: Confidential

\begin{tabular}{|c|c|c|c|c|c|c|c|c|c|c|c|}
\hline L11 & Enoxaparin (72h) & NB & NB & NB & NB & NB & NB & NB & NB & NB & NB \\
\hline L12 & Enoxaparin $(72 h)$ & 8.5 & 88.2 & 3.3 & 0.0 & 0.0 & 10.6 & 14.9 & 49.6 & 1004 & 4.1 \\
\hline L13 & Enoxaparin (72h) & 11.8 & 86.3 & 1.8 & 0.1 & 0.0 & 10.4 & 14.6 & 47.4 & 1010 & 4.0 \\
\hline L17 & Enoxaparin (72h) & 12.0 & 86.5 & 1.5 & 0.0 & 0.0 & 9.7 & 13.7 & 45.4 & 999 & 4.2 \\
\hline L18 & Enoxaparin (72h) & 15.6 & 81.1 & 2.2 & 1.1 & 0.1 & 9.6 & 13.5 & 45.6 & 931 & 4.1 \\
\hline \multirow[t]{4}{*}{ L19 } & Enoxaparin $(72 \mathrm{~h})$ & 14.3 & 83.7 & 1.8 & 0.2 & 0.0 & 9.7 & 13.9 & 46.9 & 1034 & 4.1 \\
\hline & MEAN & 12.44 & 85.14 & 2.10 & 0.28 & 0.04 & 9.98 & 14.12 & 46.98 & 995.60 & 4.10 \\
\hline & SD & 2.73 & 2.78 & 0.73 & 0.43 & 0.06 & 0.47 & 0.60 & 1.69 & 38.53 & 0.07 \\
\hline & SEM & 1.22 & 1.24 & 0.32 & 0.19 & 0.03 & 0.21 & 0.27 & 0.76 & 17.23 & 0.03 \\
\hline
\end{tabular}


table S13. Thrombus weights from the control and treatment groups in the murine model of venous thrombosis. APT402-LD: low dose infusion at $0.5 \mu \mathrm{g} / \mathrm{kg} / \mathrm{min}$ IP; APT402-HD: high dose infusion at $1.5 \mu \mathrm{g} / \mathrm{kg} / \mathrm{min} \mathrm{SC}$.

\begin{tabular}{|c|c|}
\hline Group & Thrombus weight (g) \\
\hline CONTROL & 0.0274 \\
\hline CONTROL & 0.0241 \\
\hline CONTROL & 0.0242 \\
\hline CONTROL & 0.0271 \\
\hline CONTROL & 0.0251 \\
\hline CONTROL & 0.0263 \\
\hline CONTROL & 0.0270 \\
\hline CONTROL & 0.0268 \\
\hline MEAN & 0.0260 \\
\hline $\mathrm{SD}$ & 0.0013 \\
\hline SEM & 0.0005 \\
\hline Enoxaparin & 0.0169 \\
\hline Enoxaparin & 0.0043 \\
\hline Enoxaparin & 0.0049 \\
\hline Enoxaparin & 0.0062 \\
\hline Enoxaparin & 0.0043 \\
\hline Enoxaparin & 0.0074 \\
\hline Enoxaparin & 0.0068 \\
\hline Enoxaparin & 0.0292 \\
\hline Enoxaparin & 0.0064 \\
\hline MEAN & 0.0096 \\
\hline $\mathrm{SD}$ & 0.0083 \\
\hline SEM & 0.0028 \\
\hline APT402-LD & 0.0264 \\
\hline APT402-LD & 0.0069 \\
\hline APT402-LD & 0.0228 \\
\hline APT402-LD & 0.0106 \\
\hline APT402-LD & 0.0120 \\
\hline APT402-LD & 0.0105 \\
\hline APT402-LD & 0.0192 \\
\hline APT402-LD & 0.0196 \\
\hline APT402-LD & 0.0107 \\
\hline APT402-LD & 0.0096 \\
\hline MEAN & 0.0148 \\
\hline SD & 0.0066 \\
\hline SEM & 0.0021 \\
\hline APT402-HD & 0.0090 \\
\hline
\end{tabular}




\begin{tabular}{cl} 
APT402-HD & 0.0059 \\
APT402-HD & 0.0096 \\
APT402-HD & 0.0094 \\
APT402-HD & 0.0104 \\
APT402-HD & 0.0133 \\
APT402-HD & 0.0081 \\
APT402-HD & 0.0074 \\
APT402-HD & 0.0081 \\
\hline MEAN & 0.0090 \\
SD & 0.0021 \\
SEM & 0.0007 \\
\hline
\end{tabular}


table S14. Bleeding time from the control and treatment groups in the murine model of venous thrombosis. APT402-LD: low dose infusion at $0.5 \mu \mathrm{g} / \mathrm{kg} / \mathrm{min}$ IP; APT402-HD: high dose infusion at $1.5 \mu \mathrm{g} / \mathrm{kg} / \mathrm{min}$ SC. NA: not available.

5

\begin{tabular}{|c|c|}
\hline Group & Bleeding time (sec) \\
\hline CONTROL & 50 \\
\hline CONTROL & 50 \\
\hline CONTROL & 45 \\
\hline CONTROL & 45 \\
\hline CONTROL & 50 \\
\hline CONTROL & 50 \\
\hline CONTROL & 40 \\
\hline CONTROL & 93 \\
\hline MEAN & 52.9 \\
\hline SD & 16.6 \\
\hline SEM & 5.9 \\
\hline Enoxaparin & NA \\
\hline Enoxaparin & 94 \\
\hline Enoxaparin & 92 \\
\hline Enoxaparin & 600 \\
\hline Enoxaparin & 130 \\
\hline Enoxaparin & 350 \\
\hline Enoxaparin & 290 \\
\hline Enoxaparin & 193 \\
\hline Enoxaparin & 371 \\
\hline MEAN & 265.0 \\
\hline $\mathrm{SD}$ & 174.8 \\
\hline SEM & 61.8 \\
\hline APT402-LD & 57 \\
\hline APT402-LD & 61 \\
\hline APT402-LD & 64 \\
\hline APT402-LD & 45 \\
\hline APT402-LD & 45 \\
\hline APT402-LD & 64 \\
\hline APT402-LD & 50 \\
\hline APT402-LD & 70 \\
\hline APT402-LD & 64 \\
\hline APT402-LD & 190 \\
\hline MEAN & 71.0 \\
\hline $\mathrm{SD}$ & 42.7 \\
\hline SEM & 13.5 \\
\hline APT402-HD & 88 \\
\hline
\end{tabular}




\begin{tabular}{cc} 
APT402-HD & 53 \\
APT402-HD & 59 \\
APT402-HD & 25 \\
APT402-HD & 70 \\
APT402-HD & 72 \\
APT402-HD & 68 \\
APT402-HD & 50 \\
APT402-HD & 63 \\
\hline MEAN & 60.9 \\
SD & 17.6 \\
SEM & 5.9 \\
\hline
\end{tabular}


table S15. Activated partial thromboplastin time from the control and treatment groups in the murine model of venous thrombosis. APT402-LD: low dose infusion at $0.5 \mu \mathrm{g} / \mathrm{kg} / \mathrm{min}$ IP; APT402-HD: high dose infusion at $1.5 \mu \mathrm{g} / \mathrm{kg} / \mathrm{min}$ SC. aPTT measurement ceiling was set for 100 seconds. NA: not available.

\begin{tabular}{|c|c|}
\hline Group & aPTT (sec) \\
\hline CONTROL & 28.8 \\
\hline CONTROL & 27.0 \\
\hline CONTROL & 34.0 \\
\hline CONTROL & 31.7 \\
\hline CONTROL & 28.8 \\
\hline CONTROL & 27.0 \\
\hline CONTROL & 34.0 \\
\hline CONTROL & 29.0 \\
\hline MEAN & 30.0 \\
\hline SD & 2.8 \\
\hline SEM & 1.0 \\
\hline Enoxaparin & NA \\
\hline Enoxaparin & 63.7 \\
\hline Enoxaparin & 53.2 \\
\hline Enoxaparin & 59.0 \\
\hline Enoxaparin & 39.5 \\
\hline Enoxaparin & 41.7 \\
\hline Enoxaparin & 100 \\
\hline Enoxaparin & 100 \\
\hline Enoxaparin & 100 \\
\hline MEAN & 69.6 \\
\hline SD & 26.4 \\
\hline SEM & 9.3 \\
\hline APT402-LD & 24.5 \\
\hline APT402-LD & NA \\
\hline APT402-LD & 26.5 \\
\hline APT402-LD & 33.7 \\
\hline APT402-LD & 27.7 \\
\hline APT402-LD & NA \\
\hline APT402-LD & 30.7 \\
\hline APT402-LD & 30.1 \\
\hline APT402-LD & NA \\
\hline APT402-LD & NA \\
\hline MEAN & 28.9 \\
\hline SD & 3.3 \\
\hline SEM & 1.3 \\
\hline
\end{tabular}




\begin{tabular}{cc}
\hline APT402-HD & NA \\
APT402-HD & 32.5 \\
APT402-HD & 40.5 \\
APT402-HD & 33.5 \\
APT402-HD & 34.2 \\
APT402-HD & 33.2 \\
APT402-HD & 37.2 \\
APT402-HD & 35.2 \\
APT402-HD & 37.2 \\
\hline MEAN & 35.4 \\
SD & 21.7 \\
SEM & 7.2 \\
\hline
\end{tabular}


table S16. Thrombin clotting time from the control and treatment groups in the murine model of venous thrombosis. APT402-LD: low dose infusion at $0.5 \mu \mathrm{g} / \mathrm{kg} / \mathrm{min}$ IP; APT402-HD: high dose infusion at $1.5 \mathrm{mg} / \mathrm{kg} / \mathrm{min}$ SC. NA: not available.

5

\begin{tabular}{|c|c|}
\hline Group & Thrombin clotting time (sec) \\
\hline CONTROL & 12.0 \\
\hline CONTROL & 12.0 \\
\hline CONTROL & 12.7 \\
\hline CONTROL & 12.0 \\
\hline CONTROL & 12.0 \\
\hline CONTROL & 12.0 \\
\hline CONTROL & 12.7 \\
\hline CONTROL & 13.0 \\
\hline MEAN & 12.3 \\
\hline SD & 0.4 \\
\hline SEM & 0.2 \\
\hline Enoxaparin & 18.3 \\
\hline Enoxaparin & 27.6 \\
\hline Enoxaparin & 20.6 \\
\hline Enoxaparin & 18.5 \\
\hline Enoxaparin & 13.2 \\
\hline Enoxaparin & 15.8 \\
\hline Enoxaparin & 41.5 \\
\hline Enoxaparin & 33.9 \\
\hline Enoxaparin & NA \\
\hline MEAN & 23.7 \\
\hline $\mathrm{SD}$ & 9.8 \\
\hline SEM & 3.5 \\
\hline APT402-LD & 12.7 \\
\hline APT402-LD & 11.7 \\
\hline APT402-LD & 13.5 \\
\hline APT402-LD & 13.2 \\
\hline APT402-LD & 14.3 \\
\hline APT402-LD & 13.8 \\
\hline APT402-LD & NA \\
\hline APT402-LD & 11.8 \\
\hline APT402-LD & 12.7 \\
\hline APT402-LD & NA \\
\hline MEAN & 13.0 \\
\hline $\mathrm{SD}$ & 0.9 \\
\hline SEM & 0.3 \\
\hline APT402-HD & 22.1 \\
\hline
\end{tabular}




\begin{tabular}{cc} 
APT402-HD & 14.0 \\
APT402-HD & 12.7 \\
APT402-HD & 13.5 \\
APT402-HD & 12.2 \\
APT402-HD & 12.2 \\
APT402-HD & 12.2 \\
APT402-HD & 12.0 \\
APT402-HD & 12.2 \\
\hline MEAN & 13.7 \\
SD & 3.2 \\
SEM & 1.1 \\
\hline
\end{tabular}

